\title{
Silent, no more: The 1974 Kanawha County textbook controversy and the rise of conservatism in America
}

Justin J. McHenry

West Virginia University

Follow this and additional works at: https://researchrepository.wvu.edu/etd

\section{Recommended Citation}

McHenry, Justin J., "Silent, no more: The 1974 Kanawha County textbook controversy and the rise of conservatism in America" (2006). Graduate Theses, Dissertations, and Problem Reports. 696.

https://researchrepository.wvu.edu/etd/696

This Thesis is protected by copyright and/or related rights. It has been brought to you by the The Research Repository @ WVU with permission from the rights-holder(s). You are free to use this Thesis in any way that is permitted by the copyright and related rights legislation that applies to your use. For other uses you must obtain permission from the rights-holder(s) directly, unless additional rights are indicated by a Creative Commons license in the record and/ or on the work itself. This Thesis has been accepted for inclusion in WVU Graduate Theses, Dissertations, and Problem Reports collection by an authorized administrator of The Research Repository @ WVU. For more information, please contact researchrepository@mail.wvu.edu. 


\title{
Silent, No More:
}

The 1974 Kanawha County Textbook Controversy and the Rise of Conservatism in America

\section{Justin J. McHenry}

\author{
Thesis submitted to the \\ Eberly College of Arts and Sciences \\ at West Virginia University \\ in partial fulfillment of the requirements \\ for the degree of
}

\author{
Master of Arts \\ in \\ History
}

Elizabeth Fones-Wolf, Ph.D., Chair

Kenneth Fones-Wolf, Ph.D.

Barbara Rasmussen, Ph.D.

Department of History

Morgantown, West Virginia

2006

Keywords: Kanawha County, West Virginia, Conservatism, White Backlash, New Right Copyright 2006 Justin J. McHenry 


\section{Abstract \\ Silent, No More: \\ The 1974 Kanawha County Textbook Controversy and the Rise of Conservatism in America}

\section{Justin J. McHenry}

Silent, No More explores the 1974 Kanawha County textbook controversy, and places it within the context of the rise of conservatism in America. This rise can be seen in the upsurge of grassroots, community activism in the seventies, the White Backlash associated with the campaigns of George Wallace, the New Right, and the New Christian Right. The thesis shows how the Kanawha County protestors' words and actions paralleled that of aforementioned conservative movements, creating, in the end, one of the first manifestations of a single-issue conservative uprising in the seventies. 


\section{Contents}

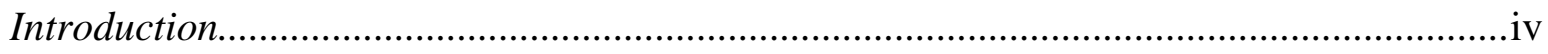

Chapter One: The Kanawha County Textbook Controversy: What Went Down....................1

Chapter Two: Literature Review............................................................................ 15

Chapter Three: The Roots Are Going to Holler: Grassroots Activism..................................25

Chapter Four: America Without Tears: Backlash Politics...............................................45

Chapter Five: The Searchers: Building the New Right..................................................73

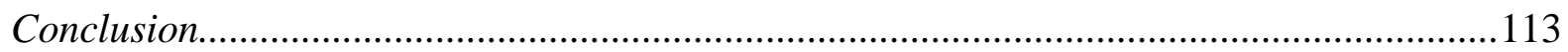

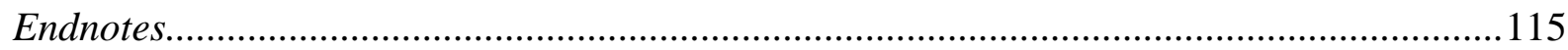

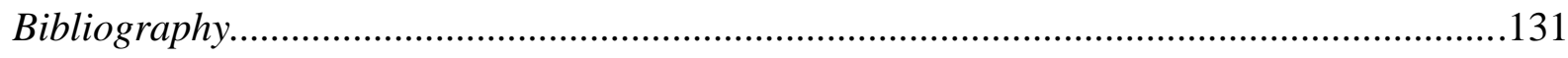




\section{Introduction}

It was on a rainy night in June, when the situation hit critical mass. Hundreds of people poured out of the small school board auditorium and onto Elizabeth Street, peering above and through the mass of umbrellas. They waited to see the fate of their children. In the auditorium, a anti-textbook speaker stood, said his or her piece over a sprinkling of amens and yeah's from the crowd, and sat back down. A pro-text speaker rose, tried to say his or her piece only to be forcibly shouted down with catcalls of “communist” and, for some strange reason, “Time! Time!” On that night, Nixon’s so-called silent majority crept out of their cocoon.

For much of 1974, Kanawha County, West Virginia, seethed with tension, tensions originating from the adoption by the county school board of some language arts textbooks. What started out with textbooks quickly turned into something else, something bigger. Textbooks were no longer at stake but rather the children, the future, America. The debate shifted somewhere along the way toward a new vision of America, a vision dripping with the traditions of the past, coming at the intersection of a country poised to change direction.

A new kind of conservatism - social conservatism gained a new ascendancy in the 1970s. In general, the nation experienced a move toward the right during the "Me Decade.” The events of the decade have been described as a backlash against the radicalism of the 1960s, a decade fraught with uncomfortable changes for many, changes brought about by the civil rights movement, which openly confronted segregated America and forced the country to accept all men as equals. While federal and state statutes forbade formal discrimination, they could not 
make people change their attitudes about race. Some grew weary of the gains made by AfricanAmericans. Some saw Johnson’s Great Society geared only towards African-American poverty and not meeting the needs of white, working poor. George Wallace would tap into this growing resentment with his impressive showings in the presidential elections of 1968 and 1972. Other movements such as the women's liberation and gay rights exposed new ideas to new parts of the world.

Grass roots conservative skirmishes popped up all around the country like the textbook controversy in Kanawha County and the anti-busing conflict in Boston. A new kind of populism began to emerge - a kind of direct democracy that mated mistrust of large institutions, both public and private, with traditions and group identities based on religious background, ethnic ties, and family relations. Conservative Christians took advantage of this and pitched America's religious pluralist state to the right, as they began to mobilize politically. The sheer combined force of their numbers and outspokenness exerted enormous pressure on the elitist institutions they saw at the heart of the degradation of America.

The New Right appeared on this conservative precipice, and quickly exerted itself as the most dynamic force on the American political scene. Its leaders saw an avenue to power - a way to change America’s vision. The liberal idealism of the 1960s cold cocked traditional family values, and by the 1970s there were more than enough issues for the New Right to exploit like the Equal Rights Amendment and feminism, drug use, pornography, school books and curriculum, busing, affirmative action, Roe v. Wade, and gay rights. They built upon these issues by appealing to the social conservatism of traditionally Democratic or politically independent constituencies, “Conservatism cannot become the dominant political force in America,” direct 
mail guru Richard Viguerie claims, "until we stress the issues of concern to ethnic and bluecollar Americans, born again Christians, pro-life Catholics and Jew. Some of these are busing, pornography, education, traditional Biblical moral values and quotas.”1

Early in the New Right game, the textbook controversy provided a catalyst for the burgeoning movement - a way to add more fodder to the notion that a change needed to come. The parents of Kanawha County rebelled at a unique moment in the seventies, occurring at the nexus of America's growing conservatism. The backlash, the new populism, the rise of the New Right, and the New Christian Right, all were present in some form or another during that year, 1974, in Kanawha County. This thesis will examine the ascension of conservatism through the spectrum of the Kanawha County textbook controversy.

Chapter one will explore what happened during the controversy and provide some background to the educational system in Kanawha County before 1974. The second chapter is devoted to the initial response of the controversy by the national media, as well as, a literature review of what has been written so far on the textbook controversy. Chapter three will take a look at grassroots activism in the seventies and in Appalachia and will try and place the textbook controversy in the middle of these events. Chapter four will go into some detail about the complaints of the protestors, primarily the charges that the textbooks were anti-American, antiChristian, and communist. These complaints will be linked with the larger backlash against the social movements of the sixties. The final chapter will deal with the political rise of the New Right and how it used events like the textbook controversy to gain influence and power in America. It will also chronicle the activities of the groups and people associated with the New Right in Kanawha County. 
Throughout this thesis, the term protestor is used to describe any person who spoke negatively of the textbooks and any person who participated in any school boycott, mass meeting, demonstration, march, etc. When the term protestor is used in the context of describing attitudes of the individuals against the textbooks, like in relation to the White Backlash and religious attitudes, this is not meant to suggest that all of these individuals expressed or held these attitudes of beliefs. It is only meant to suggest that these attitudes and beliefs were present in some of the individuals and not all.

This is all done with the hope of better understanding this one event and this one place, but also to demonstrate how a relatively small and powerless group can impact the nation and how the nation impacts their lives and attitudes. This thesis is about the protestors and their words and actions, and only veers away to show a larger context to their words and actions. The protestors exhibited trends that would pave the way for future single-issue interest groups to garner the attention and respect that they do. From Supreme Court nominee battles to Terry Schiavo, conservative activists owe a debt of gratitude to the parents of Kanawha County. 


\section{Chapter One}

\section{The Kanawha County Textbook Controversy: What Went Down}

Like most things, the textbook controversy didn't occur in a vacuum. It was the sum of a lot of decisions made prior to 1974. School consolidation heads a long list of actions that parents disagreed with in the years leading up to the textbook controversy. The school system evolved from small, one-room community centers to complex bureaucracies, turning the cornerstone of the community into a hive of professionals and middle-class values. The school and teacher became removed entities with the parents left somewhat absent from the educative process. Kanawha County encountered a rash of over fifty school closings in the decade prior to the textbook controversy. Schools located in rural areas suffered heavily from population loss and from an attempt by county officials to upgrade the quality of schools, resulting in the closing of many community schools. ${ }^{1}$ The National Education Association in its report on the textbook controversy concluded, "The way in which the consolidations were effected - without adequately involving the communities concerned - did nothing to improve the quality of school-community relations. The loss of their small community schools and the feeling that their interests had been ignored throughout the consolidation process, testimony suggested, have contributed to a longsimmering resentment against school officials on the part of rural citizens."2

In a precursor to the textbook controversy, parents groused over the topic of sex education during the 1969-1970 school year. In 1969, the School Health Education Study (SHES) selected Kanawha County to pilot a kindergarten through twelfth grade health and 
family living program. The Kanawha County Curriculum Advisory Council, composed of eleven citizens and school personnel, and the Kanawha County Board of Education both signed off on the program. The '69-'70 school year saw four elementary, two junior and two high schools integrate the SHES program into their curriculum.

Immediately forces gathered in opposition led by outspoken housewife Alice Moore. The events eerily mirrored those of the textbook controversy - from Moore’s leadership to the numerous groups that organized around the issue (Citizens for Parents’ Action Committee, Mothers Organized for Moral Stability, and the Movement to Restore Decency Committee), their labeling the SHES material as anti-Christian, anti-American, and immoral, and Moore made claims the material advanced secular humanist beliefs. She defeated incumbent Dr. Carl Tully in May 1970 to gain a seat on the Kanawha County Board of Education from where she launched an attack on language arts textbooks four years later.

The Kanawha County Curriculum Council played an important role prior to the textbook controversy in advising the Board of Education on the direction of curriculum changes. Created during the 1964-65 school year, the Council studied and made recommendations concerning curriculum. The eleven community representatives were recommended and appointed and didn't represent a cross-section of Kanawha County's population. Often, council members came from the well-educated, middle and upper classes, those who had the spare time to devote to the Council. Throughout the early 1970s, the Board of Education made several changes to the Council like adding more professional educators, when the Council disbanded before the start of the 1973-74 school year, Kanawha County lost its only organized vehicle for community input on textbook matters. ${ }^{3}$ 
West Virginia law mandates that the selection of textbooks occur on a five-year cyclical rotation, where every five years new textbooks are chosen for a specific subject. In 1974, the subject happened to be language arts textbooks; the following year new history textbooks were selected, and so on. The West Virginia Board of Education states:

The West Virginia Board of Education recognizes the pluralistic nature of American society, and minority and ethnic group contributions are an inextricable part of the total growth and development of this nation.... Education must perpetuate these contributions as an essential part of the American Heritage.... Much of the instructional program is based on or derived from factual and conceptual material contained in textbooks and other printed materials. Therefore be it resolved that both state and local textbook committee and individual educators charged with responsibility for the selection of textbooks and other printed materials to be used in the school programs K-12 shall select only those textbooks and materials for classroom use which accurately portray minority and ethnic group contributions to American growth and culture and which depict and illustrate the inter-cultural character of our pluralistic society. ${ }^{4}$

James Moffett, director of the Interaction textbook program, one of the controversial textbook series, commented on his books, "The program was conspicuous for its unusually rich array of diverse subjects, media, and methods. The point of this multiplicity was to ensure that any background, level of development, temperament, or interest could find plenty of ways to engage with and develop language.”5 The textbooks selection committee chose these textbooks, because they met the qualifications laid out by the state, and many found the textbooks to be of great quality, "I personally found many of them quite appealing - the sorts of books I would like my two children to study.,

The state required that basic elementary textbooks must be chosen from a preapproved list created by the West Virginia Board of Education. Secondary and supplemental text adoption fell onto the shoulders of professional educators - teachers. The average citizen was out of luck 
when it came to trying to have their say in the whole process. ${ }^{7}$ The language arts adoption process began in September of 1973, with educators forming a Curriculum Study Committee to review all the texts and related instructional material. They were instructed by State Superintendent of Schools, Dr. Daniel B. Taylor, to make sure the textbooks answered the following questions:

1) Does the content of the textbooks and related materials, for all grade levels, clearly indicate, where relevant, that the United States is a multi-ethnic nation?

2) Are the viewpoints, attitudes, values, and contributions of various minority and ethnic groups portrayed in relationship to - a) the formulation of American institutions (e.g. family, church, school, courts, etc.) b) the dynamic nature of American society (past and present) c) the various processes of communication within and among groups.

3) Do the pictorial illustrations, where relevant, reflect the intercultural character of our pluralistic society?

4) Does the content assist students in examining their own self image? ${ }^{8}$

The board achieved its goal as the protestors would fault the texts for following all of these guidelines and some.

The textbook committee presented its recommendations on March 14, 1974. A special room housed the texts for board members to review the books - none ever did. Additional arrangements were made for the public to view the language arts textbooks at the Kanawha County Public Library, but few took advantage.

April 11, 1974, marked the beginning of the controversy. On that day, the Kanawha County Board of Education voted to adopt the language arts textbooks as recommended by the Textbook Selection Committee over the objections of board member Alice Moore, who opposed the limited amount of time the Board and the public had to review the books. She succeeded in 
changing the wording of the adoption motion, so that objectionable material could be deleted at a later date.

Moore is an interesting character. Later on when the controversy really intensified, the textbook protestors would turn her into something of a folk hero. Those opposed to her gave her the nickname - “Sweet Alice,” which her followers gleefully adopted for themselves. The wife of a St. Albans' Church of Christ minister, Moore served on the board for four quiet years after the sex education row in `69- 70 . Something differentiated Moore from most other women in Kanawha County. She was politically savvy. She played her femininity to her advantage. Her voice carried authority like that of a refined Southern lady, with no hint of country twang to undermine the aura she gave off. At meetings, a barrage of accusations flooded out of Moore at the other board members not waiting or wanting, for that matter, to hear any rebuttals. She browbeat Ivy-League educated men into silence with not only the force of her will but the sheer surprise that such words could vehemently flow from such a sweet woman. Moore played an important role in the transformation of conservative women. Carol Mason believes Moore’s impact could be felt nationwide, “As a feminist, I see how 'Sweet Alice' was disdained as someone who, not unlike the feminists of the time, was breaking the rules of traditional femininity.” As a persona, Sweet Alice personifies the shift that Christian conservative women were making in the 1970s. She broke with the passivity of femininity and Christian humility; in the process, she helped shape a discursive strategy that distinguished the New Right from the old right."9

After that April meeting, Moore went on a small speaking tour of area churches to drum up opposition to the textbooks. In May, school board elections were held with two seats up for 
grabs: Matthew Kinsolving and Board President, Albert Anson, Jr. Kinsolving (postmaster of Belle and a two-term incumbent) emphasized greater two-way communication within the school system and the initiation of competitive bidding on major school system purchases. Anson stressed his twenty-two years of experience on the Board and supported the major school programs in Kanawha County. The main challenger, F. Douglas Stump of Elkview, favored initiation of competitive bidding and neighborhood schools. Stump positioned himself as the anti-establishment candidate, which to most people's surprise proved effective. He received the most votes by nearly 4,000 with Kinsolving coming in second and Anson in third. Anson's term would expire in January. Only one candidate campaigned on textbooks - Rev. Charles Meadows of the Mount Pleasant Baptist Church - but his objections were not against language arts textbooks but against the teaching of evolution. ${ }^{10}$

A Daily-Mail editorial foreshadowed much of the loss of authority sentiment of the protestors, "As school patrons and taxpayers hope to retain any control over the education of their children and the expenditure of public funds, they cannot consent to this erosion of their authority. Once they do, the character and quality of public education pass to other interests who, whatever their cause and programs, need not respond at all to the public interest." ${ }^{11}$ On May 23, the Board held a special meeting dominated by short tempers and hot debate. Thelma Conley, Secondary English Consultant for Kanawha County schools, spoke on behalf of the Textbook Selection Committee’s saying America was a complex society made up of people who had a multitude of different values, views and opinions. The school system has a responsibility to reflect those holding values, views and opinions other than those of the white, middle class. She argued that the curriculum should include in its language arts programs written works that 
reflected the diversity of opinion that was typically American by providing vivid, real-life pictures of our nation, the world and its people through the eyes of individual authors. It was not the schools job to indoctrinate but to provide the student with a base for them to make their own decisions. Alice Moore countered by calling the books, "trashy, filthy, and too one-sided.” She felt the texts presented only a black point of view and nothing representing the white, middleclass values. "I’m not asking for something anti-black," she said, "but we have got to have something from both sides. I want to see something patriotic in those books." ${ }^{\text {12 }}$ Basically all the debates and arguments between pro and anti text forces followed along these same lines for the remainder of the controversy. Some might have rearticulated or rephrased, but they did not stray too far from this script.

The public began to take notice, helped along by a series of editorials aired on WCHS Television early in June. The importance of these editorials cannot be underestimated, for the six editorials (repeated on the six and eleven o'clock news) were watched by 90,000 households out of a population of 153,000 households for the early news and an additional 60,000 households for the late news. WCHS brought the textbooks to the attention of all of Kanawha County. ${ }^{13}$ The editorials criticized the manner in which the texts were selected and recommended more citizen input. More time was needed they said for the public to review the books, though they found the material to be well rounded. Also, they read selections from the textbooks over the air, exposing many to the content for the first time. Now that the cat leapt out of the bag, people began formulating their own ideas and opinions about the textbooks - the most vocal of which came from those in opposition to the textbooks. The PTA came out against the books. A group of area religious leaders released a statement in support of the texts. Tension grew throughout June over 
the upcoming board meeting on June 27, which would decide if the textbooks would be purchased or not.

The rain came out of the west that night, and for four hours the faithful stood in it, listening through open doors and windows to the proceedings going on inside of the School Board auditorium. But inside the storm raged on. The meeting devolved into three-way shouting match between the audience, the speaker, and Sweet Alice. As much as Moore huffed, she could not stop the board from buying all but eight of the over three hundred textbooks. The board voted three to two in favor of the texts (Board members Albert Anson, Jr., Harry A. Stansbury, and Russell Isaacs voted for with Matthew Kinsolving and Moore voting against).

With this defeat, those against the textbooks recognized more needed to be done if they wanted to prevail. Slowly over the remaining summer months of seventy-four, a grass roots movement developed. Communities began forming organizations to combat the textbooks. One calling itself the Christian-American Parents released a statement to the press stating they hoped to "restore traditional American values to our public school system so that our children will have a decent community and world to live in."14 They held a rally on August 2, where its president, Harold Roberts, declared, "We who furnish the money were finally made aware that we have no voice in favor of the textbooks have insulted us....By adoption of these books they have admitted that West Virginia has low moral standards." ${ }^{\text {15 }}$ Roberts laid it all out on the table - the feelings of estrangement with the government, isolation, and moral outrage. The government had no business working against parental authority it did. If the politicians they elected would not listen, then they would make them listen. More demonstrations were planned, marches on the capitol, and picketing, whatever it took to force their point and the get the books away from their 
children. Pickets stalked outside of all the valley’s Heck’s, West Virginia’s precursor to WalMart, where Board member Isaacs served as president, in an attempt to force Isaacs to switch his vote. Christian-American picketers stationed themselves outside of the Governor's mansion, trying in vain to gain his ear, his support.

Another protest group organized, calling itself Concerned Citizens. Before the start of the school year, Concerned Citizens held two separate rallies in St. Albans and Campbells Creek that drew hundreds of people at both venues. More revival than rally, shouts of "Amen, brother” quickly followed any denouncement of those "filthy" textbooks. ${ }^{16}$ In the fervor, those in attendance pledged to boycott the opening of the new school year on September 3. The protestors now readied themselves for the intensification of the conflict. Nobody else did, accounting for why the controversy exploded like it did. Most of the school board, the county, the state, and the white collar elite of Kanawha County failed to take the protestors' grievances or their threats seriously. When the protestors made good on them, a proper response from the authorities never surfaced, and the battle slogged on into the fall and the beginning of winter. The school year began on the Tuesday after Labor Day. Nearly 20 percent of the fortyfive thousand students enrolled in Kanawha County schools did not go to class that Tuesday. The western half of the county reported near normal attendance, while the Upper Kanawha Valley, around Campbells Creek and Cabin Creek, experienced considerable absenteeism. At Alum Creek Elementary School protestors would not allow buses to let the children off in front of the school. Eighty-five demonstrators stood outside of Midway Elementary in Campbells Creek. They cheered and applauded when a nearly empty school bus pulled up. Sheriff's deputies cleared paths for the students, teachers, and buses to make their way to some school. ${ }^{17}$ 
Wednesday morning the miners joined in on the boycott, when they refused to cross the picket line of the textbook protestors. All the mines of Kanawha and some in Boone and Fayette counties shut down, affecting more than forty-five hundred workers. Some of the miners expressing sympathy with the protestors joined the picket lines outside of other area businesses and industries. They began picketing several school bus garages, successfully keeping many buses from making their morning runs. Miners also showed up at the Kroger at Belle and Walker Machinery Co. The pickets affected customer flow and about a hundred employees did not report to work at Walker that day. Sympathy might have kept the miners out a day or so, but they stayed out of the mines for different reasons most likely. The United Mine Workers contract expired in November, and many have speculated during and after the controversy that the miners went out to lower the stockpiles, increasing their bargaining power. ${ }^{18}$

Moore remained active, lending her support to the protestors: "Where else are they to go and what are they to do? One thousand people stood in the rain during a board meeting and saw the book adopted anyway. What can they do?”19 Then, the arrests began. Three were arrested at a bus terminal in Sissonville. Ten women were held in contempt of court. Most of the action took place in the Upper Kanawha Valley - the eastern part of the county. But a concerted effort was put in place to bring the fight to Charleston and the western half of the county. "I suspect by the middle of next week we'll have the West Side shut down. But I want to say I never instigated this. This book is a controversial thing. People have called me by the hundreds telling me the west end of the county is next. We'll shut it all the way to Putnam County,” head of Concerned Citizens, Rev. Marvin Horan, part-time preacher and part-time truck driver, predicted. ${ }^{20}$ During the first couple of weeks of the school year, protestors succeeded in stopping all 
of Charleston's bus services and a lot of the county's school buses from making their routes by picketing bus terminuses and threatening violence. Hundreds kept daily watch outside of the School Board offices, while more worked area businesses like Union Carbide, John Amos Power Plant, Du Pont’s Belle works, and Walker Machinery, effectively halting operations temporarily. The pressure paid off. The Board of Education agreed to submit the disputed textbooks to a committee appointed by the Board for review. Also, the Board removed all supplemental texts plus the Galaxy and D.C. Heath Series. Sounding somewhat defeated the Board's announcement read, “All books have been moved from the classrooms." ${ }^{21}$ This was the board’s first concession. Later that evening, September 11, at Watt Powell Park, a thousand protestors rejected the Board's offer. Horan changed his mind about the whole deal, thinking he could get more concessions from the Board: “The people agreed that they aren’t going to allow their children to go to school until the books are taken out for good, with out a moratorium. As far as we're concerned, the boycott is $100 \%$ on." ${ }^{22}$ Following the rejection, violence broke out in isolated incidents around the county. Protestors hurled rocks at a plant at Cabin Creek. Smashed windows at a truck company at Belle. Fighting took place outside of a Kroger warehouse in Kanawha City; threats on school buses canceled runs in the Upper Kanawha Valley. A man was grazed by a bullet, and another was severely beaten at the Smith Transfer Company in Belle. ${ }^{23}$

As the violence increased, so did the confusion. Squabbling amongst Sheriff Kemp Melton and the State Police angered many citizens. Governor Arch Moore consistently refused to get involved or send in the State Police to quell the unrest. Hundreds of callers fearful for their property and life saturated the Capitol switchboard pleading for police protection. They were told, "We're sorry it’s a county problem., ${ }^{24}$ Confusion swarmed around the Valley. "No one 
really seems to know what to do,” wrote one woman: “People are really afraid especially up at the other end of the valley.... Sheriff Melton, Governor Moore, and Mayor Hutchinson are all fighting about who is not providing police protection.”25

Friday, September 13, County School Superintendent Dr. Kenneth Underwood decided to close all county schools due to the lack of law and order; that same morning shots rang out at a UPS Depot in Rand critically wounding a UPS driver. This rapid fire set of events led Horan to rethink his earlier refusal of the Board's offer, and he subsequently called for all protesters to withdraw and go back to work. ${ }^{26}$

The initial wave of violence subsided, and the pickets gradually withered away, though rallies and marches still absorbed much of Charleston. By September 20, the start of the review committee, the people seemed willing to allow the committee to do its job. Throughout the start of October, the protestors regrouped by holding a fund-raising telethon and a large rally at WattPowell Park. Terror once again gripped Kanawha County as dynamite rocked a Cabin Creek elementary school and a firebombing at another elementary school at Campbells Creek on October 9. The rest of October witnessed two more firebombings of local elementary schools, gunshots fired through the window of Overbrook Elementary school, the dynamiting of another Campbells Creek school, all culminating with the dynamiting of the Board of Education building. School attendance kept creeping lower and lower, and the rallies grew larger and larger, fueled by the review committee's recommendation to adopt nearly all of the textbooks in early November. A week later, the board voted four to one to return the books to the classrooms. $^{27}$

In November, the extremist protestors changed tactics away from bombings towards 
stopping the school buses. Rifle and shotgun blasts plugged a half dozen buses, which were only occupied by the drivers, and more protestors began threatening parents to keep their children out of school. Things so deteriorated that Gov. Moore was forced to act, finally calling in the State Police to assist the Sheriff and his deputies in restoring peace. With the aid of the State Police, tensions abated, and life appeared normal for the first time all school year. ${ }^{28}$ The Board placed the supplemental texts in the library only to be accessed with parental approval, and they passed new guidelines for future textbook adoptions:

Textbooks must not intrude into the privacy of students' homes by asking personal questions about interfeelings or behavior of themselves or their parents or encourage them to criticize their parents by direct question, statement, or inference. Textbooks must recognize the sanctity of the home and emphasize its importance as the basic unit of American society.

Textbooks must not contain offensive language.

Textbooks must teach the true history and heritage of the United States and of any other countries studied in the curriculum. They must not defame our nation's founders or misrepresent the ideals and causes for which they struggled and sacrificed.

Textbooks used in the study of English language shall teach that traditional rules of grammar are a worthwhile subject for academic pursuit and are essential for effective communication among English-speaking people.

Textbooks shall encourage loyalty to the United States and the several states and emphasize the responsibilities of citizenship and the obligation to redress grievances through legal processes. They must not encourage sedition or revolution against our government or teach or imply that an alien form of government. ${ }^{29}$

It would appear to be a victory for the anti-textbook protestors. The Board responded favorably to all the objections raised by the protestors. The guidelines had to be a bitter pill for the Board to pass, since the original intent of the textbooks was to foster multi-cultural understanding. The 
noble effort to expose the children to different attitudes, races, beliefs, and cultures failed. While tragic that might be, the protestors did not have the good sense to recognize the gains they won. (It should be said that only a very small portion of the protestors were bomb wielding, guns a-blazing crazies, who managed to single-handedly isolate most of their middleto upper-class support.) Protestors now centered their attention on establishing private schools, where they could teach their children in the firm tradition of godly, Christian inhibitions. "It seemed like a bunch of kids playing school,” Shirley A. Smith succinctly put it. ${ }^{30}$ Smith worked for the Kanawha County Public Library and had to make frequent visits to these new, upstart schools, and her impressions take you to a place of dirt and disorder. "There was an air of absolute hostility about the place,” Smith says of Faith Gospel Tabernacle School: “They seemed

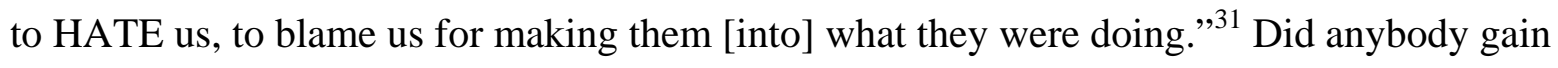
anything other than futility? 


\section{Chapter Two}

\section{Literature Review}

The literature on the textbook controversy, while not vast, is diverse and covers the controversy from nearly every aspect - from educational to social. As the events unfolded, the national media responded by sending in their reporters. Their coverage tended to be extremely condescending. To the media, the controversy signified nothing. It was an anomaly, the result of a bunch of uppity yokels. They dismissed the protestors' grievances as the fruition of some backwards culture: "[You] enter a part of the nation skipped over indeed... that skipped over part of the [Lower] Kanawha Valley has the blunted and grotesque aspect of the southeastern corner of Georgia that James Dickey described in Deliverance.” Academics at the time focused more on the educational consequences. By viewing the textbook controversy in this light, many limited their scope of the clash in Kanawha County, failing to see this not as a localized event, but as one event in a much larger cloudburst of conservative uprisings.

Most in the liberal media tried to understand the protestors but few moved beyond condescension. They strove to explain the textbook controversy, some more successful than others. The Progressive talked of a cultural war in America, "[The textbook controversy] is in part a class war, a cultural war, a religious war. It is a struggle for power and authority that has sundered a peaceful community into rigid and fearful factions. And it is a complex and profoundly disturbing reflection of the deep fissures that crisscross American society.” The media relied heavily on stereotypes like violent hillbillies, "It should not be too surprising that 
the controversy over textbooks has long passed the point of reasonable people in disagreement,”3 or common perceptions of Appalachians, “[Alice Moore’s] tone alternated between Andy Griffith-like wonder and fundamentalist wrath.”4 The New Yorker promoted the idea that class warfare had broken out in Kanawha County and violence was a given: "The need for solidarity means that an unauthorized strike in a place like West Virginia almost has to lead to violence...there is an assumption that any dispute involving mountain people - particularly mountain people who are miners - will end in violence...the ordinary way of talking about disputes in Kanawha County is to talk about violence."5

Writing for the Nation, Curtis Seltzer gave one of the most balanced reports and explanations of the textbook controversy, most likely due to his experience in the area. He was able to empathize with both sides: "Lack of control is really the source of the discontent. Logically, pluralism - of the kind promoted in the texts - should accept a community of fundamentalists or coal miners, just as readily as communities of blacks, native Americans, and European ethnics. Whether such pluralism works in practice, say in Kanawha County, is of course another question.”6

While the left was too busy condemning and stereotyping, the conservative, rightist media wrote lengthy tracts praising the protestors without question. The John Birch Society organ, American Opinion, spoke of the growing discontent throughout the country: "If you listen you can hear it: The low, angry whispering like a moan from a bassoon. The attack on Middle America has cut through the fat to the bone, and a vast giant is stirring, muttering, angry with unnamable frustrations, and looking for leadership.”7 The Citizen, which had close ties to the Ku Klux Klan, lashed out against the "mongrelization” of the races the textbooks promoted and 
hailed the protestors for their actions: "From the growing recognition throughout America that they are fighting for a righteous cause, the parents of Kanawha County, West Virginia, are bound to be inspired in their determination to continue their crusade until victory is won.”8

Shortly after the bulk of the tension died down late in 1974, a number of individuals began writing on the subject. The National Education Association released their findings in February of 1975 from a series of hearings they held that past December. The report entitled Kanawha County, West Virginia: A Textbook Study in Cultural Conflict covered a number of topics including the cultural and educational background of rural Appalachia, and it painted a sorrowful canvas of the overall education consequences the textbook controversy would have on education. Three dissertations dealing in part with the educational side of the controversy were also written. Carl L. Holland studied the effects the controversy had on school counselors, and Don J. Goode mapped the values and attitudes of those involved in the textbook battle. Catherine Ann Candor produced the only history of the textbook controversy, giving a day-by-day account of what occurred over a year-long period from April 1974 to 1975.

What these previous works failed to produce was a credible reason for why the textbook controversy took place. The most fundamental question underlying the whole controversy is "why?” Why did such a passive segment of the population rise up in mass? Why then? Why there? The research on the textbook controversy coming out of the late seventies untill today primarily focuses on why. Two sets of sociologists debated the origins of the textbook controversy through academic journals in the late 1970s, and John Gaventa wrote an important work, Power and Powerlessness, around the same time that suggests a different approach to why rebellion occurred. Understanding why the people acted the way that they did allows for a better 
analysis of the controversy, as well as the conservative movement.

Ann L. Page and Donald A. Clelland were the first to explore the reasons behind the protestors' actions. Page and Clelland claim the protestors reacted out of a loss of control over their way of life. They see the controversy as a lifestyle issue, as an indicator for developing status group consciousness representing a 'vertical cleavage' in the status arrangements between 'cultural fundamentalists' and 'cultural modernists' that cuts across economic and educational class or strata lines. ${ }^{9}$

Poverty did not play a role, since the poor were not at the core of the movement. Working class ministers provided the heart of the protestors, Page and Clelland argue. Also, the movement was not a substitute for class action on the part of the working class. A variety of sources, the educational system, mass media, government, and the churches, threatened the protestors' lifestyle and world view, compelling them into action. They had no control over every socialization agency that affected their lives. In an attempt to build and sustain a moral order that provided the basic meaning for human lives, they lashed out. They protested. ${ }^{10}$

Dwight Billings and Robert Goldman refute Page and Clelland's politics of lifestyle. They claim Page and Clelland were negligent in removing the controversy from its social structure, its grounding in social history, and from its related cultural meaning. To know anything about the textbook controversy, one needs to look at and understand the tradition of working class resistance in the area. The roots of miner discontent runs deep throughout the Upper Kanawha Valley. Ignoring this past would be like dismissing the whole thing. ${ }^{11}$ Billings and Goldman describe the controversy as an "episode of working class opposition obscured by a language more often used by other classes for social control to evoke 
commitment and stability rather than dissent." ${ }^{„ 12}$ Kanawha County families rebelled against school authority in the name of Appalachian working-class culture, which includes Evangelical Protestantism. Evangelicalism, rather than being a dynamic force in shaping the protest, simply provided a common language for resistance. Billings and Goldman explained that textbooks were chosen because the school, by that time, emerged as a pivotal institution in the reproduction of class relations. The quest for mobility revolves around the school. Protestors sought class respect, community autonomy, and control over a crucial allocating mechanism of social class. ${ }^{13}$ While not dealing with the textbook controversy specifically, John Gaventa's Power and Powerlessness: Quiescence and Rebellion in an Appalachian Valley stresses several important themes found in the parents' rebellion in Kanawha County. Gaventa argues that power works to develop and maintain the quiescence of the powerless. Rebellion can only occur as power relationships shift. By working together, power and powerlessness keep issues from arising, grievances from being voiced, and interests from being recognized. This sense of powerlessness develops out of a long process. Continual defeat gives rise not only to the deferral of action, but also to a sense of powerlessness, which, in turn, affects the consciousness of potential challengers about grievances, strategies, or possibilities for change. This debilitating consciousness kicks off the cyclical decline in political participation and acceptance of powerlessness. ${ }^{14}$

"Power serves to create power," Gaventa asserts: "Powerlessness serves to re-enforce powerlessness. Power relationships, once established, are self-sustaining."15 Applying Gaventa’s model to Kanawha County, the families in rebellion deferred for the longest time to the power elite situated around the white-collar technocrats of Charleston. While the miners of the Upper 
Kanawha Valley had a history of union unrest as Billings and Clelland stress, the miners and other working-class families acquiesced in matters of the state to this power elite, enabling the miners and others in the working class of the Kanawha Valley to slip into powerlessness. Gaventa punctuates that for a change to occur, the powerless must develop their own resources for challenge - organization, information, sustaining values - to counter the prevailing mobilization of bias. ${ }^{16}$ The beginnings of that mobilization sprouted during the textbook controversy as a previously passive segment of the population challenged that power relationship.

These three views have their strengths and weaknesses. Page and Clelland's notion that the protestors acted out of a way to regain control over a way of life snatched out of their hands corresponds well with Billings and Goldman's thesis of the families rebelling in defense of working-class culture. Their only difference seems to be one of semantics. Page and Clelland too readily discount poverty as a variable. While most protestors floated above the poverty line, they could best be described as "working poor." ${ }^{17}$ A missed paycheck here or there could spell disaster. The explanation Billings and Goldman give for the protestors choosing textbooks to get angry about is fresh, but they underestimate the role of religion. Either Evangelical or Fundamentalist, the protestors' moral outrage was deeply rooted in their faith, and it was more than just a common frame of reference or tool. The two fail to recognize or respect the growing power of conservative Christian elements in the country at the time of the controversy and at the time of their publication. Both Page and Clelland and Billings and Goldman's conclusions work well in Gaventa's dimensions of power and powerlessness as explanations for the mobilization of the powerless against the established barriers of the powerful. The protestors can be seen as 
being powerless prior to their demonstrations, but by the end they managed to mobilize and compete, as just another interest group, against the powerful in a pluralistic society. Ironic, since their battle appeared to be against that same pluralist society. The controversy did not burst out against modernity and pluralism, but as a means to control that pluralism in a changing world.

James Moffett offers a unique perspective on the textbook controversy with his Storm in the Mountains: A Case Study of Censorship, Conflict, and Consciousness. A leading educator in the country during his time, Moffett presided as director of the Interaction textbook series, published in 1973, which provided the protestors in Kanawha County a lot of fodder for their objections. From this vantage point, Moffett delves into the textbook controversy fourteen years hence.

Moffett touches all of the important bases concerning the controversy itself. He briefly details the chronology of events and establishes the main characters, and he does this without stalling the book in a simple rehashing of the controversy. The preface and the prologue both show Moffett's willingness to give in to stereotypes; from the beginning Moffett seems to place himself on a pedestal, looking down at the protestors. He claims to differ from most liberals, by not patronizing the "poor, ill-educated, or disenfranchised people" and by treating the religious values of the protestors seriously. By the end of Storm in the Mountains, Moffett fails to keep his promise, for he spends the third part of the book tearing down the protestors' religious beliefs as a cause for their actions.

The most intriguing aspect of the book is Moffett's examination into why the protestors acted the way that they did. Moffett coins the term "agnosis" to describe the protestors' "not wanting to know" mentality, which also inhabits the "authoritarian," "dogmatic,” and 
"prefascist" personalities. The protestors, also those associated with the New Right that claim them, try to overcome negativism by denying it and by fantasizing its opposite. Moffett places great emphasis on the psychological development of those opposed to his textbooks. The psychological aspect mentioned by Moffett does help bring the textbook controversy down to a more personal level, but to simply label all the protestors authoritarian personalities accomplishes little. The protestors were individuals and each had individual reasons for acting, which shouldn't be forgotten.

Moffett does provide four valuable interviews with participants of the textbook controversy. Three were conducted with a several of the protest leaders: Ezra Graley (lay preacher), Elmer Fike (businessman), and Avis Hill (lay preacher). These provide useful insight into the minds of the protestors, and collects their thoughts on important issues such as race, communism, and religion. The fourth interview was with a employee of the Kanawha County School Board, who wished to remain anonymous, which tells you a little about the animosity that remains in the Kanawha Valley stemming from the textbook controversy. The employee gives a good impression of the other side of the controversy, with thoughts on intentions of the protestors and their behavior. She is one of the few who were against or just stuck in the middle who has been able to tell her story.

Within the past decade, a few more have revisited the textbook controversy. The PBS documentary With God on Our Side and the companion book written by William Martin both portray the controversy within the framework of the rise in conservative Christianity in America over the last half century. Interviewing some of the key participants like Alice Moore, Rev. James Lewis, and James McKenna, the two works suggest that something larger was at work: 
"That same feeling that government could no longer be trusted to fix things may have pressed Evangelical Christians in West Virginia to take up arms in the cultural wars." ${ }^{18}$ For the first time, topics such as secular humanism and the New Right were being discussed in connection with the textbook controversy.

Taking these claims even further, Carol Mason has written two articles dealing with the textbook controversy’s larger political implications. In “Textual Reproduction of Ethnicity in the Kanawha Valley: The 1974 Textbook Controversy Revisited,” Mason argued the controversy reproduced white Appalachian ethnicity in the post-civil rights era. She writes, "I see that the very definition of 'the (Appalachian) people’ was being re-made, despite intentions and motivations. It was being reproduced textually and politically according to shifting norms of race relations, gender roles, sexual mores, and class stratification."19 Mason places Alice Moore and the textbook controversy within the rise of the New Right, but she does not go into the formation or evolution of the New Right or the importance the textbook controversy had in relation to the growth of the New Right. Racial politics receive a fair bit of attention from Manson, and she properly concludes some sort of racial identity was involved in the textbook controversy. Along with this, she examines the white supremacists involved in the battle, suggesting the participation of the KKK, the John Birch Society, and the National Alliance prefigured some alliances that led to a resurgence of white supremacism in the 1980s and 1990s.

In the Spring of 2005, Mason published an article in Appalachian Journal. "An American Conflict: Representing the 1974 Kanawha County Textbook Controversy” reviews the three leading explanations for the textbook controversy: class warfare, anti-modern fundamentalism, and racism. She dismisses Billings and Goldman's major claim that while class allegiances were 
strong and articulated willingly throughout the textbook controversy other factors complicated the conflict and it can not be seen merely as a class war. Mason also doesn't buy into the notion that the textbook controversy was an inflammation of anti-modern fundamentalism: "The textbook controversy...was not an anti-modern throwback to the 1920s, a never-evolved fundamentalism of 'yesterday's people' living in the deep recesses of mountain folkways cut off from the rest of American society." ${ }^{20}$ Though Mason is correct in her analysis, she does not take into account the protestors' deep, religious convictions, which did play a significant role on the protestors' words and actions. Finally, Mason delves into the argument the controversy started over race-based resentment - an argument she alone seemingly constructed. So she ends up arguing against herself, and concludes there was more to it than simple hatred of blacks. She does not provide an explanation of her own, just a historiography of the literature, but the rest of this thesis will follow along similar lines of Mason's work in trying to tie the textbook controversy to a larger phenomenon in American politics. 


\section{Chapter Three}

\section{The Roots Are Going to Holler: Grassroots Activism}

Morning on the $17^{\text {th }}$ of September, 1974, in Charleston. It was Tuesday. They showed up early to make sure they got the best spot - right up close. Right in spittle range of the preachers. By ten, nigh on a thousand gathered on the river side steps of the Capitol. Most mingled. They knew each other and were friendly. They spent most of the summer out and about protesting guerrilla style, this helped builds bonds. Just past ten, up stepped Reverend Ezra Graley to the bullhorn and a hush followed. A big bear of a man with an appropriate set of accompanying pipes, Graley made his bones in the roofing business, but that day's rally roofing sat shotgun while his higher calling as minister drove.

At first, he demanded an audience with the Governor, Arch Alfred Moore, Jr., when that request was denied, he asked the crowd to march down to the school board offices. So they did. The drivers on Duffy Street weren't quite sure what approached, but it appeared to be hundreds of protestors flowing past their cars. This mass of angry parents waving placards and American flags made their way down Duffy then onto Washington St. where they began clustering around the entrance of the school board. For the better part of the last two weeks of September, the lawns of the school board building doubled as the protestors' fairgrounds. They kept a constant vigil over the facility, making sure no more seedy developments go on without their consent.

The marches, the pickets, the rallies, the meetings. All were initiated and driven by the protestors. Mostly working class folks built the textbook protest and kept it burning throughout 
the summer and fall of 1974 . The parents were responding to what they believed to be a gross injustice. The parents lashed out at the assault on their children, doing so by marching, picketing, and meeting. Unplanned by them, they created a grassroots movement that sparked the imagination of citizens all across the country, good or bad. But in terms of the actual actions taken by the protestors, nothing really differentiates them from other grassroots movements. Groups of one sort or another have marched in protest from the Depression-era Bonus Army to the civil rights marches in the South. People have picketed in the past, especially many of the protestors who hail from the eastern coalfields of the county and knew a thing or two about unions. Rallies have always been held. In the textbook controversy case, many of the "rallies" felt more like revivals. So none of the tactics were new ideas to the protestors. They spent most of the previous decade watching or reading about civil rights activists and anti-war protestors using the very same strategy. In fact, the protestors owed a debt to those previous protestors. While not ideologically aligned with many of them, the Kanawha County protestors did build on the methods employed by earlier protestors.

What makes the Kanawha County protestors unique? The protestors would hardly be considered liberal like the civil rights and anti-war protestors. Very few conservative grassroots movements formed around a single-issue in the years leading up to the textbook controversy. Kanawha County proved to be a textbook itself for other single-issue, conservative grassroots movements that followed throughout the seventies. The controversy's timing also made it unique, for it came during a resurgence of citizen activism throughout the nation and in Appalachia. In terms of Appalachian activism, the textbook controversy goes largely unnoticed due to its conservative nature, while environmental and miners' causes receive the bulk of 
attention from scholars, but this also seems to tie into the rural-centric atmosphere of Appalachian history. So the timing as well as the manner in which the protest unfolded make this textbook controversy such an interesting study of 1970s grassroots activism.

No precise date exists for when the protest began. It just did. No good date exists for when the protest ended. It just sort of fluttered away as people lost interest or the heart to continue, although there were still flare-ups throughout 1975. All of this makes tracing the rise and fall of this grassroots uprising difficult.

Pigeon holing this event as some sort of crusade is not my goal, but the point needs to be made that the church played the major role in organizing the people. The tactics used to protest the textbooks were not found in the Bible; they were rather found in the blood of the past, the traditions, as Dwight Billings and Robert Goldman suggest. Billings and Goldman suggest this struggle over books was not undertaken by a lone group of rural, backwater traditionalists but a fight of the working class, who had a heightened sense of occupational consciousness. ${ }^{1}$ Some truth exists. Rev. Marvin Horan stated on the relationship between Elmer Fike and other business leaders of the area:

[Fike's] followers are our followers..., we work together, our movement is not divided.... He is a businessman, so his activity is on a higher level than ours....Well..., they are businessmen. They own the factory, and we work for him.... We also have lawyers in this, that takes care of our business that we don't have the education to do.... However, they respect our position and we respect theirs, and we work hand in hand. ${ }^{2}$

Shades of inferiority fall over Horan as he discussed the business and professional interest in the textbook movement, hinting at the occupational consciousness underlying Billings and Goldman's argument. Protestors had no illusion about what they were: hard working with a blue- 
collar and part of the Pabst-swilling proletariat. In that heritage, they developed a tradition of activism not shared by the urbanites in Charleston and the surrounding suburbs. They earned their degrees on the picket line and were well versed in the art of the strike. It comes as no surprise that protestors would fall back on their time-tested and tried methods.

While the strike and picket provided a useful foundation, protestors built upon this by learning from social movements of the sixties, the same movements that directly produced many of the objectionable material in the textbooks. "Here in the seventies, parents have learned from the tumultuous sixties that if you don't like the way things are going you have every right and a considerable duty to stand up and say so. Someone may notice. Better yet, someone may do something about it.”3 The protestors used similar tactics like marches, sit-ins, and mass meetings used by the civil rights protestors as well as the anti-Vietnam War protestors. But maybe more important was the sense of entitlement these movements gave many a person all over the country. As witnessed in the Daily-Mail editorial, citizens gained a sense of duty to speak their mind if they felt they have been wronged. For the protestors the church provided a means for them to speak up and preachers provided many with a voice.

A movement such as the textbook controversy normally forms in traditional institutions, such as the church, because these intentions retain some sort of political and organizational insulation from the control of elites like witnessed in the civil rights movement. One of the most exhilarating and empowering aspects of insurgency movements is rediscovering the insurgent elements of traditions and institutions. This rediscovery presents struggles in ancient folkways and remembrances and often results in traditions and revitalization and not demise. ${ }^{4}$ Protestors seemed energized throughout much of the fall of ` 74 , which corresponds to their rediscovery of 
traditions always there but laid dormant. It took the textbooks to arouse these traditions, this vision, that rejuvenated them for the fight.

A movement incubates an alternate vision that seeks to preserve a people's way of life while it also changes society. This idea compliments the objections of the protestors. The church, in turn, acted as a place where their grievances could be aired amongst one another. A place of support. That community - the church - already existed and was well established in their neighborhoods, and this allowed a protest structure to be built upon that foundation. It is not so unlike the "free spaces" Harry C. Boyte and Sara Evans speak of. They define free spaces as "settings between private lives and large-scale institutions where ordinary citizens can act with dignity, independence, and vision. There are, in the main, voluntary forms of association with a relatively open and participatory character." ${ }^{, 5}$ The churches opened their doors and local pastors dished out healthy portions of their opinions from both sides. Jim Lewis, rector of Charleston's Episcopal Church, was the most vocal pro-text proponent in the controversy, who upheld the quality of the textbooks and could be heard on several radio stations calling for mediation. An article of his found itself reprinted in many newspapers all around the country, and he appeared on numerous area churches made sure their views were heard. ${ }^{6}$

The two Charleston dailies, Charleston Gazette and Charleston Daily-Mail, were littered with paid advertisements from small, mostly fundamental churches, whose pastors led the opposition to the textbooks. In an open letter to Superintendent Underwood, the Mount Calvary Missionary Baptist proposed "to fulfill all obligations of loyal citizens, but are constrained to declare against participating in violent insurrection, property damage, aiding or abetting in or the actual destruction of human life, but we intend to protest and taking our stand in Christian 
ethics." In another letter, this one from the members of the congregation of Rock Branch Church of God Mission, they proclaimed, "Ours is a voice of opposition: not to education, but to any teaching written or oral, in our public schools that portrays profanity as a form of 'selfexpression’ and directly or suggestively teaches against the authority of God, Government, and the home." ${ }^{8}$ The Church of Jesus Christ of Charleston and its pastor Lewis Harrah made a proclamation which read:

BE IT FURTHER RESOLVED, that parents instruct their children not to read, study or have these books in their possession, or to attend classes or schools where said books are used as curriculum....

BE IT FURTHER RESOLVED, that the Church of Jesus Christ, North Charleston, W. Va. Do everything in its power within the law, to see these textbooks removed from the Kanawha County Schools, knowing that we cannot attend school as long as the books are there, if it means forever.

BE IT FURTHER RESOLVED, that we advise our people to stand for their religious convictions, regardless of the sacrifice or the price we might have to pay. ${ }^{9}$

These examples portray the independent church's willingness to voice their opinion and take an active role in the protest movement itself. not surprisingly, the church played such a vital role in the controversy given the tradition of religion in Appalachia.

A mass movement needs a spark, something to unite people - have something for the people to rally behind. The textbook controversy never really had such an event. The textbooks themselves provided a spark, but not until that stormy night of the Board meeting in June did the people realize they needed to unite and do something to cast these books into the pits of hell.

On the surface the meeting was important, because for the simple fact the decision to buy the textbooks passed the vote by the board. The decision to purchase pump-primed the entire 
controversy. Prior to the June meeting, the whole ordeal merely involved words, mostly spoken by Alice Moore in her quest to drum up support against the textbooks. After the meeting, action supplanted words for the protestors. It's when dissidents were transformed into protestors.

Those in attendance also foreshadowed how the rest of the textbook controversy would play out in the long autumn months ahead. It was loud and raucous. From the tapes of the meeting, it sounds more like a bowling alley on league night than a school board meeting. Gavel shots rang out at regular intervals and speakers were constantly being interrupted. The chanting and overall raucous behavior of the anti-text crowd set the standard for future behavior at various protest functions throughout the county. They drowned out all opposition, and they do deserve credit for overpowering the pro-text faction.

Something like a thousand people showed up for that meeting most of whom were against the books. They came thinking that they were going to be heard, or I should say they came believing the Board would recognize them. Now the board did hear from a few anti-text speakers, but most of the sixteen speakers praised the books. ${ }^{10}$ A lot of resentment came out of this meeting from the way the Board failed to allow anti-text speakers to have the floor. Imagine how this would play out for an anti-texter in attendance. There you are with a couple hundred of like-minded citizens and all the board hears from are the pro-texters of which only a couple fistfuls dot the board auditorium. The situation ripened for paranoia to turn into conspiracy. And resentment turned to spite as board member after board member voted to buy the textbooks.

Those against the textbooks felt the board members already had their minds made up, and did not care to hear from the protestors. Out of this meeting came the venom which filled many of the protestors toward the members of the school board. ${ }^{11}$ 
It is important to note that those in attendance identified themselves with their churches, showing where the protestor's true alliances lay. Numerous letters to the editors flooded into the newspapers with statements to their Christianity: “I am proud to say that I’m a West Virginian but most of all I'm proud to be a Christian!" ${ }^{22}$ They identified themselves more as Christians than as working-class heroes, and this helps to explain in large part the influence the church had on the protests. If their primary identifying mark was as a Christian, then of course they would flock to the church for help and guidance like they would in any type of crisis. It was what they knew. It was a place of comfort.

Also, their identifying themselves as Christians provides insight into their rallying around Alice Moore, who at the meeting was the only one sticking up for the anti-texters. She mostly accosted the pro-text speakers on the issue of the religious tones in the book, specifically the claim that the books tore down the child's religious upbringing. The way she held her own and took to task the pro-text speakers for those god awful textbooks made her a saint to the antitexters, and solidified her place in their hearts. "I am strong against the books and I know Mrs. Moore is right. I met her once. I wish she would run for president.... I certainly would cast my vote for her," wrote one Nitro resident. ${ }^{13}$

After the June $27^{\text {th }}$ meeting, mobilization began for the new protestors. In the dying days of that hot summer, parents formed a variety of different organizations like the ChristianAmerican Parents and Concerned Citizens. Both called on members for political grassroots activism. Christian-American Parents called for the boycott and picketing of all area Heck's, of which board member Russell L. Isaacs served as president. While the action itself didn't have any material effect on Isaacs' opinion or Heck's business, the decision to boycott and picket 
Heck's proved significant. It showed incredible savvy on the part of the Christian-American Parents to go after business, to go after the money in the valley - a tactic they would use again and again with varying degrees of success through the county. And maybe they could disrupt business enough to make Isaacs change his mind, or better yet make him resign. Plus, the move generated great press for the protestors. It got their cause out there in the open, their picture in the paper - the three or four sign carriers with their children at their feet raising some hell out in front of Heck’s. Great press. Great way to expand their message.

Newspapers quoted the protestors. The evening news broadcast their image and words across the valley. Every single bit of it helped the protestors' message disseminate throughout the entire valley and throughout the entire country. It showed to those who were silent or who were secretly against the books that they were not alone. It showed the silent majority that they were in the majority: "The silent majority are the hundreds of parents in Kanawha County who kept their children in school and did not boycott. We are the ones who stood in the background and hoped the 'mess' would be cleaned up by the people who showed their convictions and stood up for them." ${ }^{, 14}$ Actions like the Heck's pickets and the protest on the Governor's mansion enlarged the protestors' sense of duty and their support base. It increased their exposure, It increased the exposure of their message to the general public. As the school year approached, the anti-text movement quickly found itself with a large and loyal following exemplified by the Concerned Citizens rallies at St. Albans and Campbells Creek on August 27 which drew hundreds of protestors. At the rallies, those in attendance voted unanimously to boycott the start of the new school year - beginning September 3.

Come September $3^{\text {rd }}$, the protestors were ready. They established pickets outside of 
several area schools disrupting some schools, mainly in the eastern sections of the county. Also, on that first day of school, the protestors devised a plan of guerrilla action to disrupt the Kanawha Valley. Roving bands of picketers filed into vans and drove off down the highway on their way to local businesses, whether it be a construction site or a trucking firm or the city bus department. These loyal troopers flocked to their designated locations to start some shit, accomplishing a major blow the following day, September $4^{\text {th }}$, when a contingent of protestors set up outside of Kanawha mines. Protestors knew full well that the miners were no more likely to cross a picket line than they were to break out into a stunning rendition of "No, No Nanette."

The region and Appalachia as a whole has a long history of resistance. Billings and Goldman stress the importance of having a grasp of the history of these working class communities. Without "understanding the tradition of working-class resistance in this portion of Kanawha County, one cannot comprehend the intensity of feelings with which a coal miner would say to a reporter: 'We built these schools with our sweat and taxes and son, no bureaucrat is going to tell me that my child has to learn garbage." ${ }^{\prime 15} \mathrm{~A}$ whole host of things gave the inhabitants of these working-class communities an elevated sense of their occupational consciousness like industrialization, over-expansion of the coal industry, cut-throat competition among operators, and continued opposition to unions. The whole weight of these events produced these communities and instilled in them a tradition of activism not shared by chemical workers or the middle-class residents of Charleston and surrounding communities.

This tradition of activism was primarily based around strikes in labor disputes but in the years leading up to the textbook controversy Appalachia experienced a rash of grassroots activity. In discussions of these grassroots movements in Appalachia, the textbook controversy 
gets little mention due to its conservative nature. Miners set out protesting for more democracy in the United Mine Workers of America and for recompense for their black lungs and to protect the land from harmful strip mining practices.

The archetypical Appalachian, according to the stereotype, is that of a passive victim, as quiescent, as accepting his lot in life and just whistling and whittling away in contentment. Over the past couple of decades, new scholarship shows that Appalachia never lacked a politics of resistance, especially with the regions rich and well-documented union activity. In terms of the textbook controversy the national media fell upon these stereotypes describing protestors as "those women in hair rollers and men in bib overalls, who go to school board meetings to denounce atheism and immorality in the classrooms of Kanawha County. They have old wringer washers on the front porches and drive battered pickup trucks. They have never heard of John Dewey or Jean Piaget. ${ }^{16}$ If the qualification for being backwards is not following the teaching philosophy of Jean Piaget, then Appalachia would not feel so alone. Reliance on the hillbilly stereotype hurts Appalachia's image and damages the meaning behind the larger implications of the textbook controversy. Was this just an outpouring of hillbilly culture against a 'new morality’? Or does more lurk in the backyard - something larger?

Something larger is always at work in a movement; something has to be driving it. A movement develops in a historical context that includes but also transcends local community borders. ${ }^{17}$ Transcendence occurred in the textbook controversy as a flurry of grassroots movements arose in Appalachia. Most notably in these Appalachian grassroots movements were the Black Lung Association and the anti-strip mining campaigns. While the textbook controversy does not fit into this trend, because the underlying controversy has nothing to do with coal, it 
does follow in the footsteps of resistance. What all these movements represent is not only a tearing down of those old stereotypes of Appalachians but they demonstrate the complexity of human nature. The people at the center of all of these movements were not terribly different. But while the BLA and anti-strip mining protests were progressive in their outlook, the textbook controversy was conservative in every sense of the word, making labeling the participants difficult.

The BLA and strip-mining are two distinct movements that probably only could have arisen in Appalachia, though strip-mining is present at many different locations around the country its affects on Appalachia appear more severe than elsewhere. But these two campaigns took years to develop and are linked directly to the mechanization of the coal mining industry.

Cases of black lung, pneumonconisosis - where the person breathes in the coal dust and it settles in the miner's lungs leading to a whole host of ailments - began to grow throughout the sixties. As continuous mining machines drilled away more and more coal dust was kicked into the air for the miners to breathe in. Black lung remained a closet disease for much of the 1960s. After working on continuous mining for a decade or more, miners began noticing they found it hard to catch their breath. They were suffering their collective illnesses individually. Slowly the rank-and-file miner's health consciousness built up over a number of union conventions, while at work, at the Fund's clinics, and in the occasional medical study. As consciousness grew so did the anger over the inaction of the union to rectify the miner's failing lungs. Anger transformed into outrage in late November 1968, when a mine explosion at Farmington, West Virginia, killed 78 miners. Outrage came from the union's response. UMW president Tony Boyle on the scene at Farmington three days after the disaster said, "As long as we mine coal, there is always this 
inherent danger."18 Boyle then went on to praise Consolidated Coal for being one of the best companies to work with in terms of cooperation and safety. ${ }^{19}$

Shortly after the Farmington tragedy, many retired and disabled miners joined together to form the Black Lung Association. They successfully challenged the West Virginia State Legislature in changing the state’s workers' compensation laws. Later, their efforts led to federal legislation in 1969 with the passage of the Coal Mine Health and Safety Act. Throughout the BLA remained a local community organizing effort with county chapters providing the miners with the most useful service. At the community level, the diversity of the movement appears. It included women, African-Americans, the young and the old. The county chapters spent their efforts offering assistance for individuals applying for federal black lung compensation claims. They pressured the Social Security Administration and the Congress to reform the compensation programs. $^{20}$

The BLA owes a debt to the War on Poverty, as noted by Curtis Seltzer. The war seeded West Virginia with a network of college-educated activists not beholden to local power. They were hewn out of student protests, with the local meeting, demonstration, direct demand for immediate political gratification, helping the bottom confront the top serving as their models of political participation. Any old model such of political appeal would be undermined by the old guard, who had devised plans of attack. By implementing a new model, one that blended their traditional use of strikes with the new skills of the community organizer, they were able to force the legislators to accommodate them. ${ }^{21}$

The mixing of this new blood and ideas and ways with the miners' tradition produced results and a style the establishment was not ready for. The coal operators and state legislators 
learned to deal with traditional ways to handle miner protests, which usually took the form of strikes, but these new community action programs messed up the old order. A new set of problems called for new solutions.

In the fight against strip-mining this new political paradigm began to form. The place was called Clear Creek in Knott County, Kentucky. There a group of women got together in 1967 and created an organization called Appalachian Group to Save the Land and People. The sole purpose was to fight strip-mining in the county. But why strip-mining? Original member Mary Beth Bingman recalls, "Resistance to strip mining came from people’s connection to and love for the land, for the mountains, for their communities.” ${ }^{22}$ To protect their land, their communities, these activists, most of whom were women, blocked mining operations by trudging miles through mud and muck up mountains to stand off with large bulldozers. Sometimes armed, sometimes not, either way they sat there in front of the big machines. This direct action had to come from some place and Bingman places it at the feet of the other social movements raging around the country at the time. ${ }^{23}$

While the BLA and strip mining movements have a lot of differences, quite a lot of similarities exist. Obviously there is geography and people. It was Appalachian and these were Appalachians, working-class men and women. They learned tactics from community-based, direct-action movements, like organizing demonstrations, rallies, picketing, lobbying. Also, they both revolved around a single issue and reacted to actions already performed, limiting the impact of their effectiveness. The BLA never broadened its focus to include prevention, as Seltzer states, "by focusing exclusively on compensation, BLA confines its base to disabled and retired miners - a base that time and legislative victories would shrink.” ${ }^{24}$ For strip mining opponents, 
the economic realities of the region meant these loosely organized groups could only resist and not win. The focus on a single issue would not lead to a fundamental changes in society. Without the foundation, without the dedication to the long slow process that real change requires, all movements in the end will fail, especially if the movement is built on a single issue like textbooks or strip mining.

Similar attitudes and action permeated throughout the Kanawha Valley in 1974, as protestors went out of the traditional modes of grievance address for political matters (letter writing, phone calls, ballot box). Only immediate removal of the texts would satisfy the dissidents, so drastic measures needed to be taken; hence, the marches, the pickets, the strikes, the mass meetings, the sit-ins, the telethon, all manners about which to gain support and dictate policy. The old methods, well, got old and tired and were no longer all that effective. For a change to occur new pressures need to be applied to the system. Without any kind of challenge or pressure from established sources then the status quo will prevail. The protestors in Kanawha County recognized fairly quickly, so they resorted to new forms of protest in a new context. This explains how their objections became so loud compared to the pro-text faction.

Everything was up for grabs now. The Black Lung Association made sure of that. The anti-strip mining protestors made sure of that. Civil rights activists made sure of that. War protestors, women's lib fighters, gay rights activists, all of them down to community activism created a new order in which the people and the government relate to each other. There also appeared a better understanding of how the world operated; a good example is the protestors' use of the picket. While many have criticized the protestors' use of guerrilla pickets at local businesses around the county, it shows an incredible amount of deftness. If they attacked the 
economy and caused a big enough stink, then the Board or government would be forced to listen. Forced to respond. Eventually this dooms a movement, when the government or whoever does take notice and initiates measures which will undermine the structure of the movement. Three choices present themselves to the government. First, they may ignore the protestors. Second, they may employ punitive measures against the protestors. Finally, the government may attempt to conciliate them. ${ }^{25}$ In Kanawha County, the local authorities tried all three, but the third option finally proved to be the final straw in quelling the unrest. This benefits the government, for, as Frances Fox Piven and Richard A. Cloward state, "at the same time that government makes efforts to reintegrate disaffected groups and to guide them into less politically disturbing forms of behavior, it also moves to isolate them from potential supporters and, by doing so, diminishes the morale of the movement. ${ }^{, 26}$ During this attempt to conciliate, the movement erodes under these influences. Leaders are attracted by new opportunities. Private Christian schools seemed to draw the attention of the anti-textbook leaders, and they placed their efforts in trying to establish these schools instead of trying to get the books out of the schools.

Throughout the fall, the protestors remained rather fluid in their actions and rhetoric as well as organization and structure. Nearly every day picketers stationed themselves outside various businesses. Moving in teams, they would hit a Krogers or Walker Machinery or Union Carbide or the KRT bus line or the county school bus lot. They seemingly appeared at random and without notice like a villain out of Batman only there was no Dark Knight to foil their plans. This fluidity allowed them to strike as they did and to maximize their impact. Lying underneath this was the dedication to the cause shown by many of the protestors. They would battle to the end. This partly comes from how the protestors viewed the controversy as a battle between the 
forces of good and evil. Protestors demonized the textbooks and those in them and they successfully marginalized proponents of the texts. By placing pro-texters and the texts themselves outside the realm of mainstream values, the protestors controlled the initiative of dialogue, because "it is easier to rationalize stereotyping, prejudice, discrimination, scapegoating, and even violence against those who are dehumanized or demonized."27 The protestors constantly attacked the texts, the writers inside of them, the pro-text faction, and the government officials standing in their way. The press reacted to them. The public reacted to them. They were in control of the controversy, but they were not even in control of themselves. The same fluidity that allowed them so much success also played a large part in their failure to remove the texts. The organization and structure of the movement flowed uninhibited as well, which led to serious problems throughout the controversy.

So who was in charge? This was problem - no one person or group was. The protestors sort of went, did, and said what they wanted to. A handful of local preachers acted as spokespersons for the protestors, and while they might have had some say over the actions of their individual congregations, their words were perceived as utterly worthless by many of the protestors when push came to shove. So when violence and fire bombings plagued the Kanawha County elementary schools the leaders were as helpless as everybody else. It also did not help that one of the more vocal spokespersons, the Rev. Marvin Horan, was convicted of conspiring to dynamite an area elementary school. Also, without a clear leadership chain of command, the school board and other government officials did not have a good grasp on who to talk to in order to try and broker a peace. On numerous occasions, the protestors' spokespersons contradicted each other. A week after school started, the Board agreed to remove the texts from the classroom 
for the time being and Horan accepted and proclaimed, "It’s Over!” Only to have another Reverend, Ezra Graley, come along and reject the offer, because it did not remove the textbooks from the classrooms for good. Many also called into question the motives behind these preachers. Boardmember Russel Isaacs recalls that these preachers "got all this publicity and face time and were having a good ol’ time.,28

With a lack of coherent leadership, a void formed in the message department. No other unifying message other than getting the textbooks out of the schools existed. Due to the protestors' vilification of the textbooks, they simply refused any sort of compromise. The board on several occasions made concessions to the protestors, but each time the protestors brushed off these attempts at mediation. They enlisted the help of James McKenna, a lawyer from the conservative think tank Heritage Foundation, to help them draft a list of demands. This was the only time that the protestors actually had a set of goals to work toward and for the school board to work with.

The school board made numerous concessions throughout the controversy, such as temporarily taking the disputed texts out of the schoolrooms and establishing a review board to once again paw through the books and file a report on the books' educational quality. Never good enough, the protestors kept demanding the absolute removal of the texts and the resignations of the board members who voted for the texts. As they grew more frustrated with the situation, their attention drifted away from the textbooks toward the formation of private Christian schools. When the Board agreed to completely remove the disputed texts from the classrooms, only to be viewed by students with written parental permission, and the Board changed the textbook adoption process, it went without celebration amongst the protestors, 
which turned out to be one of the sad outcomes of the textbook controversy. It brought a change that ultimately no one care or benefited from.

The controversy's most militant phase came to a halt when Governor Arch A. Moore, Jr., called in the state police, thus halting the violence in the area. Firebombings ceased. The pot shots at the school buses stopped. Protestors seemed to respect the authority of the state police and the governor. So why didn't Moore call in the state police earlier? Throughout the controversy, Moore remained aloof from what was happening surrounding him. He believed the matter to be a local one, saying, "It is difficult for state government to move in a situation where state government itself has no control over the parties or the subject matter involved."29 Over thirty years later, Moore still remains aloof from what happened. He claims to have been "geographically out of the controversy," and he only acted when he "felt something positive could be done. ${ }^{30}$ Many, including the newspapers, thought Moore was playing politics, straddling the issue, so as not to isolate the various blocks of voters.

A new populism arose during the 1970s. People gained a sense of entitlement during this era - an entitlement to living the lives they want to live free of having their freedoms trounced upon. For liberals this achievement came through the civil rights movement, women's liberation movement, and the gay rights movement. But at the same time a conservative element bubbled underneath America's surface and it exploded forth from the local level with an event like the textbook controversy or anti-busing campaign in Boston. Now the textbook controversy was not the first instance of this emerging conservative element in America. Numerous instances throughout the sixties, whether it be Goldwater's 1964 presidential campaign or the many George Wallace campaigns; all of these showed tremendous grassroots potential. Being one of 
the first instances of a single-issue conservative movement, the textbook controversy popped up and led the way for other such causes will have a significant impact on the future of the conservative movement as groups such as the New Right and the New Religious Right sought to gain political power. The grassroots movements gave these associations an avenue to power. It showed them a consistency existed. It showed a need existed for a change to replace the gains made from just the previous decade. 


\section{Chapter Four}

\section{America Without Tears: Backlash Politics}

Backlash politics have always been a part of the American political landscape. The pluralistic nature of American society constitutes an internal struggle by particular interest groups for a voice. As one voice makes itself heard three more have to wait for their turn. Pluralism may imply acceptance of many different groups and people but nowhere does it say you have to like those groups. This comes out of the natural ebb and flow of politics. Proportionally, while one group is up another is on its way down. Whether or not the group on the ascendancy gained its success at the expense of the down and out group, those on the decline feel resentment and isolation. One of the best examples of this relationship occurred during the sixties and seventies. One group, African-Americans, started the decade out in isolation away from the halls of Washington. They made their voice heard dy demonstrations, boycotts, marches, and. They won some hard fought concessions from the federal, state, and local governments - like integration (both public and private sectors), voting rights, affirmative action, etc. Another group, Southern whites and blue collar workers were not so keen on these changes. And they made it be known. Their outcry came nearly as soon as African-American began making gains, like the protests surrounding the integration of colleges.

The sixties incarnation of the backlash manifested itself in Alabama Governor George Wallace, who manufactured himself into a spokesman for these worried whites, fearing the encroachment of blacks and lambasting the liberals for allowing it. But just what was Wallace 
and constituency backlashing against? If the sixties birthed a new kind of liberalism, then the decade also produced a new kind of conservatism. At the crossroads of Goldwater's doomed campaign and the populist rhetoric of George Wallace, arose this new conservatism that blossomed throughout the seventies showing itself at the textbook controversy. By the midseventies, the division between old and new came quite clear, and this new conservatism quickly left the old guard behind. In fact, the general direction of American politics shifted decisively to the right on a wide range of issues by the mid-1970s, with the textbook controversy in the midst of this shift. ${ }^{1}$

Nineteen seventy-four, America, from just the decade prior, undergoes many turbulent changes. The country was losing in the world economy and market. Vietnam lay completely abandoned. OPEC raised oil prices nearly four hundred percent. Unemployment rose seventyfive percent. Watergate and Nixon's resignation left the entire country in a whiskey stupor. Social upheaval came ten a penny during the sixties from the civil rights movement, the anti-war movement, women's liberation movement, the rise in crime, the proliferation of the drug culture to the War on Poverty. As these images flickered across television sets all over America, some people took notice. They noticed changes that seemed to undermine their beliefs or traditions. These changes came without their consent and were dictated by the government. To that population not desiring these changes, government institutions appeared to be dictating to them. In Appalachia, as elsewhere, the thrust of this change affected one of the most personal symbols of the government - the schools - the purveying program of that change being the War on Poverty.

The idea that mountaineers lived in a "culture of poverty" prevailed as the dominant 
attitude of the War on Poverty in Appalachia. The theory being a culture of poverty develops out of a group's hopelessness and its acknowledgment that they can never obtain success in terms of the values and goals of their society. This hopelessness, much like powerlessness, perpetuates itself from generation to generation as the children absorb the basic values and attitudes of the subculture, rather than by the socially acceptable middle-class values. These poor people do not effectively participate or integrate themselves into the major institutions of the larger society. ${ }^{2}$

Strategists for the War on Poverty devised a plan to attack this culture at the point of selfgeneration - the children. Professional educators came in to teach the children, weakening the influence of the parents. Head Start programs were established, placing even younger children in the hands of these professionals, these strangers, these instruments of the government. Educators hoped to undermine the parental cycle responsible for the culture of poverty, and sought to break the dependency on the parents. Armed with modern and progressive materials, the teachers went to do their jobs. New textbooks reflected the ethnic and minority diversity of America. The National Education Association report on the Kanawha County conflict summed up the feelings:

The right of all students to learn that in the world and in this society, white is not always right; that white, middle-class values are not only, nor even always the best, values; and that the history of the United States is not one long, unblemished record of Christian benevolence and virtue. Teaching and learning these truths are not acts of subversion or irreligion. But to ignore is an act of blind patriotism and religious bigotry. ${ }^{3}$

Rev. Horan alluded to this shift in education, "the schools have been deteriorating over the past eight years, and the school system is still going down. We must come back to basic education.” The educational establishment in Appalachia also supported this shift in policy and curriculum for students. The general flavor of Appalachian educators seemed to be that Appalachian schools 
need to be built up, so they could compete with the rest of the country. They kept pounding and pounding that Appalachia needed to be integrated into some wider national culture. Focus was particularly placed upon the inadequacy of Appalachian schools to produce educated and qualified workers. Rex Smith, West Virginia State Superintendent of Schools during the 1960s, stated in an address on the long range plan of education in the state:

Some of the jobs which will need to filled ten years from now don't even exist today. This means that we [Appalachian educators] must plan a curriculum which offers a basic educational program with the opportunity to specialize in new fields as these fields develop. And, in order to do this, we must exert a concerted effort to tear down and eliminate Appalachia's traditional regional isolation. The United States population today is highly mobile. Many of our young people here in Appalachia when they get out of school go to work in other parts of the country. This makes it absolutely necessary for us to look to the rest of the nation when plan our curricula. We can't train our young people for just the jobs which exist in Appalachia. We have to train them for jobs which exist all over the country. ${ }^{5}$

The War on Poverty attempted to modernize Appalachians, bring them up to the rest of the nation. Of all the rural social institutions, education showed the most promise for linking Appalachia to a wider society. Education thus served as a cultural bridge between the two systems for the diffusion of the Great Society's norms into the mountains. ${ }^{6}$ Education transmits this cultural bridge from generation to generation and provides the best link to affecting change by breaking down this culture of poverty. "The school, by teaching the normative patterns of the Great Society, inculcates the youngster with the culture of the Great Society and, through the processes of assimilation and substitution, furnishes him with a cultural link with the Great Society, allowing him to become an agent of change in the rural community or to make an easier adjustment to urban life if he migrates,” Harry K. Schwarzweller and James S. Brown note. ${ }^{7}$ By challenging the traditionalism of the mountaineers, Appalachians would ultimately 
choose modernization, because of the path already cleared by school systems. What Schwarzweller and Brown failed to recognize is the resistance there would be against change. Traditions, beliefs, faith cannot be brushed off by a little bit of schooling. It travels much deeper than that. The Kanawha County protestors demonstrated this willingness to fight change. The textbooks posed a threat, however real or imagined, and that provoked a reaction by the protestors.

Tangible threats surrounded people in the mountains, threats like school consolidation, which spelled the death of the community school. To educators these small rural schools were a burden to taxpayers and to them. "If we can consolidate our school systems and make our high schools large enough,” Rex Smith added the reasoning behind consolidation, "we'll be able to afford the expensive equipment and highly specialized personnel that we need. Frankly, I just don't see how we can maintain a high school with a graduation class of less than one hundred and still hope to provide the quality of teachers and services we need.”8

Threats surfaced in other areas like the previously mentioned Head Start programs. Commenting on the success rates of these programs in Appalachia, James Branscome observed, "There are apparently successful Head Start programs in Appalachia, though their success is probably due to the fact that the preschoolers have not yet been told they are incapable of doing something worthwhile or making a significant contribution to society.”9 The goal was to keep Head Start as local as possible. Too much consolidation of elementary schools and busing lessened the opportunities for getting to know home situation and families. ${ }^{10}$

While Head Start and consolidation found their ways to Kanawha County, language arts textbooks did most of the upsetting. The selected books, while trying to please everybody in the 
complex and diverse county, alienated a large segment of that same county. Feelings of mistrust toward institutions already existed in the minds of many of the parents (and many Americans in general), and this new incursion justified those fears. Many called for a return to the old standard, the McGuffey Readers: "If we were not so far out in the dispensation of time and so near the night of darkness recorded in John 9:4, and could return back to the McGuffey’s series there could be some bright outlook for our young generation.”11

What was it about those McGuffey readers that attracted the protestors? A consistent murmur echoed around the Kanawha Valley for a return to these old books. Fliers announcing their sale were distributed by the American Opinion Bookstore, the local John Birch Society front group. And why wouldn't the protestors love these books? They included the writings from the classics and not from some radical African-Americans. The books included themes valuable to the protestors like nationalism, patriotism, constitutionalism, Christian virtues, and conservative values. To many, McGuffey's inspired hope in the mission of America, which according to some lessons found in the readers was ordained by God. ${ }^{12}$ The protestors themselves were not alone in history. More than thirty years prior to their backlash, Bruce Crawford, director of West Virginia Publicity Commission, expressed strikingly similar sentiments to the protestors, speaking to the Tri-State McGuffey Clubs Conference in the midst of the World War II:

Good men and good nations, living by simple and great truths, do not quickly restore to war; they fight only in self-defense - in defense of the moral and spiritual values by which they live. Evil men, who never were guided by such maxims as those of the McGuffey Readers, quickly turn to the use of pure force. They break faith. They take advantage of gentler peoples. Kindness, fairness, honor, truth and beauty are brushed aside by evil men in their brutal seizure and exercise of power. The universal practice of the fine preachments of the McGuffey Readers would enable humanity to live a life of goodness, peace, and 


\section{happiness. ${ }^{13}$}

Crawford's message sends a straight shot - the first axis of evil: Germany, Italy, and Japan came to evil due to moral deprivation, which McGuffey Readers could remedy. His advocation of fighting for morality and your own spiritual values would be taken up by the parents in Kanawha County, as they fought for the morality of their children.

People wanted something and not just in Appalachia. An isolated mass of the population festered under the surface, only waiting for a way out, a way to express themselves. It took a man like George Wallace to illustrate and communicate the feelings of so many frustrated whites, while paving the way for a new kind of politics. Wallace sculpted a language exploiting the fears and hatreds of whites without using the cruder vocabulary of traditional racism. Instead of the age-old southern cry of "Nigger, Nigger," he substituted a more subtle, segregationist language of the right to private property, community control, neighborhood schools, and union seniority. As the country shifted to a more open and diverse culture, Wallace crafted his language to meet this new America. ${ }^{14}$

Wallace's was a natural, but dangerous, rhetoric that appealed to millions by voicing powerful cultural beliefs and symbols. The sanctity of the traditional family, the centrality of overt religious beliefs, the importance of hard work, and the celebration of the autonomy of the local community, all of these attracted its followers. This new social conservatism reshaped American politics in the 1970s and 1980s and still holds a grip on present day politics. It provided a reference point for those wanting to turn America to a more hospitable place. It helped create the backlash to the sixties social upheaval. ${ }^{15}$

The rise of Wallace onto the national political scene remains one of the most intriguing 
aspects of the sixties. His movement came as a response to the black advancement in American society, leading what is commonly referred to as the "White Backlash.” Throughout the sixties and seventies, the white backlash became the most dominant form of backlash politics, which allowed Wallace to tap into a wide constituency of Southern whites, Northern blue-collar workers, and some in the middle class. Later the New Right will use this constituency for building their own majority.

The encroachment of blacks scared many whites, who had grown accustomed to and comfortable in Jim Crow's America. It was what they knew, and when it started to break down, they seemingly had no place to turn. Wallace provided leadership, a voice, a symbol for their struggle, for their fears: “As the civil rights movement expanded in the 1960s to inspire the women's rights movement, the antiwar movement, and the politics of sexual liberation, George Wallace adroitly broadened his message. Journalists might greet this growing counter culture with curiosity, even approval. But Wallace knew - instinctively, intuitively - that tens of millions of Americans despised the civil rights agitators, the antiwar demonstrations, the sexual exhibitionists as symbols of a fundamental decline in traditional cultural compass of God, family, and country.” For his efforts, Wallace forged a new kind of conservatism - social conservatism. A conservatism that stresses exactly those three things: God, family, and country. These three ideas would also form the backbone of all the protestors' complaints about the language arts textbooks. Wallace created a language for the protestors, though he was not the only politicians to call for a return to traditional American values. He was an alchemist using the racial fear, anti-communism, and cultural nostalgia. ${ }^{16}$ The protestors rode the coattails of George Wallace throughout the entire controversy. Wallace understood there were millions of 
Americans who felt nobody was paying attention to them that nobody cared about their frustrations.

Wallace did receive a fair percentage of the votes in the 1968 election. In Kanawha County, the Governor garnered 11,524 votes compared to Richard Nixon's 41,712 and Hubert Humphrey’s 46,650. (Put in extended footnote on Wallace’s cross party appeal with Rogin article and Durr book.) On July 19, 1975, active textbook spokesperson, Rev. Ezra Graley, then acting as Chairman of the Kanawha County American Party, hosted a dinner to organize political support for another Wallace presidential campaign in 1976. The ad read, “ATTENTION PATRIOTS! Textbook Protesters, Members of Kanawha County Tax-Payers Association and all Persons Who Love Our Children And Are Opposed to the Damning Filth Being Forced on them by Satanic Puppets...Are opposed to the Destruction of Our Property Rights and Constitutional Government through So-Called 'Planning \& Zoning', 'Land Use', and so-called 'Regional Government' Laws(?)"17 Betty Bates, who fought regional government and land use laws in Utah, delivered a speech railing against abortion, textbooks, and space flight. Forces of God and Satan struggled for control of the world, of the United States, and all of these destroyed freedom and the American way of life, Bates said.

While Wallace, the presidential candidate, received a little less than nine percent of the total Kanawha County vote, his ideas and language got good mileage from the protestors during the textbook controversy. In their objections to the books, parents made clear their ideals about what America should be and how it should be run. This was a political movement - people getting together to decide on how they will run their society, and they did not like what they saw in the textbooks. Three main sentiments common to conservative opposition appear in nearly all 
the complaints about the textbooks: anti-American, obscene, and anti-Christian. Three sentiments expressed by many all around the country about a number of different government intrusions on their daily life, but it took language arts textbooks for the people of Kanawha County to act.

The idea of school to most of the protestors clashed with that of the government's. Schooling involved the three "R's” and not much more. Children should not be taught to question their parents' authority or question God or question their surroundings. School should not expose children to sex, violence, and 'filthy' language. It is a place where the ideals of the country are to be taught and upheld, where the child is elevated and does not have the world knocked out from under them. The protestors sincerely loved their country, and they wanted that love to be transferred to their children. The school needed to reinforce that love. What the parents saw in those textbooks defied their logic and did not meet any of their qualifications about what school should be.

Many saw the books as being anti-American and communistic, for some excerpts held America in a different light than the protestors. This created a paradox for the protestors. While they loved their country and hated communists as much as any Bircher, they despised what their government is doing to their children. Books like Eldridge Cleaver’s Soul On Ice that openly challenges American institutions received much of the attention of the protestors. But they themselves openly revolted against the government - local, state, and federal. The government of the same country they loved. Protestors never really rectified this inconsistency. They made attempts, like Rev. Horan justifying the protestors’ actions:

Anytime a governmental system will provoke the citizens to anger, like the board of education has done, and... then send the law out on these (protesting) people to 
provoke them to anger..., now who would we say is ignorant, the people or the elected officials? We... never broke no law..., we did the only thing we could do in order to preserve the law, because if these books prevail, there won't be a need for any law.... Those people [the Board of Education] broke the law, and made me do what I'm doing now. They broke the law by... invasion of privacy, teaching my children things I absolutely forbid. ${ }^{18}$

But their reasoning comes off more as an excuse. Protestors spoke in generalities like fighting for freedom; fighting for the very same values the Founding Fathers fought for. "[The textbooks] undermine the very ideas and principles that America was founded on. Our country was founded by people who believed in God. Many of them gave their life so that we could have freedom.”19

Some even go as far as reinterpreting America's history a trait shared by Evangelicals all across the country: "It is incredible that anyone would accuse Thomas Jefferson of being an atheist when he so strongly professed being a Christian... Jefferson contributed to a Bible society and he did not see how anyone could fail to believe in God. ${ }^{20}$ Another protestor goes even further, while praising the Founding Fathers as "fundamental Bible Christians," he bashed the producers of the Constitution, "which is completely adverse to fundamental Bible Christianity," for allowing abortion, women to have equal rights, mixed marriages, unions, and democracy: “The Constitution allows government by democracy, the Bible doesn’t." ${ }^{21}$ Somewhere along the way the country got a little off track, and the protestors were trying hard to get it back.

This brings up an interesting point about how the protestors viewed America. Many thought God ordained America into existence. One protestor wrote, "I feel this country, the United States of America, was founded on God, religion, freedom, and God.... God is the voice our country was founded on. I am one of those people who believe when you step on God and my country you are stepping on the fighting side of me. Because you can't have freedom without 
God. ${ }^{22}$ The resolute belief in this ordination goes beyond patriotism and sweeps into the realm of nationalism. The protestors did not just love their country, they believed their country to be superior to all others. This leads to internally divisive political battles between fundamentalists and those who dare not to share their beliefs.

Social conservatives tended to filter everything through a religious lens. The constitution. The economic system. Everything. Protestors found ideological soul-mates on the national level. 700 Club co-host and Christian Coalition founder, Pat Robertson claimed the constitution was a “divine instrument.” “And that instrument ASSUMES, ladies and gentlemen, it ASSUMES throughout ALL of its pages the existence of God, the existence of the Bible, the existence of spiritual principles. And these men attempted, under God, to form a nation that was governed and ruled by eternal principles. They weren’t coming up with new things out of the sociological research of the latest professor of the University of Philadelphia. They were looking at the Holy Bible." ${ }^{23}$ The Book of Proverbs holds the basis for the free enterprise system, ownership of property, and business competition.

For social conservatives the family anchors everything. It is the foundation for culture and society. It is the moral compass for civilization. Rearing and character formation of the children constitute the most important duty of the family, especially instilling moral values. Since social conservatives view men and women as bags of sins, the only possible mortal savior is the moral authority the family and church provide. Rebecca E. Klatch further illustrates the social conservative's nature, "Accompanying this reverence for the family unit is fear of the decline or weakening of family life. The fear is that any attack on the family will ultimately cause the deterioration and collapse of all civilization. It is out of this need to protect the family - 
to maintain moral authority of society - that social conservatives view with dismay the affairs of contemporary America.”24

Wafts of communist conspiracy dispersed throughout the Kanawha Valley that year. Over a decade after the controversy, one of the movement's key leaders, Ezra Graley, remained convinced of a communist plot: "I believe it was all a Communist conspiracy, myself. Still do. And I'll believe it. That they was behind all that... I think it was apparent that it was either Communists or some of these parents that had grown up in the Sixties when they was burning the colleges and all this and was brainwashed. Our news media was very, very far to the left, and I still think so.”25 Graley touches upon two key points: the communist conspiracy and the radicalism of the sixties, which parents sensed as being the cause of the whole ordeal.

Plenty "Letters to the Editors" flooded into the Gazette and Daily-Mail, relating the same fears as Graley, but with more immediacy:

The Communists, no doubt, are trying to undermine the morals of our country and brainwash our young people against God through the textbooks so that they can take our country without firing a shot. ${ }^{26}$

These books are the second Communist act. The first was taking prayer and Bible out of schools. These books are to put devils in. ${ }^{27}$

A lot of us today are like that little Dutch boy. We are trying to hold back the floodwaters of communism but are not receiving (our) due for upholding our God-given moral rights. ${ }^{28}$

Nikita Khruschev (sic) said he would take over this country without ever firing a shot, be would do it through our children. Is this why these books are in the Kanawha County schools? ${ }^{29}$

Do you think your so-called education can fight the wars? Honey, if the Communists, take over, which they are, I bet they tell you and your children what to do. ${ }^{30}$

As irrational as many of their accusations appear, just dismissing their fear to ignorance does not 
help explain their actions. Protestors associated what they saw in the textbooks as being antiAmerican, with a Cold War mentality anything anti-American automatically translated into communism.

Since communism was the antithesis of America's capitalist society, it took the brunt of suspicion. Protestors still viewed communism as a major threat to all they held dear and sacred. It symbolized two threats. First, it marked the destruction of the family. Second, it promoted atheism. Communism destroyed the family by attacking the natural basis of relationships based on the elimination of any kind of domination. It tore down the natural hierarchy of authority, which is so central to the social conservative world. Social conservatives need a hierarchy. It just is, originating from Genesis. Without some sort of hierarchy, then God and man are on the same level. The commies’ treatment of organized religion scared many devout Christian-Americans. They demolished churches, killed or imprisoned preachers, and censored the Bible. ${ }^{31}$

"Because communism poses such a fundamental threat to assumptions regarding God and Man, social conservatives are fearful for the future of America. A godless society is conducive with the aims of the Soviets," Klatch continues, "the lack of faith and the perversion rampant in contemporary America leaves the country morally weak, dangerously susceptible to infiltration. A society that lacks moral integration is easily divided, ripe for Communist takeover.”32 Protestors expressed similar sentiments:

What our children will be taught in the future will cause a general corruption of all moral principles in which they have been nurtured. ${ }^{33}$

If we revolt against God and His order, civilization would lapse into barbarism. This is what is happening in the world today. Liberty is not freedom from law. That is recklessness. ${ }^{34}$

Our children belong to us and not the state. The schools are worse now than they 
have ever been. The public schools are brain laundries in which our children are being destroyed. ${ }^{35}$

Ours is a sorely troubled nation and I believe it to be on its knees. Readers, we are in grave trouble with God Almighty, and God walks softly and carries a big stick. $^{36}$

All of these letters display a suspicion of government organizational power or of any kind of big government commonly associated with communism, against the control of the state over the person.

They say the proof is in the pudding, and Kanawha County's custard bulged with communist conspiracy. The disputed textbooks included excerpts from prominent American writers such as e.e. cummings and Allen Ginsberg and famous, outspoken African-Americans like James Baldwin, Eldridge Cleaver, Dick Gregory, and Malcolm X (as told to Alex Haley). Most of these authors' works were only available through supplemental texts - books that were not required reading but there for the student's curiosity. Just by including such radicals like Cleaver and Malcolm X gave credence to their opinions and ideas about America, which posed a threat to the protestors' way of life. It scared a parent to think their son or daughter would read Soul On Ice, where Cleaver describes how in his youth he used to rape white women as an open act of protest, a way to revolt against white America. Who else but a communist would include such bologna, parents thought.

Objections to Cleaver's book strikes upon another theme of the controversy. Subtle racism appeared in many of the objections, especially in relation to works by controversial black authors. The fact remains the whole controversy could not shake this hint of racism, no matter how many times they said it was not about race. Parents balked at the idea "bringing the 
language...and the rebellious attitudes of the ghetto into the classroom.”37 Or more blatantly protestors described the books of African-Americans as "hellish” and "jungle-written.”38 One board member explained that what some of his constituents found objectionable about an elementary textbook was not so much the content but the cover: a white girl holding daisies with a black boy bending over to smell the flowers. ${ }^{39}$

The seventies was a time of racial quiescence when the racial movements of the previous decade seemed to wane. Racial oppression had hardly faded away, but conflicts over race receded as reforms were institutionalized. Over the fifties and sixties, a shift took place in the dominant paradigm of ethnicity. For the right, racial issues became central to their agenda. They reopened the sixties debates on racial identity and equality, questioning the role of racial issues in the democratic political process. Their success depended upon their ability to rearticulate the meaning of race in contemporary American society. ${ }^{40}$

The textbook controversy follows in the footsteps of this movement to rearticulate the meaning of race, something Michael Omi and Howard Winant label as authoritarian populism, which calls for respect for authority, mistrust of big government, and defense of traditional morality, with resistance to minority demands for group rights. Since they cannot rely on old patterns of racism, they rearticulate them. They use code words first developed by George Wallace. Phrases and symbols that refer indirectly to racial themes, but also veer away from directly challenge popular democratic or egalitarian ideals. So calls for community control or law and order are coded phrases meant, as with the former, to maintain the status quo in a segregated community or, as with the latter, to openly speak out against the problems associated with black ghettoes. ${ }^{41}$ 
In 1970, the West Virginia Human Rights Commission wrote about the strange paradox found within the state on matters of racial equality: "Whereas many West Virginians are now expressing opinions and displaying attitudes of greater understanding in race relations, whereas many persons express opposition to racial prejudice and discrimination, the actual picture in employment practices which reveal only token progress and as it receives reports of discrimination in housing which cannot be wished away by hopeful expressions of progress.”42 Discrimination still penetrated many different areas throughout the state in the years before the textbook controversy. Many schools in the county experienced racial disharmony including Dunbar High School, DuPont High School, and St. Albans High School. In 1969, fighting at Stonewall Jackson High School escalated to the point where the school closed its doors for several days until the tensions subsided. Schools still discriminated in terms of school clubs and participation as cheerleaders, majorettes, and homecoming queens. Black students at Huntington High School staged a sit-in, closing the school for two days. The students demanded the right for black-dominated organizations and black-originated organizations to be recognized as school clubs, a set percentage of black representation in the student council equal to the ratio of blacks in the school, educating blacks and whites in how to cope with present day society, a course on black culture, history, and literature, immediate reinstatement of all persons who have been expelled for modes of black dress, hair styles, etc., and the right to select popular methods of communication which would be helpful in educating and informing the entire student body as to the black population in today’s society as well as in our country’s history. ${ }^{43}$

In 1974, blacks in Charleston still faced discrimination and segregation. Ending segregation in housing proved difficult. Charles Switzer, director of the Charleston Housing 
Authority, said that there was still discrimination in housing, adding, "Basically, we live in a racist society.” No truly integrated neighborhoods existed in 1974 in any part of the city. Charleston's African-American population lived in all black areas of the city or lower-class integrated neighborhoods which were primarily black. From 30 to 35 percent of AfricanAmericans lived in low-income city housing. Though technically illegal to discriminate in terms of housing, the practice spread throughout Charleston, often as easy as just keeping the first black family from moving into the neighborhood. George Moore, Director of the Charleston Job Corps center, commented in 1974, “It's not a kind of 'white only' drinking fountain discrimination; it’s very subtle. Being white you would not notice it, but you can feel it in some places. There are some places in Charleston where blacks just don't go.” Supposedly urbane and liberal Charleston still suffered under the yoke of discrimination as other cities did at the period. $^{44}$

The National Education Association investigation found the textbook controversy to have a lot to do with race. The NEA concluded the protestors threatened the newly won rights of racial and minority groups to be included in the textbooks, and the protest was then, in part, a response to the growing black presence in America. Some African-Americans in the community saw it as such. Dr. Ronald English, pastor of the First Baptist Church, told the NEA board, "It comes on to the point of racist notions like that - saying that not only do we decide certain things about what you do and where you go, but we also take the prerogative of choosing your heroes. And since these particular heroes are not acceptable to us [the protestors], they should not be acceptable to you [African-Americans].... And I think that those kinds of statements and the unacceptability of certain kinds of writings are an expression of subtle racism.”45 Another 
African-American expressed similar views on the racism involved in the protests, showing some frustration about the lack of understanding shown by area whites, "White people ask me why couldn't there have been writings by the more respectable blacks. How many great respectable blacks do white people know? Probably none! If all the great blacks and their achievements were printed in the textbooks, white people would claim they were lies.... I think white people are afraid to let their children read writings by Malcolm X because they will learn the truth about the reasons why he preached so much hate.”46

Elmer Fike, prominent Nitro businessman and founder of the Business and Professional People’s Alliance for Better Textbooks, exemplified the white man’s lack of understanding of the black experience: "The only people who were racist were the blacks. I went to talk to them, and they nearly threw me out because I quoted a black author [George Schuyler], and that made them very mad. I went to the NAACP in Charleston and I said, 'I think you misunderstand us. We are on the same side of this thing as you people (author's emphasis).... They were committed to be against us.... I really felt the whole textbook thing degraded the blacks in many respects, degraded them terribly". ${ }^{47}$ The irony in Fike's statement is that most of the African-American writers were all for black empowerment, and to Fike their striving to gain empowerment degraded them somehow. His reversing the claim of racism demonstrates the kind of subtle racism (if not racism, then white arrogance) infecting the whole Kanawha Valley and affecting nearly all aspects of life from social to political, from schooling to housing. ${ }^{48}$

Besides the type of blacks portrayed in the language arts program, protestors also spoke out against the usage of "non-standard” English in the books. Non-standard English can be viewed as another code word, referring to African-American dialects that were found in some of 
the textbooks, linking the use of black dialects in the books with the black power movement. In the late sixties and early seventies, there had been a steady movement in the educational field to push dialects; scholars characterized "black English" as a unique dialect with its own structure and form. Many middle-class whites and also African-Americans scorned Black English as a lower-class, poor people's talk. Teachers worsened the situation by viewing the child's speech as bad and lazy, poor grammar usage, and punctuated with short jagged words. But modern linguists showed Black English to be a rigidly-constructed set of speech patterns with the sort of specialization in sounds, structure, and vocabulary as any other dialect. With this knowledge linguists and educators pushed for and received a bi-dialectal education in many parts of the country, hence black English (“non-standard”) appearance in textbooks. ${ }^{49}$

Charleston schools desegregated fairly smoothly, but that does not mean you can integrate everyone’s heart. Racial hostility swirled underneath the entire anti-text movement. Signs reading "burn nigger books" found their way onto storefronts. Some parents met an African-American teacher at a school dressed in white sheets. The future head of the West Virginia Ku Klux Klan founded his own anti-text group, Non-Christian American Parents. The Klan's involvement remains somewhat murky. The newspapers do not give them all that much press, but other commentators at the time tell a different story. "The KKK was brought in and is active in the problem,” writes Shirley Smith, “but the KKK isn’t getting too much newspaper coverage since there is feeling that discussing them will only encourage them." ${ }^{50}$ There were those who openly expressed their support of the KKK on the op-ed pages of the Charleston newspapers:

I am writing in defense of the KKK. Shame on you for passing judgement on a organization that is truly American and made up of God-fearing, good people. 
They are the only organization I know that stands for God and Old Glory enough to die for them. ${ }^{51}$

The NAACP praise Martin Luther King for his non-violence speeches and at the same time he cause more racial hatred, more riots, more fires, more property damage in this country than the KKK has ever done and to think some stupid organization gave him \$50,000 for a Nobel Peace Prize. All King ever did these things was for the publicity and money he suckered the people out of. ${ }^{52}$

Discrimination extended to other groups as well, like vociferous objections to a selection from Babi Yar. "Of course that's part of the approach they have,” relates an ex-Board of Education employee, “that the Jewish massacre really didn’t occur....That it was made up.”,53

Bashing intellectuals and elites opened up another stream of opposition for the protestors. A common thread of feeling saw that these intellectuals flexed their political clout in not only making these textbooks but in getting them adopted by the Board of Education. Some protestors displayed a genuine hatred toward intellectuals: “[Your Typical Left-Wing Weirdo] having lounged around in some left-wing college absorbing all his fancy philosophy from his equally slovenly professors. In short, he stands for everything that has been declared indecent, immoral, corrupt, degenerate, and unproductive. He is an anti-Christ plain and simple. He hates God. God will destroy him body and soul for his is the devil."54 To a certain extent their antiintellectualism had validity. These same "intellectuals" developed the educational program to attack the culture of poverty, which aimed at undermining the authority of the parents.

This antagonism towards intellectuals tells an important story in the backlash deriving from the sixties, which saw an increase in government bureaucracy and the rise of the technocrat. For a group of individuals searching for a more responsive government, they saw this bureaucracy and its intellectuals leaders as the enemy. West Virginia had direct experience with 
this increase in the government via the Great Society and the influx of VISTA workers who poured into the state. Anti-intellectualism proved to be just one way for the protestors to try and wrestle away power from the elites.

Allen Ginsberg, an outspoken, anti-war protestor, homosexual, beat poet, fills the role of Eastern, intellectual elite perfectly, but his autobiographical essay on his days at Columbia University irked many protestors. The essay chronicles Ginsberg's friendship with a red-headed whore and describes her pulling some tricks. A story like this quickly got labeled “dirty” or “filthy” by the anti-textbook crowd. Parents sifted through the hundreds of books, searching for any obscene word or inappropriate story. The books did not disappoint. Scrolls filled with goddamn's, hell's, bastard's, and so on. Protestors failed to see the beauty in e.e. cummings calling his pubic hair “electric fuzz,” but they did not stop there. They even assaulted classic children’s stories like the "Gingerbread Man,” “Three Little Pigs,” “Jack and the Beanstalk,” and "Pinocchio."

"Dirty" and "filthy" got thrown around a lot to describe the textbooks. Alice Moore first used the term, and after that everybody jumped on that bandwagon and started calling them dirty. The old standard, the McGuffey Reader, never used that kind of language, so the protestors thought why start now. More so than any other objection, the ones pronouncing the textbooks to be "dirty" or "filthy" harkens back to some idealized past where the protestors wished to return. The obscene in the textbooks exemplifies the moral decay of the country. Dope toking hippies infiltrated the system somewhere along the way and kept busy by corrupting their children. More so than the communist conspiracy theory, the labeling the textbooks "dirty" or "filthy" directly evolved from the sixties counterculture. That counterculture took form in the nations colleges 
and universities:

A few years ago the American Civil Liberties Union, with its Marxist revolutionary doctrine, succeeded in invading our college campuses with incendiarism, and hurling epithets at our social standards, jarring such things as God, family, America, cleanliness, and replacing the English language with their favorite four letter word vocabulary.... I fail to understand the reasoning behind the theory that seamy writings by seamy individuals, such as Cleaver and Ginsberg, can contribute to the education of anything. ${ }^{55}$

Parents could not believe that such morally bankrupt individuals would be allowed into the minds of their kids. Taking nearly half a decade, the protestors finally found an outlet to express their outrage over the disintegration of America’s character: “Just because half the world is on dope doesn't mean that I want a child of mine to experience it.”56

Tying into the obscenity in the books is the role of Christianity. What better than the Bible to be their spirit, shining a light on all shadow slowly stalking America. The textbooks spat on their spirit, their Bible, and its teachings. If one just dedicated their life to the Bible, then, many parents believed, that places you on the path to becoming a good parent and a good person. Schools allowed that path to grow over with weeds, and the textbooks only added fertilizer. The textbooks not only corrupted the children with commie propaganda and filthy language, but now they demeaned the Bible's teachings and the parent's right to raise their child in a Christian atmosphere. It is one thing to allow the filth to pervert the mind's of innocent children, but to allow this debauchery to demoralize the kid's soul is a completely different matter. You begin to mess with a realm where man is not king. Protestors held this to be true. During the sixties, America moved away from Jesus, causing, for the protestors, the country’s descent into a hellish oblivion. Sex, drugs, and rock’ n’ roll ruled, and until the restoration of God's work, this land remained condemned. 
The textbooks furnished Christians with more than enough objectionable material. The authors, not being content with publishing material suitable only for the corner skin theater, decided to include sections questioning God's superiority. This rowed up the protestors good and plenty. Now it became personal. Now they committed blasphemy. This appears to be a part of a growing trend in America, the desacrilization of society. Secular humanism, they call it, and it frightened the hell out of the protestors. Their battle against the textbooks was a much larger battle against secular humanism.

Originating in the late nineteenth century as a descendant of the rationalist philosophies of the Enlightenment, Christians shuddered at the thought of these secular devils gaining influence. Secular humanism argues that ethical behavior can flow from the human intellect and a self-conscious conscience. The philosophy’s attitude toward God and religion ranges from hostile to indifferent. The Christian Right for a long time latched onto this notion of a secular humanist conspiracy, for not only does it oppose God, but they believe it supports the devil and all evil in the world. ${ }^{57}$

To many social conservatives, humanism seeks the same goals as communism: a secular society based on one world government. Michael Edds, a youth pastor at the time of the textbook controversy, claims humanism to be a religion in itself, that "man was the ultimate, God is not. That was what was coming in, and we said, 'No you're not going to teach our children that., 58 Now secular humanist did not sit idly by while the religious right chucked rocks at them. They believed the Right to be using humanism as a euphemism for communism, a common scare tactic. Humanist, Sheldon Ackley, states, "Secular humanism is a hobgoblin for the people. It

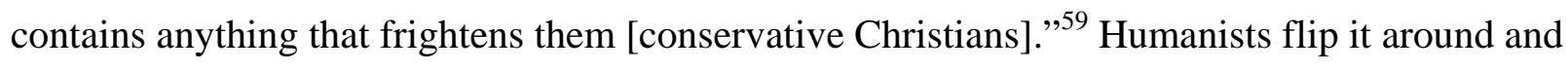


blame the religious right for trying to subvert education and stunting the educational growth of the nation's children. It boils down to a struggle between man and God, which becomes intensified by religion, since religion has long been one of the factors shaping American political culture and frequently injects a moral element into the country's politics. This perceived degradation of America's moral fabric has to be somebody's fault and always the top culprit secular humanism, for it is the perfect symbol of America’s path away from God.

The protestors held a negative view of human nature. One observed, "Every honest American will admit to himself that we have a natural inborn tendency to do wrong - not to do right. And I believe that the basic problem with the morals in these books is that the people who are writing them feel that there are maybe basic tendencies to do right, rather than to do wrong. And the problem is that people just don't do that. ${ }^{, 60}$ The specter of the first sin haunts mankind still. Man was created in God's image, but disregarded God's love for a life of temporary pleasure, making Man a sinner... fallen. Secular humanism holds a rather different view of mankind. They believe man is basically good and the master of his own fate. Humanist faith lies in Man's ability of self-improvement and the achievements of individual initiative. The philosophy denies the spirituality of Man, promoting instead the supremacy of the intellect, that Man can control his universe through reason and the mind. These attempts to create a heaven on earth are an apostation of God and his supreme law. Conservatives blame humanists for injecting self-centeredness and hedonism into the culture, with the belief that the only important thing is the here and now. The stress humanism places on the individual, without divine guidance and moral absolutes, produces a world without shared meaning or values. This, in turn, places doubts on authority and its sources, which the parents took serious offense to. With no shared value 
structures, then the child has a conflict of authority. ${ }^{61}$ One protestor writes, "At least the NEA... has made its 'bologna' report. The National Evil Alliance has one great goal, the changing of America to the new social order. The new secular humanism as opposed to Judeo-Christian way of life. One of its goals is the federalizing of our public school system as opposed to any state, county right. The parents are left holding an empty bag.”62

The common battleground between God-fearing Christians and the humanists has been the schoolyard. Right-wing Christians linked the trend of secular humanism in public schools with the growth in the power of the government in people's lives, the usurping of parental roles, and the supplanting of the churches as a moral guide. Fighters against the new textbooks were aware of the encroaching humanist influences. "I object to the humanistic approach to family life, and to moral behavior being taught by the schools,” proclaimed Alice Moore, who was more than well versed in the language of this struggle; "the secondary and elementary schools are being taken over by a humanistic, atheistic attack on God."63

Kanawha County lived through one of the first manifestations of this fight to combat secular humanism in an intensifying culture war. ${ }^{64}$ Protestors appeared deeply worried over this humanist intrusion into their schools: “The religious philosophy of our society...(has) three purposes: being a cloak to hide our true selves; being a club with which to clout our neighbors; a crutch necessary for those at the bottom of our social ladder.... I didn't expect you to want the children to be educated in a manner that calls faith a myth, who would then (come)...home and kick the crutch from under them., ${ }^{, 5}$ Protestors still smarting over the Supreme Court’s decision to remove prayer from schools lashed out at the textbook's perceived intrusion into their most personal relationship - faith in God and Jesus. 
While parents were resigned to the ban on school prayer, they could not abide by what some of the textbooks said about God and religion: they objected to Gwendolyn Brooks’s poem, “The Preacher Ruminates Behind the Sermon,” because it suggests God sometimes gets lonely and tiresome of his greatness; to Roger McGough’s “Mother, There’s a Strange Man Waiting at the Door," which portrays Jesus as a down and out beggar; and to any book that ridiculed faith, called Biblical stories fables or myths, implied moral relativism, or treated God as human. ${ }^{66}$ Protestors found particularly disturbing the elementary school textbooks that posed open-ended questions to children to think that they were God that referred to an Old Testament story as a myth, and told them to come up with their own myth. "[Some stories in the Third and Fourth grade textbooks] were trying to indoctrinate the children that their whole religious heritage was based on myth,” Elmer Fike continues; "there's no real basis. It is a real offense to destroy young people’s faith in a religion by referring to these as myths." ${ }^{67}$

Generally, protestors believed if the government kept prayer and other forms of religious expression out of schools, then the schools should also not be disrespectful a person's faith. Echoing the sentiments of many, one protestor said, "My contention is that if you can't have prayer or mention of God in schools, then he shouldn’t be mocked either." ${ }^{\text {,68 }}$ Another went on to explain, "If they wanted to stay away from religion, that was all right, but they were not staying away from religion. They were dabbling in religion and trying to destroy the religious feelings of the people in this community." ${ }^{69}$ Devil humanism reared its grotesque head, parents thought, in those pages of the textbooks. It was government run amok. As one protestor put it, “Our education system, once designed to improve our people has become a bloated, godless monstrosity."70 
This three-pronged attack (anti-American, obscene, and anti-Christian) waged by the textbook editors sent waves throughout the community, preying on their already entrenched fears and mistrusts of government intervention. By borrowing the same sort of populist rhetoric used by George Wallace, the protestors fought back against their foes. This grass-roots effort to rid the school of the textbooks that were anti-American, communist, filthy, dirty, and anti-Christian gained the attention of the nation. Their response, spurred on by the rapid changes in American society, which ultimately funneled their way down to Kanawha County, foreshadowed much of the conservative language, thinking, and strategy that came after. 


\section{Chapter Five}

\section{The Searchers: Building the New Right}

There's a shot at the end of The Searchers where John Wayne's character - Ethan Edwards - the loner, the hero, the man, is silhouetted in the doorway. As the last frames flicker on by, Wayne’s Ethan watches as close family friends scramble into the desert farmhouse, pawing over the rescued Debbie (played by a young Natalie Wood). He stands for a moment, legs shoulder length apart, left arm draped across his chest holding his other elbow, the wind blowing hard the brim of his hat, Stan Jones singing "Ride Away, Ride Away"; Wayne slowly turns and moseys toward the horizon - a man alone. The door shuts. The end.

Returning to his brother's home after a long and somewhat suspect war spent in the service of the Confederacy (Wayne shows up on the doorstep with a satchel full of freshly minted Union gold dollars. How he obtained them remains up in the air, but it is suggested that he robbed and killed for them.), Ethan is allowed a respite before Comanches appear and liberate some of a neighbor's cattle. A posse forms and follows in pursuit, but the cattle were just a diversion to get the men away from farmhouses. When Ethan returns to his brother's homestead all are dead and young Debbie is missing, presumed captured. This leads Ethan and an adopted quarter-breed to partake in a multi-year revenge-fest to hunt down Scar, the Comanch responsible for the murders. Wayne, a stranger to the world, sets out for justice, to make the world, his world, right again. 
It's the Duke's characters like Ethan Edwards that enamored him to the New Right. His swaggering, tough-talking loners embodied the very characteristic New Righters themselves tried to exhibit like duty, principle, and, as seen above, a deep sense of justice. Some like to think Wayne symbolizes America for the New Right. His unabashed patriotism and "love-it-orleave-it" belligerence tickles the New Right in all of the right spots. ${ }^{1}$

Wayne "gave the whole world the image of what an American should be," wrote Ronald Reagan. Reagan respected Wayne’s stance against communists, a stance admired by many New Righters:

In the 1940s, Duke was one of the few stars with the courage to expose the determined bid by a band of communists to take control of the film industry. Through a series of violent strikes and systematic blacklisting, these people were at times dangerously close to reaching their goal. With theatrical employee's union leader Roy Brewer, playwright Morrie Ryskind and others, he formed the Motion Picture Alliance for the Preservation of American Ideals to challenge this insidious campaign. Subsequent Congressional investigations in 1947 clearly proved both the communist plot and the importance of what Duke and his friends $\operatorname{did} . .{ }^{2}$

And his fight with Eastern elites, which foreshadowed the growing American conservatism.

The public jammed theaters to see... The Green Berets. The critics, however, delivered some of the harshest reviews ever given a motion picture. The New Yorker bitterly condemned the man who made the film. The New York Times called it "unspeakable...rotten...stupid." Yet Duke was undaunted. "That little clique back there in the East has taken great personal satisfaction reviewing my politics instead of my pictures," he often said. "But one day those doctrinaire liberals will wake up to find the pendulum has swung the other way. ${ }^{3}$ 
Writing shortly after Wayne's death in 1979 for Reader's Digest, Reagan demonstrates the sense of justice found in Wayne and his movies and close to the hearts of the New Right, which could serve as a motto for the New Right's political agenda:

"There's right and there's wrong," Duke said in The Alamo. "You gotta do one or the other. You do the one and you're living. You do the other and you may be walking around but in reality you're dead."

Duke Wayne symbolized just this, the force of the American will to do what is right in the world. He could have left no greater legacy. ${ }^{4}$

This "force of the American will” aptly fits with how the New Right viewed themselves and their struggle to change America.

They were beginning to express a dissatisfaction more general than merely education, but they didn't have the verbal skills to say so. Or perhaps they didn't have the ideological skills to say what was really bothering them. It was just a matter of someone came along, willing to fight. We were standing up for these people. Nobody was willing to get in there. ${ }^{5}$

- James McKenna

The textbook controversy came at a pivotal time in the development of the New Right and conservatism in general, representing one of the first outbreaks of a conservative, singleissue controversy that the New Right would harvest for their own purposes in trying to tear down party loyalties and building a constituency. Organizations associated with the New Right ideology, the Heritage Foundation, Populist Forum, the Conservative Caucus, cut their teeth in the Kanawha Valley, where they learned what will and will not work in the battle to gain control over the soul of America. 
So much about the New Right screams paradox. They call themselves the New Right, but really they rely heavily on Old Right arguments for economic libertarianism, anti-communism, and protection of traditional values. But the New Right shifted the language of conservatism, and in the process shifted the process of conservatism away from the elitist establishment of the Northeast to a more populist base that stretches across the entire country. They managed a sophisticated network, as Michael Omi and Howard Winant state, "The New Right was a wellorganized alternative to the moral and existential chaos of the preceding decades: a network of conservative organizations with an aggressive political style, an outspoken religious and cultural traditionalism, and a clear populist commitment.”6

George Wallace's campaigns of 1964, '68, and '72 acted as revelations for New Right strategists, who would jump on the opportunity to usher these constituents into the Republican Party - a Republican Party they tried hard to shape in their image. But how? In a menacingly complex twist of fate, the New Right was and always has been an organization without organization. To label something New Right would be doing just that: labeling it after the fact. Sure some consider themselves to be New Righters like Richard Viguerie and Howard Phillips, but the New Right remains more metaphysical than concrete - an ideology. They managed to establish themselves as the most dynamic force within the Republican Party by exploiting events such as the textbook controversy. A populist image formed around them as they spoke to and for a large, disgruntled slice of the American population. By using a smattering of organizations like the Heritage Foundation, the New Right molded and forged a new constituency. The people at the heart of textbook controversy provided them with just the right kind of opportunity for the 
New Right to test its new strategy for power.

It is hard to tell when the New Right, the political activist group, began. No exact time line exists for the New Right's emergence. No galvanizing event shaped their being, but rather a series of events occurring over the span of decades fashioned the New Right's philosophy, with the textbook controversy being just one cog in the growing New Right political machine.

The roots of the New Right can be traced back to the birth of the nation. The traditional fluidity of the American social structure has caused the problem of status displacement in American life. Any number of new problems encroached on the old, leaving a fertile breeding ground for populist right-wing (as well as left-wing) movements to rectify society’s ills. The forcing of conservative elements to operate in this climate meant they began stressing individualism, which lends itself to a moralistic approach found in much of the New Right's political platform. Seymour Martin Lipset and Earl Raab label this ideology political monism, “This moralistic approach, already built into the American version of individualism, has always been conducive to the development of the conceptual model of political monism.”7

Writing prior to Lipset and Raab, Richard Hofstadter devised the paranoid style in American politics. Mostly dealing with conservative practitioners, the paranoid spokesman in politics inhabits a hostile national culture or way of life. So they see their struggle against the vile forces as outstanding patriotic acts deep-fried in righteousness and moral indignation. Absolutes encompass all of the decisions. There is good, and there is evil. Definitive, unshakeable answers to moral questions are given, leaving very little room for debate. ${ }^{8}$ Both the monism of Lipset of Raab and Hofstadter's paranoid style share many characteristics with the 
New Right, and the three bring out the deep historical footprints of right-wing movements that were at work with the evolution of an ideology like the New Right.

Contemporary historians have raised some issues with Lipset and Raab and Hofstadter's arguments. They name a long list of grievances about the three: discounted nativist beliefs and conspiratorial inclinations of the ideological mainstream, underestimated the effects of social change, inferred the illegitimacy of cultural as well as class conflict, reduced dissident ideas to psychological symptoms, and often invoked fascism or Nazism when discussing the Far Right. Alan Brinkley places the three in the consensus school, which sought not to explain the elitist Right but the grassroots support they received. But consensus scholars' explanations suggested that conservatives and their ideas and grievances should not be taken all that seriously. This produced a dismissive view of American conservatism, which tended to see conservatism as a kind of pathology, some sort of irrational and unconscious influences upon political behavior. ${ }^{9}$

Brinkley describes the New Right faction of contemporary conservatism as fundamentalist, whose demands are more radical and whose critique of modern society derives from a deep-seated cultural and religious fundamentalism and not from elitist notions of tradition and morality. The rise of the New Right creates a challenge for historians and social scientists alike in "understanding and explaining a phenomenon so profoundly at odds with what many Americans have come to believe are the uncontested assumptions of modern Western society."10 Brinkley uses fundamentalism to portray not simply those with fundamentalist religious beliefs, but a larger segment that wishes to purge American culture and politics of any involvement in relativism or is anti-traditional in character. Resurgent fundamentalism took most liberals by 
surprise, with their attacks on secular and scientific values of modern culture, which liberals considered to be the norms of modernity. Leo P. Ribuffo counters Brinkley by arguing the Right cannot be brought into the historiographical mainstreams while terms such as "political fundamentalism” get tossed around or overwrought delineations of a timeless conservative tradition are used. For Ribuffo, the modern Right can be traced down the nation's history through a series of patterns of belief and behavior. Though, Ribuffo fails to differentiate between the different strands of conservatism and the internal ramifications these divisions would have on conservatism.

No clear spilt existed between the old and new right. Much like the cracks in the dam, they are always there and grow bigger, but one's not responsible for the flood. One crack spread throughout Orange County, California. There in the early sixties the people of this Southern California community reacted against a wayward culture and the unresponsive government that allows such heathenism. Lisa McGirr explores Orange Countians responses in her Suburban Warriors. The work touches upon the duality of modern American conservatism, with its concoction of traditionalism and modernity, which suggests the adaptability, resilience, and intractability of the Right in American political life. ${ }^{11}$ The newly affluent men and women of Orange County expressed their worries of the loss of autonomy of their neighborhoods, the erosion of individualism, the authority of the family, and the place of religion in the national landscape. This mobilization of the Right came as a result of the conservatives' lack of influence in Washington; as McGirr states, "Moderate Republicans had triumphed under Eisenhower, and old-time spokespersons of the Right, such as Robert Taft and Joseph McCarthy, had died.”"12 
Orange County conservatives argued the move away from true laissez-faire capitalism ate away at the soul of America, causing much of today's problems. In doing this, they fabricated an attack with a strong emphasis on the free market and social conservative values of family, morality, and religion, which validated their own lives and success, explained their discontent, and infused a strong sense of cohesion and community. "Orange Countians - and eventually also the national normative conservatives and their emphasis on religion and order with the freemarket radicalism of the libertarians."13 The merging of these two elements - libertarianism and social conservatism - is key for the development of the New Right, and Orange Countians completed the Holy Trinity for the New Right by espousing their vehement anti-communism, which created the glue that held the three together. The dreaded communists provided both the libertarians and social conservatives with a shared cast of villains. These three elements would be the key for the New Right and provided the focus upon which they would base their attacks on the establishment.

Direct mail guru Richard Viguerie sums up the feelings of New Righters in what they felt was a need for a new direction with a new set of individuals:

What these critics were recognizing, whether they fully realized it or not, was that conservatism had broken loose and was spilling out over the old party boundaries. Conservatives, at long last, were building independent constituencies and pressure groups to match those of the liberal coalition. The Republican Party was no longer a 'reservation' where conservative concerns could be conveniently segregated. Pro-lifers, gun owners, religious groups: each of these now developed its own base. No Republican "Uncle Tom" could bring them down to suit the liberals, who owned the plantation. ${ }^{14}$

Finding a constituency plagued the early New Righters in their efforts at influencing 
national directives. They knew a constituency, a powerful constituency, existed out there. It just needed to be mobilized; the only problem was that the constituency extended across both party lines. George Wallace showed how successful a populist and conservative message could be. Maybe the election of 1968 would have turned out differently if Wallace grabbed the Democratic nomination away from Hubert Humphrey, or if Ronald Reagan campaigned for the presidency then instead of a decade later. Wallace forged a powerful rhetoric that attracted many of his fellow Southerners, as well as blue-collar Northerners. ${ }^{15}$

The populist rhetoric of George Wallace provided a much-needed voice for New Righters, a starting point to corral a constituency. The Old Right, which owned controlling interest in the Republican Party for much of the Twentieth Century, made their keep by emphasizing anti-communism and free enterprise. But as the sixties rolled on the GOP of old began to seem out of touch. New rights-based liberals took to the streets, and they produced results, which left millions disconcerted. America had reached a fork in the road, and the balance of society was left in the sway. The Old Right seemed reluctant to do anything about it. This failure to care about the soul of America, seemingly led disgruntled conservatives on a mission to find salvation for America. Eventually, this would become the New Right and their cause would be social conservatism, separating the new from the old.

Wallace's rhetoric evolved from a racist subtext implicit with coded populist appeal. Wallace struck certain chords that anticipated the New Right agenda - defense of traditional values, hatred of 'big government,' and patriotic and militaristic themes; “the centerpiece of his appeal was his racial politics. Wallace was a law-and-order candidate, an antistatist, an inheritor 
of classical Southern populist traditions. He called for the stepped-up use of force to repress ghetto rebellions, derided the black movement and the War on Poverty, and attacked liberal politicians and intellectuals. Wallace departed from his early 1960s style, however, by avoiding direct race-baiting. ${ }^{, 16}$ His dangerous rhetoric showed the New Right the power found in code words, enabling them to tap into the fears of Middle Americans, code words such as forced busing, abortion, gun control, permissiveness, gay rights, women's liberation, the surrender of the Panama Canal, reverse discrimination, etc. These words were specifically used to have maximum effect and allowed the New Right to feed on the discontent, anger, insecurity, and resentment and to flourish on backlash politics. ${ }^{17}$

The New Right’s racial policy relied heavily on code words. On the surface, it was supposed to be a color-blind vision of society, where racial consideration was not considered in the selection of leaders, in hiring decision, and the distribution of goods and services in general. The Right believed, from the seventies on, that new forms of racial injustice had begun being perpetrated. Racial minority groups were granted a new form of privilege - preferential treatment. The state had gone too far. Its legitimatization of group rights, affirmative mandates, and money spent on social problems, which debilitated rather than uplifted, pulled the old switch-a-roo on racial discrimination affecting whites heavily, particularly white men. According to Omi and Winant, the New Right rearticulated the meaning of racial equality by their use of code words to mobilize those threatened by minority gains. So they set out to dismantle the political gains by minorities. ${ }^{18}$

With Wallace's revelation of an apt constituency, the social conservatives went a- 
courtin'. The Democrats led the assault on the family; the Republicans just allowed it to happen. So the New Right's gaze fell upon the Republican Party to try and reform America, but it would be a struggle just to gain influence within the party. The Republicans' apparent lack of interest in the direction of the country disgusted many New Righters. Viguerie notes, "The Republican Party could have made tremendous capital out of the public's disgust, but was unwilling or unable to do so until the New Right showed the way."19 Some conservatives contemplated a third party or taking over Wallace’s American Independent Party. Wallace had hired Viguerie in 1972 to take care of his campaign debts, and there were rumors in the air about a possible Wallace/Reagan ticket in 1976. But the GOP was an institution, permanently established in Washington. It offered automatic legitimacy to those associated with it, but it would be murder to pry influence away from the traditional party leaders. ${ }^{20}$

The political upheaval of the sixties provided just the opportunity needed for a shift to occur. During the sixties, Democrats and liberals held the initiative. The differing factions bickered amongst themselves, creating a power vacuum. Liberal, moderate, and conservative Republicans spent the decade vying for this control of the party. The Barry Goldwater campaign of 1964 marks a transitional point for the Republican Party. Throughout the primary season, Goldwater's cronies took over party organizations in state after state, purging longtime local leaders who offered up questionable loyalty to the conservative cause, creating a nation wide conservative infrastructure, but his blowout defeat to President Lyndon Baines Johnson left the Republican Party open for different factions to compete. In the mid-sixties, Republicans were an unevenly balanced equilibrium between three factions on a roughly right-center-left spectrum - 
the ideological conservatives, the Republican Party regulars and traditional conservatives, and the Republican moderates. The 1968 election nomination fight among Reagan, Richard M. Nixon, and Nelson Rockefeller was perhaps the classic expression of this alignment. ${ }^{21}$

The election of Nixon in 1968 was not so much a transition into a new Republican era, but more like a coalition between party regulars and moderates, even though he did co-opt some of Wallace’s thunder with his “Silent Majority” speech. Still, Nixon inspired many conservatives only to let them down, like Howard Phillips:

Nixon was someone who inspired extraordinary loyalty on the part of Republican partisans. He was a quintessential Republican leader. He, more than any other figure of his era, was able to articulate the aspirations of grassroots Republicans and to personify their hopes for the future in terms of policy. And his comments, for assuming the Presidency, but to focus on the core principles in which we have invested our hopes - and the policies, which arise from those principles.

I, for one, even then a very strong conservative, had hopes and expectations that Nixon would be a highly effective, unpredictably influential force for conservative policy. I was badly mistaken. And one of the lessons I learned from the Nixon era is that we need not to place our trust in Princes, but to focus on the core principles in which we have invested our hopes - and the policies which arise from those principles....

I came to realize that there was a huge disconnect between that which was said and that which was done. I observed the most outrageous examples of nonfeasance, misfeasance, and malfeasance within the Nixon administration - and the president himself has to be held ultimately accountable for what he permitted and authorized - presided over the disbursement from the Federal Treasure of billions of dollars to persons who in many cases were avowed Marxists, to persons who were promoting abortion and homosexuality....

The changes which we witness in American society today were the result of policies initiated during the administration of President Lyndon Johnson, policies which were consolidated, reinforced, validated, and extended during the administration of Richard Nixon. 
When I began my tenure in the administration, my presumption was, "If the president only knew about these things. If he only knew that they were funding Angela Davis, Jane Fonda, the Republic of New Africa, and many other things worse than that, that he would immediately correct it.” The ultimate revelation was that he knew and he didn’t care. ${ }^{22}$

Nixon wound up shitting in his own nest with Watergate and made the party more susceptible to ideologues found within the New Right, who became particularly enraged by Gerald Ford's pick for Vice President, Nelson Rockefeller, the epitome of the New England elite.

Besides creating the opening for conservative forces to gain a standing in the national party leadership, Goldwater also paved the way for future New Right campaigns. First, the '64 campaign implemented the "Southern Strategy" for one of the first times. The support they received in the South showed the region had a strong conservative base willing to vote Republican and that it was ripe for a Republican takeover. The South had long voted Democrat, but the turmoil of the sixties, especially the civil rights movement, and Wallace's presidential runs loosened party affiliations. ${ }^{23}$ Goldwater's electoral showing represented the absolute hardcore of the Republican Party - the diehards who you can always count on come election time. He received around twenty-seven million votes that November. Goldwateristas presented their political arguments to a national audience and created a foundation for future growth.

The campaign introduced conservatives to one another creating a network of contacts providing conservatives a foundation to build upon. Future leaders of the New Right paid their dues working for the Goldwater cause, many as members of the Young Americans for Freedom. In fact, most of the Goldwater campaign operated outside of the bounds of the normal party 
apparatus. The Republican establishment compelled conservatives to build a solid network of volunteers, who were well trained and prepared for the next battle. Lastly, Goldwater's campaign spawned the birth of direct mailing. In the decades to follow this would prove to be the calling card of the New Right. Up to that time, Goldwater received more contributions (most of them small) than any other presidential candidate. Up to seventy-two percent of individual contributions to the campaign were under $\$ 500$. Well-crafted letters found their way to the four corners of the country thanks to a sizeable and ever-growing mailing list. Direct mailing solved two big problems: communicating with the voter and solicitation of funds. ${ }^{24}$

The two elements needed for the ascendancy of the New Right were in place: a disjointed Republican Party and a means with which to communicate with the people. Now they needed someone to communicate with and issues to stimulate their growth, which were many: Equal Rights Amendment and feminism, drug use, pornography, busing, affirmative action, gay rights, and school textbooks. Single-issue politics became the norm during the seventies, and a group ideologically sympathetic to or affiliated with the New Right went to these groups to offer their assistance and many accepted.

The New Right thrived off of single-issue politics like the textbook controversy. These local outbursts proved to the leaders that their social conservative message had a place in America's pluralistic society. The New Right would carefully cultivate issues like that of textbook selection, forced busing, abortion, etc. What the New Right handlers quickly figured out was these separate single-issue groups were compatible: Viguerie comments on this in The New Right Papers, "Contrary to the myth that single-issue groups were fanatical extremists, each 
group was able to come to terms rather easily with the others. The pro-life and the anti-gun control groups had no conflict with each other that might prevent them from unifying behind one candidate." ${ }^{25}$ In the spring of 1975, hundreds of Kanawha County parents, who were involved with the textbook controversy, teamed up with Bostonian anti-busing protestors to march on Washington, with some careful coaching from a New Right affiliated organization - the Populist Forum. Emphasis was placed on building a broad coalition, a coalition not so much based on geography like the old New Deal Coalition but a new ideological coalition.

Basing their ideology on social upheaval and protest, not so unlike the movements of the sixties, some believed the New Right's objective pointed more towards unrest rather than governance. The repeated goal of the New Right has always been building a new majority, a grand coalition, which would no longer be encumbered by sentimental allegiances to outmoded institutions like the Republican and Democratic parties. They knew that millions existed out there who were instinctively New Right, just waiting for the opportunity to be unshackled from their traditional loyalties and ignorant of the choice for freedom the Right offers. ${ }^{26}$

They implemented this strategy in winning the Wallace constituency. They did so by stressing and supporting the socially conservative single-issue outbursts throughout the country. This invariably turned them into the most dynamic force in American politics. Their fascination with social issues have led some to proclaim a culture war has engulfed America: "Culture war controversies are distinctive because they are rooted in deep-seated moral values. In each of these controversies, at least one party of the conflict is mobilized largely because proposals or existing practices are viewed as an affront to religious belief or a violation of a fundamental 
moral code.”27 At the heart of many of these culture battles are religious beliefs Judeo-Christian in nature - but not usually specific doctrinal issues, but rather over the "most fundamental and cherished assumptions about how to order our lives... and our lives together in this society.” As James Davison Hunter states, "Our most fundamental ideas about who we are as Americans are now at odds." ${ }^{28}$ So issues invariably get tinged with religion, even though on the surface they may not be overtly religious in nature like the textbook controversy.

In this is a struggle over America, many on the "conservative” or "Evangelical” Right attempt to bolster their position by making it a religious venture. Give them the advantage of having God on their side, and they remake America's past and founding fathers into something of Christian saints - evangelicals to prove what the Founding Fathers had in mind were exactly what their (modern conservatives') agenda states. ${ }^{29}$ Faith performs many functions during a culture war. It unifies both public and private cultural symbols and infuses those symbols with universal significance. Faith acts as a moral guide, giving cultural conflicts their intensity. ${ }^{30}$

It has largely been a battle over the family and the child is at the center of every household. The family assumes an integral part for the New Right agenda. By association the school is thrust into the center of these cultural battles. Education manifests itself as the central institution by which social order is produced. The curriculum, textbooks, everything about the school transfers the symbols, which form the essence of America. The school then integrates the young into the nation's public culture. Public schools are also the most intimate contact most people have with government, and when the school goes wrong the government has gone wrong. Families have generally been responsible for the moral instruction and behavior of their children, 
but throughout the twentieth century, schools and social work agencies have come to define what is and what isn't in the child's best interest. The weakening of parental control in favor of a humanist ideology sparked most of the New Right's educational agenda, an agenda based on the belief that the parents were the supreme overlords of their children, and it was they who should determine what sort of moral and religious values their children will be taught. It is within this setting that New Right organizations came to Kanawha County to fight along with the parents. ${ }^{31}$

One of the first outsiders to get involved in the textbook controversy came from the Washington-based conservative think tank, the Heritage Foundation. Formed by Joseph Coors and New Right political strategist Paul Weyrich in 1973 with a gift of two-hundred and fifty thousands dollars from Coors, the Heritage Foundation gained nationwide attention and political clout under Reagan. A crack Heritage Foundation research squad produced Mandate for Leadership: Policy Management in a Conservative Administration, which served as a blueprint for Reagan's early agenda. ${ }^{32}$ The think tank set out "to formulate and promote conservative public policies based on the principles of free enterprise, limited government, individual freedom, traditional American values, and a strong national defense. ${ }^{33}$ In 1975 as a result of the Kanawha County textbook controversy, the Heritage Foundation created the National Congress for Educational Excellence to coordinate activities amongst hundreds of textbook protestors. With this organization the Heritage Foundation and the New Right now had the structure to capitalize on the feelings of many whites that felt their values and lifestyles were at risk from 'multicultural' texts.

James McKenna represented the Heritage Foundation in Kanawha County. The 
Foundation recruited McKenna after he ushered through a string of cases where he defended the rights of home-schooled children. McKenna, legal counsel for the then infant think tank, offered up his services, saying he’s just “a fella who rides around trying to make sense of an insane system. ${ }^{34}$ Kanawha County acted as a testing ground for the year-old public policy research institute, for the textbook controversy marked one of the first forays the Heritage Foundation made into the realm of politics.

The Foundation acted as a go between for the protestors. McKenna delivered the new set of demands by the parents to the news media on October 7, which called for the total removal of all controversial books; the resignation of the superintendent; the resignation of the Board members who voted to purchase the books and member-elect Stump; a review of all other books in the school system by a committee of seven people - four parents selected by the protestors and three by the school board; an investigation by the Governor of the selection and qualification of the state textbook committee; exoneration of all arrested during the textbook controversy; and no penalties to people off work or children out of school because of their feelings about the books. One can see the influence of the Washington lawyer in the scope and language of the demands. Previous demands were unfocused and sporadic. McKenna provided much needed direction and advice, as well as media coverage and free legal counsel.

The Foundation also provided free legal counsel and money to the anti-book cause. McKenna helped bail out imprisoned ministers and other leaders of the book rebellion. Illinois Congressman Phillip Crane in a letter spoke of the Heritage Foundation's legal assistance to the protestors and the breadth of the movement: 
The Heritage Foundation in Washington is helping the parents of Charleston regain their right to control the education of their children. Through the legal assistance of their lawyers, Heritage has been in Charleston courts defending protesting parents who have gone to jail for their beliefs.... Heritage has received inquiry from other parts of the country where parents share the same concern as the Charleston protestors. Legal action may be undertaken in those places.... I sincerely hope you will be able to help Heritage stop forcing pornography and other objectionable subjects into schools all over America. ${ }^{35}$

McKenna also saw the larger ramifications of the protestors’ actions, believing it involved the larger issue of parental control, saying, "The only thing that matters here is that the parents want them out.... If the parents call for them to go, they have the right and they should go.” McKenna goes on to explain the Heritage Foundation's motive behind becoming involved in the fight in Kanawha County: "Picking your fight is important. If you pick the right fight at the right time, it can be profitable.... You can make your political points. You can help the people involved, and you can become a force in the political community.”36

Outside of the Heritage Foundation, another organization with strong ties to the New Right, the Populist Forum, impacted the textbook controversy. Founded by Robert J. Hoy and Robert W. Whitaker, the Forum spent several years channeling the energy and resentment of numerous sporadic uprisings against the establishment into some kind of enduring alliance, including the textbook protestors, the opponents to busing in Boston, wildcat striking miners, and despairing farmers. Hoy envisioned the Forum "as a vehicle for unity - a catalyst for unifying those we had brought together." ${ }^{\text {,37 }}$ Whitaker called it the most effective group he ever ran, and he went on, "It provided press conferences and other representation to genuine grassroots protests. Independent trucks, anti-busing protestors, and textbook protestors, among 
others, were working people who were fighting well-organized forces. We would call up and ask if they needed someone to do their writing for them. In the case of a real, grassroots movement, it was what just they needed. They were new to the political wars, and all the experts and wordsmiths were on the other side.,38

The Populist Forum provided just that during the textbook controversy. They helped maximize national media coverage for the protestors, and persuaded the parents to take their grievances directly to Washington. The tactics worked as shows of support came from all over the country; the Kanawha County protestors stood for the values shared by many. Hoy and others would go on to plan three marches on Washington in 1975 after the initial conflict cooled and in conjunction with the anti-busing parents from Boston. An estimated 15,000 people attended all three demonstrations. The Populist Forum helped bring the textbook controversy out of the Kanawha Valley and into the rest of the nation, providing a much needed spark for other conservative social movements. ${ }^{39}$

Along with these groups, individual outsiders became involved with the textbook protests. Janet Mellon helped draw further national attention to the controversy. McKenna describes her as an "expert controversialist. She was well-connected - her husband was related to the money family - and a knife-fighter of some considerable proportion. She brought in a number of educators, writers, and controversialists and got them writing about the subject." ${ }^{40}$ Elmer Fike called on Larry Pratt to help his organization, Business and Professional People’s Alliance for Better Textbooks, map out a long-range strategy. Later, Pratt would be forced to resign as Pat Buchanan's campaign manager in 1996 after he was accused of having ties to white supremacist 
groups and the militia movement. The Gablers - Mel and Norma - were longtime textbook hawks out of Longview, Texas. Since 1962, they deconstructed every textbook up for consideration in Texas schools, going line-by-line, searching for objectionable material. In the Spring of 1974, Alice Moore contacted the Gablers asking them for assistance. They provided Moore with a bill of particulars from the textbooks, which had already been reviewed by the Gablers. Mel Gabler made the trek to Kanawha County to speak at a large anti-textbook rally at Watt Powell Park on October 6, 1974. Also speaking at the rally was Robert Dornan, who came representing the Orange County, California organization, Citizens for Decency Through Law, which was founded by Richard Viguerie. He made numerous public appearances throughout the Valley and spoke for the protestors on a few radio shows debating those for the texts. Shortly after the textbook controversy, Dornan won the House of Representative seat from Orange County, serving from 1977-1983. As a Congressman, Dornan became an active participant of many New Right linked organizations. In 1996, he briefly entered the fray seeking the Republican Party presidential nomination. He campaigned on a social conservative ticket. ${ }^{41}$ Outside of traditional political groups, conservative Christians supplied the New Right with another key element: foot soldiers in the crusade against the growing immoral secular world. No other group benefitted as much from the rise and politicalization of Evangelicals and Fundamentalists than the New Right. On many of the hot-button issues erupting throughout the seventies, the New Right piggybacked on the support given by the leaders of the emerging religious right. This relationship between politics (New Right) and religion (New Religious Right) is complex, since the two appear to be one in the same on many different occasions. The 
textbook controversy perfectly displays how this complicated relationship evolved.

The same events shaping the white backlash and the New Right, also helped move the New Religious Right into action, like Roe v. Wade, the gay rights movement, and women's liberation. For the longest time conservative Protestants held tremendous political potential. Gillian Peele states in her work on the interaction between religion and politics, Revival and Reaction, that "religion has long been one of the factors shaping political culture, and it has frequently injected a moral element into the country’s politics.”42 During the 1970 s, conservative religious revivals swept across America. Right-wing tacticians seeing this shift went after trying to achieve a "cleansing of America” and rolling back the evils of the sixties. The moral questions raised by these new social issues began the realignment of these Christians toward the New Right movement and eventually the Republican Party. The potential for this previously underpoliticized New Religious Right lay in its pre-existing infrastructure - an essential element in mobilizing around political issues. Leaders of the New Right tapped into this infrastructure and into a vast constituency, gathering the components needed to build their movement. ${ }^{43}$

The rise of the New Christian Right mirrors the rise of the New Right and in many respects the two are synonymous. ${ }^{44}$ The New Right made conscious efforts to court voters like those affiliated with New Christian Right groups and churches. And the New Right exploited many events turning them into the controversies, which roused the ire of many conservative Christians, facilitating their movement into politics. It was (and still is) a symbiotic relationship. The New Right's political agenda relies heavily on the support of conservative Christian voters. While the New Christian Right needed the access to power the New Right provided to try and 
affect change in American society. The New Christian Right's own forays into the political process have had mixed success, take a look at Pat Robertson's unsuccessful bid for the Republican nomination for President in $1988 .{ }^{45}$

Structurally, the New Christian Right resembled the New Right. It was a loose coalition of groups and churches, with some of the groups (like Jerry Falwell’s Moral Majority, which grew to become a significant political force in the late seventies and early eighties before Falwell disbanded it in 1989) more organized than others. Robertson's own organization, Christian Coalition, remains a player in national politics. All of the leaders and groups represented a concerted effort to change America, to project their values and their beliefs onto their country. This involved an acknowledgment of failure of America's pluralistic society that it was responsible for producing the morally despicable state of affairs America found itself in during the seventies.

From this grew the notion that the country's founding fathers' beliefs were theirs and vice versa. This movement into active and aggressive participation into politics fed on the belief that the country was a manifestation of God. America was God's country. And Americans were God's people. If this were God's country, then they owed it to themselves as Christians to protect it and save it from a growing moral threat. The people and the beliefs had always been there, but they (Conservative Christians) did not act upon them. Then all of a sudden, Christians began expressing themselves politically as Christians on a mass scale.

The New Christian Right began forming throughout the sixties, but not until the mid-tolate seventies did the organization began making headway into the political world. The social 
restructuring of the sixties and the perceived secularization of society raised the awareness of millions of Christian-Americans who recoiled at the country's direction. As a result, mainline denominations experienced a drop in their attendance and more conservative Christian churches (evangelical and fundamentalist) witnessed a dramatic increase in their numbers. Part of this shift can be found within the mainline denominations themselves. During the sixties, mainline churches changed their organizational structure. Bureaucratic organization became more important to the operation of church bodies. The clergy gained more control over the structure and operation of the church, leaving the laity feeling isolated within their own churches. ${ }^{46}$ During the fifties and sixties, the bulk of mainline churches united to end segregation in America, which represented the sort of moral engagement with the world, to change society that appealed to the liberal clergy. After the civil rights movement achieved certain gains and lost momentum towards the end of the sixties, liberal clergy began speaking out against the Vietnam War. This proved to be too much for many of the Protestant laity who supported the war and the fight against Communism anywhere. They were loyal, patriotic Americans and could not comprehend this attack by their own churches against the country they loved, against the country God loved. A clash of two distinct views of Christianity came to a head in the late sixties and early seventies. For much of the twentieth century mainline churches supported the ideology behind the social gospel - a brand of Protestantism that put Biblical teachings to use in trying to solve the world's ills. ${ }^{47}$ More conservative Christian churches, as they became more active during that period, began emphasizing what has been called civic gospel, which involved the reemergence of old themes such as individual salvation and responsibility but with an added 
emphasis on the Bible as the source of the nation's moral principles. ${ }^{48}$

As Christians started to speak out, more and more politicians began to listen. With the textbook controversy, the protestors received support from many congressmen in Washington. Congressman Phillip Crane from Illinois wrote a letter on their behalf describing the Heritage Foundation’s involvement. Indiana Congressman Roger Zion met with protest leaders in December of 1974 in Washington, and then registered their complaints in the Congressional Record. ${ }^{49}$ On the national level, President Nixon, more than his predecessors, openly courted the Evangelical movement. Nixon had a close and very public relationship with the Evangelical preacher Billy Graham. He threw open the White House doors to hold weekly religious services, inviting some of the most powerful conservative leaders to head the services. Nixon initiated a new era of civil religion, making conscious and calculating use of religion as a political instrument. ${ }^{50}$ Politicians also began asserting themselves as Christians, like Republican Congressman John B. Anderson of Illinois, who delivered a fiery speech to the National Association of Evangelicals in 1974:

It was [the liberals] who denied the supernatural acts of God, confirming the gospel to the canons of modern science.... It was they who found financial support for architectural monuments to their cause. It was they who were the friends of those in positions of political power. They were the 'beautiful people,' we - you will recall - were the 'kooks.' We were regarded as rural, reactionary, illiterate fundamentalists who just didn’t know better.

Well things have changed. Now they are the 'kooks' - and we are the 'beautiful people.' Our prayer breakfasts are so popular that only those with engraved invitations are allowed to attend. Our evangelists have the ready ear of those in positions of authority. Our churches are growing, and there are withering.... They are tired, worn-out nineteenth century liberals trying to repair the pieces of an 
optimism shattered by world war, race riots, population explosion, and the spectre of world-wide famine. We always knew that things would get worse before the Lord came. ${ }^{51}$

Certain segments of the population wanted change, a change to put the country on a Godly path, and politicians were receptive to and, as seen above, even encouraged these calls for change.

But exactly where did these conservative Christians come from? Why choose the time they did to enter into the political arena? Some scholars have labeled this period as a new "Great Awakening” due to the heightened awareness of the human nature in religion. Amanda Porterfield in her Transformation of American Religion claims the late twentieth century experienced a post-Protestant Awakening, which swept across the country, challenging people’s social and psychological construction of religion. People wrangled over the strong, American tendency to define religion in terms of morality. Coming into vogue were new ways of speaking about religion and an encouragement of one’s own personal experience. New sects and interest groups arose and advances in religious learning were promoted along with the idea that religion should actively engage in worldly affairs. “This idea leads to activism,” Porterfield writes: "which creates the expectation that religion should be beneficial to society. This, in turn, encourages the idea that religion should be respected in whatever particular form it happens to take. It contributes to the general tendency of American religion to play an active role in society, not just by collective ventures but be defining personal morality in ways that encompass social responsibility."52 Conservative Christians were the prime benefactors of this new Great Awakening, which supported and promoted their entry into the political world. 
Along with this view of a Great Awakening, scholars point towards different reasons. Some believe the political emergence of pro-active conservative Christians was an attempt to resist the reifying, technicizing, colonizing forces that originate in efforts to deal with economic and political conditions. Activist fundamentalists, as they are called, can be understood as one expression of dismay over the increasing "technization" of the lifeworld and of politics. The family and religion stand alone as the last enclaves of communicatively structured interaction. The expansion of the state into the lives of the citizens accounts somewhat for the political activism of some fundamentalists, who call for a reduction of state intervention in the economy and in the family, placing them ideologically with Republicans. ${ }^{53}$

And yet, fundamentalists move toward more aggressive endeavors, which appear to be a social phenomenon. Fundamentalist leaders, backed by visible followers, began asserting themselves in efforts to shape social life in America in the name of morality. ${ }^{54}$ Typically fundamentalists veered away from involvement in worldly matters, but America had grown so immoral that they felt obligated to engage in a "teleological suspension of the ethical."

Modern fundamentalists shared certain characteristics with their predecessors of the 1920s; primarily, their existence centering on a negative reaction towards modernity. Fundamentalists were resentful of "intellectuals," "elites," and the media, all of whom were viewed as sleeping with the whores of modernization and who cared little for the traditions of the country. But they also can be viewed as the latest in a late-twentieth century movement of groups -- black, Chicano, Jewish, Catholic ethnic, homosexual, young, or feminist -- to find and assert their own set of symbols. These symbols are designed to assure a group’s power, place, 
and pride against the real or presumed threats of others. ${ }^{55}$

Leaders of the New Christian Right recognized the power of symbols and they were able to manipulate moral symbolism to gain political success. They managed to frame issues in such a way that there was no mistaking who was on the right side and who was on the wrong side. In this atmosphere, everything gets reduced to a struggle of right versus wrong, and symbols help raise consciousness, which mobilizes a sense of participation in a larger meaning and opens avenues into the political process. At the heart of the New Christian Right's strategy was the family, which was viewed as a means to recover a lost meaning and the past. Their tapping into their symbols garnered strong emotions and deep levels of meaning, which in turn was transferred into political action. ${ }^{56}$ Manipulating moral symbols was just one element of a larger strategy to attract voters away from the established political parties toward new conservative organizations. Much like the New Right, the New Christian Right consciously looked for issues people cared about and they advocated the political takeover of community associations. They helped tradition bound populations gain control over local school boards, community councils, and party organizations. Grassroots protests, like the Kanawha County textbook controversy, were the most prominent characteristics of the new conservatism that engulfed the country at the time. They helped attract the attention of secular political leaders and played an important role in the formation of the New Christian Right. ${ }^{57}$

This same infrastructure supplied the support structure needed by the protestors. Going beyond the religiosity of the parents’ grievances, yet building upon their deep religious convictions, the church played an integral part in shaping and prolonging the protests. All of the 
key leaders were local preachers: Marvin Horan, Avis Hill, Ezra Graley, and Charles Quigley. Much like how they were called into God's service, these ministers received the call from their flock to lead the protests. Chief protestor spokesperson, Horan, who was convicted of conspiracy to dynamite a local elementary school in 1975, tells how he became involved in the controversy, “All I do is sit at the house and people call me. It's the people as a whole that's involved. It's no[t] one person that's instigating this." ${ }^{58}$ Concerned parents repeatedly sang the praise of Moore's pious convictions and the leadership provided by area ministers:

It seems to me that Mrs. Moore has all the sound judgement and good common sense on her side. Her arguments are clean and precise and factual and are soundly grounded on established moral and ethical principles. ${ }^{59}$

To Mrs. Moore. Yours is a voice heard above the din created by the parasitic slobs and effete snobs...the voice of mother, concerned citizen and public official who is not afraid to an opinion. ${ }^{60}$

I have nothing but the highest respect for people like Alice Moore, Rev. Avis Hill, and all the others who have taken a stand against the evil and works of darkness in this troubled world - would to "GOD" he would give us more champions of the faith like these brave souls. ${ }^{61}$

One protestor went as far as comparing the leaders and other protestors to Christian martyrs:

“The 'few' people who will stand up for the truth are treated unfairly. But isn't that the way it's been even back in Bible times? The Christians fought and died for what's right." ${ }^{62}$

On top of leadership and direction, the ministers threw open the doors of their churches, providing a base of operation for protestors to direct their daily activities. These conservative congregations made it clear which side they were on by allowing protestors full access to the churches' resources. Lay preachers used the pulpit as a means of communicating the perceived 
evil within the textbooks. Church buses ferried picketers around to local businesses. Ministers actively solicited donations for the various protest groups. Also, preachers led the movement toward creating a new private school system based on Christian values. Little doubt exists that the full weight of the churches involved rested behind the protestors, enabling the protestors to prolong their struggle. ${ }^{63}$

Just what were these small churches? Protestors came from a wide variety of "rural folk churches” with names like Open Door Apostolic Church, Spradling Gospel Tabernacle, States Community Church, and Ohley Missionary Baptist Church. Some have described these small, fundamentalist churches as the most reactionary forces in Appalachia ${ }^{64}$ The origins of these small churches go back to the first settlers in Appalachia. In the mid-eighteenth century, the Presbyterian church was the most important body on the frontier, but by the late eighteenth century the Baptist and Methodist movements began gaining strength in Appalachia. The basic religious tone of Appalachia was set during the nineteenth century, which was marked by religious revivals beginning with the Great Revival of 1800-1802 and continued on uninterrupted, except by the Civil War, throughout the century. ${ }^{65}$

Both Baptists and Methodists gained a considerable number of members during the nineteenth century and quickly established themselves as the most dominant forces in Appalachian religion. The Baptists attribute their growth to their simple gospel, democratic congregational organization, and their election and dependence upon lay ministers, which best suited the frontier conditions. Methodists, on the other hand, relied on their circuit riders and a stress on free grace, a more attractive idea to the democratic frontier spirit than the Calvinist 
doctrine of the elect. Most of the religious groups in Appalachia during the nineteenth century were local autonomous organizations of a sectarian character. They guarded their local autonomy closely and bucked at attempts at affiliation with larger congregations or national churches. This sectarian nature of Appalachian religion has never really disappeared. Religious life has changed with the breaking down of isolation and some sort of prosperity, but it cannot shake certain vestiges of sectarian religion. ${ }^{66}$ The small churches involved in the textbook controversy were just an extension of the traditionally sectarian churches.

But theses churches performed important social and political functions. First, they helped low-income and rural Appalachians alleviate anxieties produced by growing social complexity, especially the inability to fulfill the expectations of the larger society. ${ }^{67}$ Secondly, the church became the primary source of identity for many, providing "a place, a source, of security in the face of poverty, disease, and the many unpredictable elements of life. ${ }^{, 68}$ By fulfilling these roles, the church created a solid rock upon which flowered a movement such as the textbook controversy, a movement stimulated by the churches' leaders and the faith of its followers.

The church's role in the community and in shaping the social lives of its members mirrored that of the church leaders during the textbook conflict. In addition, the protestors expressed devout religious convictions concerning the institutions and destruction of the government by heathen forces. "Government and family are divine, God-ordained institutions," wrote one supporter of the protestors. ${ }^{69}$ This belief in the ordination of government by God meant that the legislature and politicians should work towards upholding the virtues found in the Bible. While this notion was not new by any means, Evangelicals and Fundamentalists have 
been expressing this since the nineteenth century, but beginning in the sixties, these conservative Christians began the process of mass politicization. Helping them with their transformation was activists associated with the New Right, nudging these Christians towards their social conservative agenda.

The protestors' emphasis on religion, while mirroring the larger shift in America toward a more conservative Protestant theology in many aspects, originated from different historical roots than their ideological brothers. Their religious beliefs, from what they transmitted through interviews and their "Letter to the Editors," provides a prime example of some of the characteristics of traditional Appalachian religion. The examples given allows us to see how Appalachian religion meshed with the ideology of a larger, national conservative Christian movement.

Throughout the centuries, Appalachians have developed its own distinct religious practices and beliefs, which creates the core of Appalachian culture. Loyal Jones places religion at the top of his list of Appalachian values, saying, "One has to understand the religion of mountaineers before he can begin to understand mountaineers. ${ }^{70}$ Religion completely shaped Appalachians' lives, but at the same time they shaped their religion. An optimistic social gospel did not mesh with life on the frontier, where hard work did not always bring a sure reward. This led to a fatalistic attitude, which stressed rewards in another life. This placed an emphasis on being saved, accepting Jesus as one’s personal savior. Jones explains, "It was and is a realistic religion which fitted a realistic people. It is based on belief in the Original Sin that man is fallible, that he will fail, does fail.... Not only does man fail, but he is presumptuous, pretending 
to be what he is not, pretending at times he is God. But in spite of his failings and presumption, man is still save if he has accepted Jesus Christ.” Other values shared by Appalachians originate from their religious beliefs like individualism, self-reliance, personalism, modesty, and patriotism. $^{71}$

Agreeing with the heart of Jones’s claims, Deborah Vansau McCauley traces the roots of Appalachia’s “mountain religion” to a mixture of four different strands of religiosity brought into the mountains by white settlers: pietism, Scots-Irish sacramental revivalism, American Baptist revival culture, and plain-folk camp-meeting religion. Traits of all of these can be found in the area’s religion today, which McCauley calls the key to unlocking mountain culture. From the religion sprouts the Appalachian's values and worldview - its traditions. These traditions placed heavy emphasis on inner, personal religious experiences, a sensitivity to Divine grace that pervades all aspects of life. $^{72}$

Remnants of the frontier religion remained in traditional Appalachian religion. A strong belief persisted that the Bible is the Word of God and everyman could find the truth through the Bible without the help of a church or its preachers. Traditional Appalachian religion accentuates the purity of God-generated or God-instituted emotion or religious experience, unmediated by direct human manipulation. Religion for Appalachians has been a source of personal strength for those who were colonized and also serves as a means of resistance. Appalachians see the everyday world as one of power, where supernatural forces of good and evil operate. Their religiosity helps them gain access to that divine power that will defeat evil. Also, they believe their life transpires simultaneously in two dimensions of time: present and future, and on two 
levels of reality: the here and now and hereafter. Charles Lippy notes the latter elements are imbued with power by the knowledge that the future beyond this life comes on a higher plane superior to empirical reality. The empirical reality becomes the domain of evil in part because of the intrigue wrought by supernatural powers of evil. But just as important is that present evil can be identified, battled, and conquered, because one affirms the reality of a higher realm. ${ }^{73}$

One of Jones's more interesting traits that he ascribes to Appalachians is this sense of personalism. Jones writes, "We [Appalachians] will go to great lengths to keep from offending others, even sometimes appearing to agree with them when we in fact do not. It is more important to us to get along and have a good relationship with other persons than it is to make our true feelings known. Of course, this personalism is one of the reasons those who work for confrontation politics often fail in Appalachia. ${ }^{, 74}$ But Kanawha County proved to be the exception to the rule, by refusing to shy away from confrontation. They were not afraid of espousing their religious beliefs and judging others for their beliefs:

It's a strange thing to me that the Kanawha County Board of Education and others cannot understand that you are what you read. Dirty textbooks are a wicked seed that will grow a wicked mind, sprit, and soul. The Bible says as a man thinketh in his heart so is he. Carnal men read the Bible and reject it as the Word of God.... Evil takes the heart like time does concrete, the longer, the harder. ${ }^{75}$

Following the lead of other conservative Christians around the country, the protestors could not stand idly by and watch evil overtake their country, their children. They viewed these textbooks as evil incarnate, and part of their upbringing included recognizing evil and defeating it. So while Appalachians, in general, might decline an invitation to a confrontation, but their duty to 
God outweighs this hesitation at involving themselves in the political world.

Jones also lists humility and individualism as being dominant values of Appalachia that they don’t put on airs, they don’t boast, or extol their own virtues. The normal stance is to downplay one's talents and qualities and to not judge. ${ }^{76}$ Controversies as tense as the textbook controversy do not usually lead themselves easily to claims of humility, nor does the whole nature of protest, which relies on the propping up of one idea over another. But a peculiar sort of humility seemed to permeate throughout the protestors’ words. They maintained the absolute faith in what they were doing and the righteousness of their cause, but it was tinted with this traditional humility. "I am a Christian and I don’t feel all the preachers are doing their jobs. I know I am no judge, but the Bible does say to watch for false prophets in the last days.”77 Another protestor wrote, “I don’t know much about the Bible but in my opinion there is no comparison [to the Bible]."78 But pouring over the "Letters" it is not the strong sense of humility that hits you, rather an outpouring of a very resolute faith:

Let me remind you it is not what we think that matters it is what God says. You either believe God or you do not there is no intermediate state. If you do not believe God you are condemned already (John 3:18). ${ }^{79}$

The Bible is a holy book, God-inspired, and there are places, too numerous to mention, where it admonishes us to be, act, think, live, and dress and talk, holy and pure. WE read of wickedness all through the Scriptures in every form. But we also read of how God destroyed the earth with water because of such corruption. The wicked people got death, physically, and spiritually. And the "just law" which were Noah and his family, received life. ${ }^{80}$

One of the most known characteristics of Appalachians is their individualism. Since the frontier days, individualism and self-reliance have been admired by mountaineers. They were 
imbued with a strong sense of spiritual independence in terms of discerning the Word and finding out about God on their own, without ecclesiastical hierarchy, clergy, seminaries, and other institutions thought to be needed for religious life. The protestors’ independent streak shone through in a couple of examples. Primarily, the difficulty leaders had in corralling the protestors into a unified mass. When leaders called for a boycott of schools, not all of the protestors responded in kind. When Rev. Horan accepted the first Board proposal, the protestors vehemently rejected it. And even the decision to enroll their children in the newly formed private Christian schools was an act of independence. They resented being told what to do, by anybody, because they belong to God: "Our children do not belong to our government (but) they do belong to God who has given them to us to take charge of their growing minds. „81

This personalism can also refer to how they relate to God and the Bible, which leads to a few consequences one being a strict literal reading of the Bible and another leading to a very personal relationship with God. Theologically speaking traditional Appalachian religion has been very conservative. At its core is Biblicism, or the belief in the inerrancy of the literallyinterpreted Scriptures. Built around this are various creedal tenets: the Virgin Birth, Christ's miracles, physical resurrection, and others. ${ }^{82}$

As churches in Appalachian struggle with the issue of authority, personalism developed. Faced with a pluralistic religious context, many churches claim to be the true and/or only church, because they are the closest to the New Testament. They are guided by immediate inspiration, not by some arcane "tradition.” They respond as boldly and uniquely to contemporary culture as the ancient Christians responded to theirs, building on valued traditions while discarding or 
adapting those values which inhibit the Spirit's activity in the new age. Many see their churches as being pure churches, untainted by modernism, liberalism, and worldliness, solidifying their personal relationship with God. ${ }^{83}$

Some protestors in the Kanawha Valley demonstrated this trait. A few talked of God talking directly to them and that God was working through them. "I believe God is speaking to the Christian people of West Virginia," one protestor wrote. ${ }^{84}$ Another went on more specifically:

I have been praying and seeking the Lord. I have gotten an answer from him. I know he is writing this letter through me. I know the Lord hath spoken when things get to be as corrupt as this thing. It is then that God begins to move upon the nations with his wrath. His wrath is really stirred. I saw in the papers where God sent out his lighting and struck the Civic Center and he is getting ready to move again. With his judgements upon old Kanawha Valley. ${ }^{85}$

Not only in this letter does the author provide a description of the personal nature some of the protestors had with God, but it also contains two other key points: a strong premillennial leaning and why the protestors acted, which is paradoxical because the former seemingly would cancel out the latter.

In general, the Protestant Right has exhibited explicit premillennial traits and Appalachia is no exception. In their reading of history, the world will worsen in anticipation of the end of history and the Second Coming of Jesus Christ, who will restore order and beauty. Which leaves the question of why bother reforming America? The answer lies in America being elected by God to train evangelists to rescue individuals before the end. So premillennialists know exactly where history is going, and with this knowledge they appear to be empowered: ${ }^{86}$ 
God is real and He will help us win this battle if it is to be. If it is not to be, I will say it is the beginning of the end of the world. God won't sit back and let His little children's minds be corrupted. ${ }^{87}$

I say God bless Alice Moore for putting the public wise to the breakdown of morals...listen to me, Christian parents and good people, keep praying to God for help. I am sure He will hear the prayer and will help us in this battle. Hold on to Jesus, all you Christians, and keep praying for time is getting short and Jesus may come at any time. ${ }^{88}$

Somehow by knowing the outcome and knowing that America is God's country acted as a call to action for Kanawha County Christians, much in the same way the New Christian Right was propelled into service. As Christians, the protestors were acting on behalf of God against the corruption of his state and people. "This country was founded on religion, people running from the oppression of evil, but the evil relentlessly followed. Thus the conflict between Good and Evil continues.”89

Appalachians felt every human being worthy of salvation, meaning if they accepted God into their heart then they could be saved. Out of this comes the "born-again” phenomenon. Its foundation can be found in John 3:3: "No one can see the kingdom of God without being born from above [born again in some translations].” Being born again is a spiritual rebirth, salvation. For conservative Christians, born again often refers to an intense conversion experience, an encounter where the individual experiences the full power of God. While "born again” refers to this conversion experience, it also has been used to identify devout believers, true Christians, from those who had not fully given themselves over to the Lord.

Textbook protestors displayed their born again experience proudly: "These men need a 
BA degree in Christianity (Born Again degree that is). ${ }^{, 90}$ Others went more in depth into what it means to be born again:

There are truly only two kinds of people on earth today. The lost and the saved. To what group do you belong? Only you can answer that. Are you tired of living under a load of guilt and fear then read and believe.... I would ask the born again Christians to join in daily prayer asking God in his divine wisdom, with the convicting power of the Holy Spirit to touch the hearts of those who are advocating teaching the children from books that are contrary to his Holy word. ${ }^{91}$

May God have mercy on the ones that bring them to pass as these ministers that say those school books are all right. They are not all right and the Bible says it all through it. A man that is called to preach the gospel is not going to say they are all right unless he has never been born again. The Bible said you must be born again and as these times are upon us, search the scriptures and see just how true the Bible is. ${ }^{92}$

The authors above say the sort of things New Christian Right leaders wanted to be hearing. They were clearly painting this battle as one where they were definitive sides: right $\mathrm{v}$. wrong, good v. evil. Their born again experience allowed them to frame the textbook controversy in such a way. And those who haven't given themselves over to Christ were not true Christians. They just walked through life mouthing the Scriptures without ever knowing the tenderness of the Spirit nestled against one's heart and soul.

Thoughts like these reinforced the New Christian Right’s strategy of placing every decision within a context of Good vs. Evil, and in Appalachia this idea had deep roots in the religious beliefs. Churches were inclined to blame the world with providing opportunities and enticements for corrupting the family, or they blamed people for becoming too self-centered. Satan maintained a powerful presence in the church. ${ }^{93}$ Satan is up to no good all of the time, and 
he is down here among us working his evil magic. This left people concerned about what was of the world and what was of God. Things of the world attract natural people to them, which may lead them away from the spiritual, from the love of God. ${ }^{94}$

Coming early in the metamorphosis of the New Right, the textbook controversy set the early tone for the rest of the decade ending with Reagan's campaign for president. With the help of the Kanawha County cultural uprising and others like it, the New Right found their constituency. They found a group willing and ready to listen to their platform of family values, and a means with which to aid and communicate with these groups, giving the New Right that much needed support. With that support and well tested tactics, the New Right moved on from the textbook controversy to solidify their place on the American political spectrum.

When the parents decided to rebel in 1974, they had no idea the implications of their actions. Simply wanting to protect their children from a cruel and strange world, they did much more. The Kanawha County protestors symbolized the rising tide of conservatism that swept over the seventies. They lashed out against the social upheaval of the sixties, which produced so much they did not understand, so much they did not like. Responding with an upheaval themselves, the protestors mirrored other grass-roots movements manifesting in the seventies, grass-roots movements that helped shape the New Right and provide it with the support it needed to rise to prominence. How could they know what they were getting themselves into. 


\section{Conclusion}

As 1974 ended and tensions abated in 1975, the parents of Kanawha County toned down their protesting and life regained a sense of normalcy once again. But the reverberations of their actions would be felt long after. In the years following the textbook controversy, conservatives began growing louder and louder on the national political scene, culminating with the election of Ronald Reagan in 1980. The protestors emphasis on social and moral concerns would foreshadow the rhetoric of future conservative leaders like Jesse Helms and Orrin Hatch and played a large role in the election (and re-election) of President George W. Bush.

The textbook controversy seemed to occur at the nexus of this conservative resurgence. It displayed elements of the various ingredients needed for the Right to regain political power. The protestors' grassroots activism showed the way for future single-issue groups. They were extremely successful in disrupting the Kanawha Valley and forcing the Board of Education to deal with them. By using some of the same techniques patented by the very groups they were protesting against, the protestors marched, picketed, and boycotted their way into the national press, in the process, gaining the support of and speaking for a large segment of the population that feared the direction the country was headed on.

During the 1960s, America underwent tremendous social and political changes mostly brought on by liberals. African-Americans began asserting themselves and their rights, as did women and homosexuals. This left many Americans uncomfortable. The country they loved was 
being overrun by the people that seemed to hate it the most. But there were those who spoke out like Alabama’s Governor and perennial presidential candidate, George Wallace, and Maryland's Governor and Nixon's Vice-President, Spiro Agnew. They would be the ones spearheading the political backlash against the social upheaval of the 1960s, while people like the Kanawha County protestors were expressing their disdain for the changes of the 1960s.

Pulling the political and social together, the New Right stepped onto America's political scene during the 1970s and were able to make significant gains in a relatively short period of time. Episodes such as the textbook controversy showed the leaders of the New Right that a new conservative message needed to be created to fit a growing constituency. The New Right dispatched groups associated with it, like the Heritage Foundation, to places such as Kanawha County to help the protestors and to gain support for their overall political goals.

All of this action took place during the textbook controversy. As parents protested the inclusion of textbooks that they felt corrupted their children, they were voicing the concerns of millions of others throughout the nation. The content of their complaints points toward a larger dissatisfaction with the way the country is heading. Their rhetoric reflected lessons learned from the previous decade and provided a basis for future conservative political movements. 


\section{Endnotes}

\section{Introduction}

1.Quoted from Jerome L. Himmelstein, To The Right: The Transformation of American Conservatism (Berkeley: University of California Press, 1990), 85.

\section{Chapter 1}

1.Catherine Ann Candor, “A History of the Kanawha County Textbook Controversy, April 19741975" (Ph.D. diss., Virginia Polytechnic Institute and State University, 1976), 26.

2.National Education Association, Teacher Rights Division, Kanawha County, West Virginia: A Textbook Study in Cultural Conflict (Washington, DC: National Education Association, February 1975), 37.

3.Candor, 33-39.

4.West Virginia Board of Education, "Resolution: The Selection of Textbooks and Other Instructional Materials: Inter-Ethnic in Context, Concept, and Illustration.” Minutes of Meeting. (12 April 1974), 2.

5.James Moffett, Storm in the Mountains: A Case Study of Censorship, Conflict, and Consciousness (Carbondale: Southern Illinois UP, 1988), 5.

6.Paul Cowan, “A Fight Over America’s Future,” Village Voice, 9 December 1974, 20.

7.The Law stated, "The county board of education shall, upon recommendation of the country superintendent with the aid of a committee of teachers not to exceed five members...select from the state multiple list one or more book(s) or series of books from each subject and grade to be used as exclusive basal textbooks in the county for a period of five years.” (Candor, 40)

8.Ibid., 43.

9.Carol Mason, “Textual Reproduction of Ethnicity in the Kanawha Valley: The 1974 Textbook Controversy Revisited," Rockefeller Foundation and the Center for the Study of Ethnicity and Gender in Appalachia (Huntington: Marshall University, 2003), 51.

10.Lynn Withrow, "Voters to Elect Two Tuesday to School Board," Charleston Daily-Mail 8 May 1974. 
11.Lynn Withrow, “At the Big Confrontation: Who Makes the Decision,” Charleston Daily-Mail 21 May 1974.

12.Candor, 52-54.

13.Candor, 61.

14.“Text Foes to Explain Stand,” Charleston Sunday Gazette-Mail 28 July 1974.

15.Lynn Withrow, “Parents Group Planning Boycott, Book Campaigns,” Charleston Daily-Mail 3 August 1974.

16.Lynn Withrow, “Attendance Situation Vague on Textbook Boycott Threat,” Charleston Daily-Mail, 3 September 1974.

17.Ibid.

18.Lynn Withrow, “Miners Go Out in Supporting Books’ Boycott,” Charleston Daily-Mail, 4 September 1974.

19.Kay Michael, “2 Book Foes Deny Fueling School Boycott,” Charleston Gazette 6 September 1974.

20.“Kay Michael, “Minister Works Newer 'Flock,”” Charleston Gazette, 7 September 1974.

21.Candor, 109.

22.Kay Michael, “Text Protesters Reject Board’s Review Offer,” Charleston Gazette, 12 September 1974, 1.

23.Bob Adams and Richard Hass, "Melton Doubts His Policy Can Contain School Crisis,” Charleston Daily-Mail, 12 September 1974, 1 \& 4.

24. “Moore, Melton Sniping Catches Public In Middle,” Charleston Daily Mail, 13 September 1974, 1.

25.Barbara Randall, “Letter to Donna Knapp,” 17 September 1974.

26.Bob Adams and Richard Hass, "Melton Doubts His Policy Can Contain School Crisis,” 4. “'It's Over,' Says Protest Leader. Horan Claiming 'Fair Deal,'” Charleston Daily-Mail, 14 September, 1.

27.Candor, 122, 131-135,137-138,143,145, and 152.

28.Candor, 157-160. 
29.Quoted in Candor, 165.

30.Shirley A. Smith, FGTS—A Visit and Impressions (Charleston: Kanawha County Public Library, May 23, 1975), 2.

31.Ibid., 1.

\section{Chapter 2}

\section{Moffett, 7-8.}

2.John Egerton, “the Battle of the Books,” Progressive, June 1975, 13.

3.Russell W. Gibbons, “Textbooks In The Hollows,” Commonweal, 6 December 1974, 232.

4.Cowan, 21.

5.Calvin Trillin, “U.S. Journal: Kanawha County, West Virginia,” New Yorker, 30 September 1974, 123.

6.Curtis Seltzer, "West Virginia Book War: A Confusion of Goals,” The Nation, 2 November 1974, 435.

7.Scott Stanley, Jr., “Letter from the Editor,” American Opinion XVII, no. 10 (November 1974).

8.George W. Shannon, “Pro-Integration Textbooks Opposed,” The Citizen, February 1975, 31.

9.Ann L. Page and Donald A. Clelland, “The Kanawha County Textbook Controversy: A Study of the Politics of Life Style Concern,” Social Forces 57, no. 1 (September 1978): 267.

10.Ibid., 279.

11.Dwight Billings and Robert Goldman, “Comment on 'The Kanawha County Textbook Controversy,”, Social Forces 57, no. 4 (June 1979), 1393-1394.

12.Ibid., 1395.

13.Dwight B. Billings and Robert Goldman, "Religion and Class Consciousness in the Kanawha County School Textbook Controversy,” in Appalachia and America, ed. Allen Batteau (Lexington: University of Kentucky Press, 1983), 80-81. Billings and Goldman, "Comment on 'The Kanawha County Textbook Controversy,'” 1396.

14.John Gaventa, Power and Powerlessness: Quiescence and Rebellion in an Appalachian Valley (Urbana: University of Illinois Press, 1980), 255-256. 
15.Ibid., 256.

16.Gaventa outlines three dimensions of power. The first dimension simply involves competing interest groups, with the power group's actions not necessarily affecting the powerless's actions: a Pluralist society. The second dimension involves those in power gaining and controlling access to that power and the establishment of a mobilization of bias to insulate their power. Finally, the third dimension is the process of the powerless accepting their condition, thus creating this sense of powerlessness.

17.Barry Bluestone and co. investigate America's low-paid workforce and the determinants of low-wage employment in their work Low Wages and the Working Poor (Ann Arbor: University of Michigan-Wayne State University, 1973).

18. With God On Their Side - Episode Two: The Zeal of Thy Home [Video Recording]. Directed by Calvin Skaggs (Lumiere Productions, 1996).

19.Mason, “Textual Reproduction of Ethnicity in the Kanawha Valley: The 1974 Textbook Controversy Revisited,” 1.

20.Carol Mason, “An American Conflict: Representing the 1974 Kanawha County Textbook Controversy,” Appalachian Journal 32, no. 3 (Spring 2005), 366.

\section{Chapter 3}

1.Billings and Goldman, "Religion and Class Consciousness in the Kanawha County School Textbook Controversy”

2.F. David Wilkin, “The Kanawha County, West Virginia, Textbook Issue: Social Policy in Dispute,” Term Paper dated January 6, 1975, 31.

3.“But Why the Children,” Editorial, Charleston Daily-Mail, 2 September, 1974.

4.Harry C. Boyte, The Backyard Revolution: Understanding the New Citizen Movement (Philadelphia: Temple University Press, 1980), 24-5.

5.Sara M. Evans and Harry C. Boyte, Free Spaces: The Sources of Democratic Change In America (New York: Harper and Row Publishers, 1986), 17-18.

6.Jim Lewis, “Some Ugly Demons Now Roam Hollows,” Charleston Gazette, 6 November 1974. Lewis is still out there speaking about the textbook controversy. After moving away from Charleston for a couple of decades, he returned early in the Twenty-First century and sat on a panel that discussed the textbook controversy thirty years later. He is reportedly working on a book about the controversy.

7.Mount Calvary Missionary Baptist, “An Open Letter (Paid Advertisement),” Charleston Daily- 
Mail 28 September 1974.

8.Ralph W. Workman, "Concern! Of the Members of the Congreation of Rock Branch Church of God Mission (Paid Advertisement),” Charleston Gazette, 18 September 1974.

9.Lewis Harrah, “Notice (Paid Advertisement),” Charleston Gazette, 11 September 1974.

10.Speakers had to apply earlier in the week for a chance to speak at the meeting.

11.Board member at the time, Russell Isaacs, tells of how he had to have bodyguards due to threatening phone calls he was receiving on a regular basis. He also relates how he bought a shotgun for his protection. He was under twenty-four hour police protection and federal marshals made sure his children got to and from school safely, showing that tension was high for the board members as well.

12.Louella Brown, “Letter to the Editor,” Charleston Gazette, 22 October 1974.

13.Arnold Bailey, “Letter to the Editor,” Charleston Gazette, 18 November 1974.

14.A Parent, “Letter to the Editor,” Charleston Daily-Mail, 25 September 1974.

15.Billings and Goldman, “Comment on 'The Kanawha County Textbook Controversy,” 1394.

16.A quote from Ross K. Baker and Bart Barnes who wrote a feature article on the textbook controversy in the Washington Post, 17 November 1974. Taken from Curtis Seltzer, "The Media vs. Appalachia: A Case Study,” Mountain Review (May 1976) vol. 3, no. 2, 10.

17. Robert Fisher, Let the People Decide: Neighborhood Organizing in America, (Woodbridge: Twayne Publishers, 1984), 159.

18.Richard Jay Jenkins, Rebellion in the United Mine Workers: The Miners for Democracy, 1970 - 1972. (Ph.D. dissertation: Indiana University, 1974), 12.

19.Bennett M. Judkins, “The People’s Respirator: Coalition Building and the Black Lung Association,” in Fighting Back in Appalachia: Traditions of Resistence and Change, Stephen L. Fisher, ed. (Philadelphia: Temple University, 1993), 226-227.

20.Ibid.

21.Curtis Seltzer, Fire in the Mountains: Miners and Managers in the American Coal Industry (Lexington: University of Kentucky Press, 1985), 98.

22.Mary Beth Bingman, “Stopping the Bulldozers: What Difference Did it Make?,” in Fighting Back in Appalachia: Traditions of Resistence and Change, ed. Stephen L. Fisher (Philadelphia: Temple University Press, 1993), 28. 
23.Ibid, 28-29.

24.Seltzer, 97.

25.Frances Fox Piven and Richard A. Cloward, Poor People's Movements: Why They Succeed, How They Fail (New York: Vintage Books, 1979).

26.Ibid, 33.

27.Chip Berlet, Right-Wing Populism in America: Too Close for Comfort (New York: Guilford Press, 2000), 7.

28.Interview with Russell L. Isaacs.

29.“Moore Urges Arbitration On Textbooks,” Charleston Daily Mail 10 September 1974.

30.Interview with Governor Arch A. Moore, Jr.

\section{Chapter 4}

1.Jerome L. Himmelstein, To the Right: The Transformation of American Conservatism (Berkeley: University of California Press, 1990), 6.

2.Oscar Lewis, “The Culture of Poverty,” On Understanding Poverty: Perspectives from the Social Sciences, ed. Daniel P. Moynihan (New York: Basic Books, Inc. Publishers, 1968), 188189.

3.National Education Association, 41.

4.F. David Wilkin, “The Kanawha County, West Virginia, Textbook Issue: Social Policy in Dispute” (Term Paper dated January 6, 1975), 30.

5."Rex Smith Cites Need For Long-Range Plan,” Appalachian Advance 1, no. 1 (October 1966), 25.

6.Ronald L. Lewis and Dwight B. Billings, “Appalachian Culture and Economic Development: A Retrospective View on the Theory and Literature,” Journal of Appalachian Studies 3, no. 1 (1997), 7.

7.Harry K. Schwarzweller and James S. Brown, "Education as a Cultural Bridge between Appalachian Kentucky and the Great Society,” Change in Rural Appalachia: Implications for Action Programs, ed. John D. Photidas and Harry K. Schwarzweller (Philadelphia: University of Pennsylvania Press, 1970), 136.

8.“Rex Smith Cites Need for Long-Range Plan,” 32. 
9.James Branscome, “Educating Appalachia’s Poor,” Appalachia: Social Context Past and Present ed. Bruce Ergood and Bruce E. Kuhre (Dubuque: Kendall/Hunt Publishing Co., 1976), 222.

10."Head Start: Still the Educational Program Favorite,” Appalachian Advance 1, no. 1 (October 1966), 9-11.

11.Fred E. Smith, “Letter to the Editor,” Charleston Gazette, 19 September 1974.

12.Richard D. Mosier, Making the American Mind: Social and Moral Ideas in the McGuffey Readers (New York: King Crown Press, 1947), 55.

13.Bruce Crawford, “McGuffey: Lessons in Goodness,” West Virginia History 4, no. 1 (October 1942), 37.

14.Dan T. Carter, The Politics of Rage: George Wallace, the Origins of the New Conservatism, and the Transformation of American Politics (New York: Simon and Schuster, 1995), 11.

15.Ibid., 12.

16.Ibid.

17.“ATTENTION PATRIOTS! (Advertisement)” Charleston Gazette, 19 July 1975.

18.Wilkin, 33.

19.V. Hansford, “Letter to the Editor,” Charleston Gazette, 25 September 1974.

20.Charles Hamilton, “Letter to the Editor,” Charleston Gazette, 3 December 1974. Randall Balmar examines the Evangelical subculture in his Mine Eyes Have Seen the Glory: A Journey into the Evangelical Subculture (New York: Oxford UP, 1989), where he says, "Evangelicals have been eager in recent years to recast American history according to the shibboleths of the political right.... This revisionism has also given rise to rather comic attempts to transform people like Thomas Jefferson, Thomas Paine, James Madison, and Abraham Lincoln into something like fundamentalists.” (122)

21.Sam Sayre, “Letter to the Editor,” Charleston Gazette, 7 September 1974.

22.Linda K. Shinault, “Letter to the Editor,” Charleston Daily-Mail, 21 September 1974.

23.Rebecca E. Klatch, Women of the New Right (Philadelphia: Temple University Press, 1987.), 22-25.

24.Ibid. 
25.Moffett, 63.

26.Maisie Neil, “Letter to the Editor,” Charleston Gazette, 19 September 1974.

27.Harry Ellis, “Letter to the Editor,” Charleston Gazette, 19 October 1974.

28.Magdalene Paxton, “Letter to the Editor,” Charleston Gazette, 23 October 1974.

29.Berta Hanshaw, “Letter to the Editor,” Charleston Daily-Mail, 9 October 1974.

30.Betty Mooney, “Letter to the Editor,” Charleston Daily-Mail, 23 December 1974.

31.Klatch, 55-56. Since the government is God-ordained, a religious world view that stresses obedience to authority and assumes that such obedience will provide a context for individuals to pursue the right relationships with God legitimates existing social hierarchies. So order itself implies hierarchy. In free enterprise countries, hierarchies of power and wealth are intertwined, “thus, what religion legitimates, what it affirms as 'goodness' in citizens, is respect for free market dealings through which the industrious can acquire means.”Communism doesn't allow for this respect of the free market, so it gets labeled as evil. (David C. Leege and Lyman A. Kellstedt, "Religious Worldviews and Political Philosophies: Capturing Theory in the Grand Manner through Empirical Date,” Rediscovering the Religious Factor in American Politics, ed. Leege and Kellstedt (Armonk, NY:M.E. Sharpe, 1993), 219).

32.Ibid., 59.

33.Mrs. Richard Wills, “Letter to the Editor,” Charleston Daily-Mail, 2 September 1974.

34.Bertha I.O. Weese, “Letter to the Editor,” Charleston Gazette, 3 October 1974.

35.Mrs. Carol Sue Graley, “Letter to the Editor,” Charleston Gazette, 1 March 1975.

36.Linda J. Hoal, “Letter to the Editor,” Charleston Gazette, 17 September 1974.

37.W.R. Staats, “Letter to the Editor,” Charleston Gazette, 27 July 1974.

38.Carrena Roberts, “Letter to the Editor,” Charleston Gazette, 25 September 1974.

39.Moffett, 96.

40.Michael Omi and Howard Winant, Racial Formation in the United States: From the 1960s to the 1990s, $2^{\text {nd }}$ ed. (New York: Routledge, 1994), 2, 116-117.

41.Ibid., 124.

42.West Virginia Human Rights Commission, Ninth Annual Report for the Fiscal Year of 1969- 
1970 (Charleston: West Virginia Human Rights Commission, 1970), 6.

43.Ibid., 41.

44.Lynn Withrow, “Proving Segregation Still Difficult Job,” Charleston Gazette, 25 June 1974. Lynn Withrow, "Subtle Discrimination Present in Charleston,” Charleston Gazette, 24 June 1974.

45.National Education Association, 44.

46. '74 Graduate of DuPont High, "Letter to the Editor,” Charleston Daily-Mail, 31 October 1974.

47.Moffett, 78.

48.Elizabeth Damewood claims that the protestors' racist leanings were due to their lack of exposure to African-Americans. While this might have a something to do with the attitudes of some of the protestors, it is certainly not a conclusive argument. In July 1975, 10.3\% of Charleston’s 67,348 residents were black, roughly 6,528. Between 1960 and 1970, Charleston witnessed a $10.6 \%$ decline in its black population. Statewide the total African-American population dropped from 5.7\% in 1950 to 3.6\% in 1975. This followed the trend of population for all of Charleston. Between 1970 and 1975, 5.8\% of all Charlestonians had disappeared from the census.(Elizabeth Rhodes Damewood, “Kanawha County’s 'Great Textbook Controversy': Regional Heritage, National History, and Public Education, 1974-1975,” Paper Submitted to the Kelley Honors Seminar [Davidson: Davidson College, May 1990], 13).

49.Damewood, 35. Dorothy Z. Seymour, “Black Children, Black Speech,” Commonweal, 19 November 1971, 175.

50.Shirley A. Smith, Report from WV - March 15, 1975 (Charleston: Kanawha County Public Library, Extension Department, 1975), 1.

51.Miss Raynett Pauley, “Letter to the Editor,” Charleston Daily-Mail, 29 January 1975.

52.John F. Kessline, “Letter to the Editor,” Charleston Daily-Mail, 11 February 1975.

53.Moffett, 97. Babi Yar is a site of a mass murder Ukranian Jews, outside of Kiev, by German paramilitary execution squads. Over thirty-three thousands Jews were slaughtered over a twoday period at Babi Yar. The massacre inspired a poem written by Russian poet Yevgeny Yevtushenko, which was later set to music by composer Dmitri Shostakovich in his Symphony No. 13.

54.An Illiterate Hillbilly, “Letter to the Editor,” Charleston Daily-Mail, 16 October 1974.

55.Evangeline H. Tucci, “Letter to the Editor,” Charleston Gazette, 25 October 1974. 
56.Robert Boggs, “Letter to the Editor,” Charleston Gazette, 8 October 1974.

57.Berlet, 209.

58.Klatch, 61. With God On Their Side - Episode Two: The Zeal of Thy Home [Video Recording].

59.Sheldon Ackley, "Secular Humanism and the Schools," Religious Humanism 20, no. 3 (Summer 1986), 132.

60.Darrell Dobbs, "Kanawha County Board of Education Special Meeting, 16 Speakers: Re: Textbooks [Audio Recording],” Tape One, 27 June 1974.

61.Klatch, 61-64.

62.Leonard Bruce Cooper, "Letter to the Editor,” Charleston Gazette, 19 February 1975.

63.Paul J. Kaufman, “Alice’s Wonderland; Or, School Books Are for Banning,” Appalachian Journal 2, no. 3 (Spring 1975), 162.

64.Berlet, 208.

65.V.L. McDaniel, “Letter to the Editor,” Charleston Gazette, 28 June 1974.

66.James E. Davis, “Recent Censorship Fires: Flareups or Holocaust? Time: 1970-1976.

Temperature: Fahrenheit 451," Journal of Research and Development in Education 9, no. 3 (1976), 28-30.

67.Moffett, 80.

68.Jean Kinder, “Letter to the Editor,” Charleston Gazette, 28 September 1974.

69.Moffett, 80 .

70.Ferrell Kennedy, “Letter to the Editor,” Charleston Gazette, 18 November 1974.

\section{Chapter 5}

1.Crawford, 78.

2. Ronald Reagan, “Unforgettable John Wayne,” Readers Digest 115, no. 690 (October 1979), 117.

3. Ibid., 118. 
4. Ibid., 119.

5. With God On Their Side [video recording].

6. Omi and Winant, 122.

7. Seymour Martin Lipset and Earl Raab, The Politics of Unreason: Right-Wing Extremists in America, 1790-1977 (Chicago: University of Chicago Press, 1978), 24. Lipset and Raab go into further detail into monism, saying it "amounts to the closing down of the democratic market place, whether by a massive majority or by a preemptive minority. The monistic impulse, however, in the context of the American political metaphor, must be legitimated by rendering illegitimate those who are to be ruled out of the market place. Enter the imputation of deliberate evil, rather than lack of wisdom; enter the elements of absolutism, moralism, and conspiracy, and enter, of course, the conspiracy target.” (428)

8. Richard Hofstadter, “The Paranoid Style in American Politics,” The Paranoid Style in American Politics and Other Essays (New York: Alfred A. Knopf, 1965), 4.

9. In the "Forum" section of the American Historical Review, Alan Brinkley and Leo P. Ribuffo debated the historiography of American conservatism. Brinkley was surprised by the lack historical scholarship on the topic, especially after recent conservative successes, which took liberal scholars by surprise. Ribuffo countered by saying that a great deal of research exists, and that these successes result directly from centuries of development. Leo P. Ribuffo, "Why Is There So Much Conservatism in the United States and Why Do So Few Historians Know Anything About It?” American Historical Review 99, no. 2 (April 1994), 430-440. Alan Brinkley, “The Problem of American Conservatism,” American Historical Review 99, no. 2 (April 1994), 411-412.

10. Brinkley, 423.

11. Lisa McGirr, Suburban Warriors: The Origins of the New American Right (Princeton: Princeton UP, 2001), 8.

12. Ibid., 113.

13. Ibid., 163.

14. Richard Viguerie, “Ends and Means,” The New Right Papers. Ed. By Robert W. Whitaker (New York: St. Martins Press, 1982), 30.

15.He even liked to brag about winning every county but one in Michigan in 1972, before being shot. Joe Klein, “The Ministry of George Wallace,” Rolling Stone, 24 October 1974, 38.

16. Omi and Winant, 124. 
17. Crawford, 5.

18. Omi and Winant, 117 \& 123.

19. Ibid., 33.

20. There was a strong movement within the New Right to break away from the Republican Party. Conservative Caucus founder Howard Phillips did split with the Republican Party in 1974 and devoted his efforts in trying to get conservatives elected to national office. Phillips said, "The Republican Party was a house divided against itself, and could only offer the lowest common denominator in politics. Our hope for victory was through the strategy of a united plurality, rather than one of a divided majority. And that in order to do that, we had to start somewhere, building a Party committed to those biblical, constitutional principles which by God's grace could at some point bring a government to office.” Phillips founded the U.S. Taxpayers Party in 1992. From Mark Dankof, “The Last Honorable Politician?” www.conservativeusa.org/worldnet.htm 11 November 2005.

21. John S. Saloma, III, Ominous Politics: The New Conservative Labyrinth (New York: Hill and Wang, 1984), 95.

22. Dankof.

23. This loosening did appear during the textbook controversy, as some protestors began exposing a break from traditional party loyalties: "I know the only way to get rid evil is to get rid of evil people.... We had better vote for the man and not the party from now on, for this is our only way of keeping evil people where they belong out of authority." (Bill Ford, "Letter to the Editor,” Charleston Daily-Mail 8 November 1974.) Sentiment like this helped propel the New Right sympathizers into office around the country throughout the rest of the seventies on up to today.

24. Mary C. Brennan, "Winning the War/Losing the Battle: The Goldwater Presidential Campaign and Its Effects on the Evolution of Modern Conservatism," in The Conservative Sixties. Eds. David Farber and Jeff Roche (New York: Peter Lang Publishing, Inc., 2003), 71.

25. Viguerie, 30.

26. Crawford, $127 \& 245$.

27. Elaine B. Sharp, “Introduction,” in Culture Wars and Local Politics. Ed. By Elaine B. Sharp (Lawrence: UP of Kansas, 1999), 3.

28. James Davison Hunter, Culture Wars: The Struggle to Define America (New York: Basic Books, 1991), 42.

29. Protestors provided many examples of this phenomenon: "I wonder how we have gotten 
carried away from our godly conscience not to remember all men in our trials, tribulations, and grievances even with government.... I have wondered are there some politicians in the upper Kanawha Valley that really feel honest sincere Christians will let them lead them against elected authority, disobey the law of government authority, give up their peaceful honest lives to seek after corrupt politicians. God only knows their true sins. I pray not.... God evidently doesn't think much of law violators, rioters, revoluters [sic], trouble makers, and authority violators and truce breakers.” P. Lanham, “Letter to the Editor,” Charleston Daily-Mail, 17 December 1974.

30. Hunter, 58-9.

31. Paul Gottfried, The Conservative Movement (New York: Twayne Publishers, 1993), 108 \& 110.

32. Saloma, III, 14-16.

33.www.heritage.org 11/21/05.

34. Candor, 127.

35.Moffett, 41.

36.Candor, 127. James McKenna interview from With God On Our Side: Episode Two - The Zeal of Thy House [television documentary] (Lumiere Productions, 1996).

37.Robert J. Hoy, “Lid on a Boiling Point,” in The New Right Papers.

38.Robert A. Whitaker, Whitaker's Law on Political Financing, January 15, 2000, $<$ http://www.whitakeronline.org/011500.htm>, [April 11, 2005].

39.Hoy, 90-91.

40. William Martin, With God On Our Side: The Rise of the Religious Right in America (New York: Broadway Books, 1996), 135.

41. Ibid.

42.Gillian Peele, Revival and Reaction: The Right in Contemporary America (Oxford: Clarendon Press, 1984), 10.

43.Ibid. Himmelstein, 126.

44. The New Christian Right is still in existence and still is very powerful. Their influence can be seen in recent controversies over abortion, the case of Terry Schiavo, and Supreme Court nominees. They are a large and powerful voting bloc that politicians are constantly scrambling over each other to gain their support. The can be accredited with single-handedly stopping the 
Supreme Court nomination of Harriet Miers before it ever really got started. Some of the old leaders like Jerry Falwell and Pat Robertson are still making news. Recently, Robertson called on the assassination of Venezuelan president Hugo Chavez. So the name "New Christian Right" might not be appropriate anymore, seeing they have been around since the 1970s.

45.Clyde Wilcox’s God's Warriors (Baltimore: John Hopkins UP, 1992) gives a thorough analysis of Pat Robertson's presidential campaign.

46.Glenn H. Utter and James L True, Conservative Christians and Political Participation (Santa Barbara: ABC-CLIO, Inc., 2004), 28.

47.Social gospel is particularly associated with the late nineteenth and early twentieth century movement led by Washington Gadden and Walter Rauschenbusch to try and put an end to some of the problems associated with industrialization like child labor and conditions in the ghettoes.

48.Utter and True, 28.

49.Moffett, 41.

50. Martin, 97.

51.Martin E. Marty, Religion and Republic: The American Circumstance (Boston: Beacon Press, 1987, 25.

52.Amanda, Porterfield, The Transformation of American Religion: The Story of a LateTwentieth Century Awakening (New York: Oxford University Press, 2001), 96.

53.Echo E. Fields, "Understanding Activist Fundamentalism: Capitalist Crisis and the 'Colonization of the Lifeworld,”' Sociological Analysis 52, no. 2 (1991): 183-185.

54.Marty, Religion and Republic, 291.

55.Ibid., 299-300.

56.Michael, Lienesch, "Right-Wing Religion: Christian Conservatism as a Political Movement." Political Science Quarterly 97, no. 3 (Fall 1982): 410. Donald Heinz, "The Struggle to Define America.” In The New Christian Right: Mobilization and Legitimation. eds. Robert C. Liebman and Robert Wuthnow, (New York: Aldine Publishing Co., 1983),142 .

57.Lienesch, 414. Wilcox, 12.

58.Clayton L. McNearney, “The Kanawha County Textbook Controversy,” Religious Education LXX, no. 5 (September-October, 1975), 526.

59.Edwin D. Sheen, “Letter to the Editor,” Charleston Gazette, 22 June 1974. 
60.V. L. McDaniel, “Letter to the Editor,” Charleston Gazette, 28 June 1974.

61.Richard Wilson, “Letter to the Editor,” Charleston Daily-Mail, 19 November 1974.

62.B. Kackie, “Letter to the Editor,” Charleston Daily-Mail, 26 September 1974.

63.Candor, 48.

64. Weller, 126.

65.Thomas R. Ford, "Status, Residence, and Fundamentalism Religious Beliefs in the Southern Appalachian,” Social Forces 39, no. 1 (1960), 41.

66.Ibid., 42-43.

67.John D. Photiadis, “A Theoretical Supplement,” Religion in Appalachia: Theological, Social, and Psychological Dimensions and Correlates, ed. John D. Photiadis (Morgantown: West Virginia University, 1978), 14.

68.Bill J. Leonard, “Introduction,” Christianity in Appalachia: Profiles in Regional Pluralism, ed. Bill J. Leonard (Knoxville: University of Tennessee Press, 1999), xix.

69.Ferris L. Jones, “Textbooks Are Criminal Injury To Personality,” Coal Valley News, 10 October 1974.

70.Loyal Jones, “Appalachian Values,” in Appalachia: Social Context Past and Present, ed. Bruce Ergood and Bruce E. Kuhre, $3^{\text {rd }}$ ed. (Dubuque: Kendall/Hunt Publishing Co., 1991), 170.

71.Ibid.

72.Deborah Vansau McCauley, Appalachian Mountain Religion: A History (Urbana: University of Illinois Press, 1995), 52.

73.Loyal Jones, Faith and Meaning in the Southern Uplands (Urbana: University of Illinois Press, 1999), 204-205. Charles H. Lippy, “Popular Religiosity in Central Appalachia.” In Christianity in Appalachia: Profiles in Regional Pluralism. ed. Bill J. Leonard. (Knoxville: University of Tennessee Press, 1999), 41-42, 47.

74.Jones, “Appalachian Values,” 171.

75.Bill Ford, “Letter to the Editor,” Charleston Daily-Mail, 18 December 1974.

76.Jones, “Appalachian Values,” 172. Jones, Faith and Meaning, 204.

77.Mrs. Franklin W. Pauley, “Letter to the Editor,” Charleston Daily-Mail, 3 September 1974. 
78.Robert Boggs, “Letter to the Editor,” Charleston Gazette, 8 October 1974.

79.S.E. Barton, “Letter the Editor,” Charleston Daily-Mail, 30 October 1974.

80.Carl Williamson, “Letter to the Editor,” 7 October 1974.

81.Mrs. Sue Hunt, “Letter to the Editor,” Charleston Gazette, 28 September 1974.

82.Thomas R. Ford, "Status, Residence, and Fundamentalism Religious Beliefs in the Southern Appalachian,” Social Forces 39, no. 1 (1960), 43.

83.Bill J. Leonard,ed. Christianity in Appalachia: Profiles in Regional Pluralism (Knoxville: University of Tennessee Press, 1999), xx. Thomas R. Ford, “Status, Residence, and Fundamentalism Religious Beliefs in the Southern Appalachian,” Social Forces 39, no. 1 (1960), 43.

84.Ruth Orndorff, “Letter to the Editor,” Charleston Daily-Mail, 28 January 1975.

85.Mrs. Pamela Conant, “Letter to the Editor,” Charleston Daily-Mail, 1 November 1974.

86.Martin E. Marty, "Religion in America since Mid-century,” Daedulus 111, no. 1 (Winter 1982), 160.

87.Frances Buzzard, “Letter to the Editor,” Charleston Gazette, 17 September 1974.

88.Mrs. Elma Armstrong, “Letter to the Editor,” Charleston Gazette, 26 June 1975.

89.Jimmy Quinn, “Letter to the Editor,” Charleston Gazette, 9 January 1975.

90.Rev. John R. Whittington, “Letter to the Editor,” Charleston Daily-Mail, 1 January 1975.

91.A.W. White, “Letter to the Editor,” Charleston Daily-Mail, 30 September 1974.

92.Harvey M. Holdren, “Letter to the Editor,” Charleston Gazette, 4 December 1974.

93. In the Old Testament, Satan is an adversary, the opposer of Good. While, in the New Testament, the devil seeks to expose and vilify the faithful. So there is a distinction, but both seem to be working in today's society.

94.Jones, 76. 


\section{Bibliography}

\section{Primary Sources}

Audio Recording of Debate between Alice Moore and Lee Platt. [cassette tape]. Date unknown.

Isaacs, Russell. Interview by author. Charleston, West Virginia, 6 July 2005.

Kanawha County Board of Education. Special Meeting. 16 Speakers. Re: Textbooks [cassette tapes]. 27 June 1974.

Marsh, Don. “Letter to Shirley A. Smith.” February 25, 1975.

Minutes of Meeting. West Virginia Board of Education. 1974.

Moore, Arch A., Jr. Interview by author. Moundsville, West Virgiania, 20 October 2005.

National Education Association, Teacher Rights Division. Kanawha County, West Virginia: A Textbook Study in Cultural Conflict. Washington: National Education Association, February 1975.

Smith, Shirley A. FGTS - A Visit and Impression [Report]. Charleston: Kanawha County Public Library, May 23, 1975.

Smith, Shirley A. Report from West Virginia [Report]. Charleston: Kanawha County Public Library, February 25, 1975.

West Virginia Human Rights Commission. Eighth Annual Report. Fiscal Year 1968-1969. Charleston: West Virginia Human Rights Commission, 1969.

West Virginia Human Rights Commission. Ninth Annual Report. Fiscal Year 1969-1970. Charleston: West Virginia Human Rights Commission, 1970.

West Virginia Human Rights Commission. Combined Annual Report for 1970-1971 and 19711972. Charleston: West Virginia Human Rights Commission, 1972.

\section{Newspapers}

Charleston Daily-Mail

Charleston Gazette

Chicago Tribune 


Coal Valley News
Kanawha Valley Leader
Miami Herald
National Observer
New York Times
Wall Street Journal
Washington Post

\section{Secondary Sources}

“About Howard Phillips.” ConservativeUSA.org. [on-line]. <www.conservativeusa.org/hpbo.htm.> [21 November 2005].

“About The Conservative Caucus.” ConservativeUSA.org. [on-line].

<www.conservativeusa.org/whoweare.html.> [21 November 2005].

“About the Heritage Foundation.” Heritage Foundation. [on-line]. <www.heritage.org.> [21 November 2005].

“Head Start: Still the Educational Program Favorite.” Appalachian Advance 1, no. 1 (October 1966): 9-11.

“Operation Pebble.” Appalachian Advance 1, no. 1 (October 1966): 26-28.

Ackley, Sheldon. “Secular Humanism and the Schools.” Religious Humanism 20, no. 3 (Summer 1986): 130-136.

Andrew III, John A. The Other Side of the Sixties: Young Americans for Freedom and the Rise of Conservative Politics. New Brunswick: Rutgers University Press, 1997.

Anglin, Mary K. "Lessons from Appalachia in the $20^{\text {th }}$ Century: Poverty, Power, and the 'Grassroots.'” American Anthropologist 104, no. 2 (June 2002): 565-582.

Armbrister, Trevor. “The Coal-Black Shame of the UMW.” Readers’ Digest, October 1970: 135-140.

Balmar, Randall. Mine Eyes Have Seen the Glory: A Journey into the Evangelical Subculture in America. New York: Oxford University Press, 1989.

Bellah, Robert N., Richard Madsen, William M. Sullivan, Ann Swidler, and Steven M. Tipton. Habits of the Heart: Individualism and Commitment in American Life. Berkeley: University of California Press, 1985. 
Berlet, Chip. “Anatomy of the Right.” The Progressive 59, no. 12 (December 1995).

Berlet, Chip. Right-Wing Populism in America: Too Close for Comfort. New York: Guilford Press, 2000.

Berlet, Chip. “The Great Right Snark Hunt.” The Humanist, September/October 1992, 14-17.

Billings, Dwight. "Culture and Poverty in Appalachia: A Theoretical Discussion and Empirical Analysis.” Social Forces 53, no. 2 (December 1974): 315-323.

Billings, Dwight and Robert Goldman. "Comment on 'The Kanawha County Textbook Controversy.” Social Forces 57, no. 4 (June 1979): 1393-1398.

Billings Dwight B. and Robert Goldman. "Religion and Class Consciousness in the Kanawha County School Textbook Controversy.” In Appalachia and America, ed. Allan Batteau. Lexington: University of Kentucky Press, 1983.

Billings, Dwight B. and Shaunna L. Scott. "Religion and Political Legitimation.” Annual Review of Sociology 20 (1994): 173-201.

Bingman, Mary Beth. “Stopping the Bulldozers: What Difference Did it Make?” In Fighting Back in Appalachia: Traditions of Resistence and Change. ed. Stephen L. Fisher. Philadelphia: Temple University Press, 1993.

Bjerre-Poulsen, Niels. Right Face: Organizing the American Conservative Movement, 19451965. Copenhagen: Museum Tusculanum Press, 2002.

Bluestone, Barry, William M. Murphy, and Mary Stevenson. Low Wages and the Working Poor. Ann Arbor: Institute of Labor and Industrial Relations, 1973.

Boyte, Harry C. The Backyard Revolution: Understanding the New Citizen Movement. Philadelphia: Temple University Press, 1980.

Branscome, James. “Educating Appalachia’s Poor.” In Appalachia: Social Context Past and Present, eds. Bruce Ergood and Bruce E. Kuhre, 222-225. Dubuque: Kendall/Hunt Publishing Co., 1976.

Brennen, Mary C. "Winning the War/Losing the Battle: The Goldwater Presidential Campaign and its Effects on the Evolution of Modern Conservatism.” In The Conservative Sixties. eds. David Farber and Jeff Roche. New York: Peter Lang Publishing, Inc., 2003.

Brinkley, Alan. “Response to the Comments of Leo Ribuffo and Susan Yohn.” American 
Historical Review 99, no. 2 (April 1994): 450-452.

Brinkley, Alan. “The Problem of American Conservatism.” American Historical Review 99, no. 2 (April 1994): 409-429.

Burger, Robert H. "The Kanawha County Textbook Controversy: A Study of Communication and Power.” Library Quarterly 48, no. 2 (1978): 143-162.

Candor, Catherine Ann. “A History of the Kanawha County Textbook Controversy, April 1974- 1975.” Ph.D. diss., Virginia Polytechnic Institute and State University, 1976.

Carper, James C. and William J. Weston. "Essay Review: Conservative Protestants in the New School Wars.” History of Education Quarterly 30, no. 1 (Spring 1990): 79-87.

Carter, Dan T. The Politics of Rage: George Wallace, the Origins of the New Conservatism, and the Transformation of American Politics. New York: Simon and Schuster, 1995.

Clelland, Donald A. and Ann L. Page. "Kanawha County Revisited: Reply to Billings and Goldman.” Social Forces 59, no. 1 (September 1980): 281-284.

Conley, Thelma R. "Scream Silently: One View of the Kanawha County Textbook Controversy.” Journal of Research and Development in Education 9, no. 3 (1976): 93101.

Cook, Samuel DuBois. “The New Conservatism Versus American Traditions.” American Behavioral Scientist 17, no. 2 (November/December 1973): 272-278.

Couto, Richard A. with Catherine S. Guthrie. Making Democracy Work Better: Mediating Structures, Social Capital, and the Democratic Prospect. Chapel Hill: The University of North Carolina Press, 1999.

Cowan, Paul. “A Fight Over America’s Future.” Village Voice, 9 December 1974: 1923.

Crawford, Alan. Thunder on the Right: The 'New Right' and the Politics of Resentment. New York: Pantheon Books, 1980.

Crawford, Bruce. “McGuffey: Lessons in Goodness.” West Virginia History 4, no. 1 (October 1942): 37-41.

Damewood, Elizabeth Rhodes. “Kanawha County’s 'Great Textbook Controversy’: Regional Heritage, National History, and Public Education - 1974-1975.” Paper Submitted to the 
Kelley Honors Seminar, Davidson College, May 1990.

Dankof, Mark. “The last honorable politician?” WorldNetDaily.com. 12 October 1998 [on-line]. $<$ www.conservativeusa.org/worldnet.htm> [21 November 2005].

Davis, James E. “Recent Censorship Fires: Flareups or Holocaust? Time: 1970-1976.

Temperature: Fahrenheit 451.” Journal of Research and Development in Education 9, no. 3 (1976): 22-32.

DeYoung, Alan J. "Constructing and Staffing the Cultural Bridge: The School as Change Agent in Rural Appalachia.” In Appalachia: Social Context Past and Present, $4^{\text {th }}$ edition, ed. Phillip J. Obermiller and Michael E. Maloney, 166-182. Dubuque: Kendall/Hunt Publishing Co., 2002.

Diamond, Sara. Roads to Dominion: Right-Wing Movements and Political Power in the United States. New York: The Guilford Press, 1995.

Diamond, Sara. Spiritual Warfare: The Politics of the Christian Right. Boston: South End Press, 1989.

Doyle, Barrie. “West Virginia Uproar: Contesting the Textbooks.” Christianity Today, 11 October 1974, 44-46.

Durr, Kenneth D. Behind the Backlash: White Working-Class Politics in Baltimore, 1940-1980. Chapel Hill: University of North Carolina Press, 2003.

Edwards, June Kirkhuff. “The Textbook Controversy: A Political Confrontation.” Christian Century, 13 November 1974, 1064-1066.

Egerton, John. “The Battle of the Books.” The Progressive, June 1975, 13-17.

Euchner, Charles C. Extraordinary Politics: How Protest and Dissent Are Changing American Democracy. Boulder: Westview Press, 1996.

Evans, Sara M. and Harry C. Boyte. Free Spaces: The Sources of Democratic Change in America. New York: Harper and Row, Publishers, 1986.

Falwell, Jerry and Ed Dobson, eds. The Fundamentalist Phenomenon: The Resurgence of Conservative Christianity. Garden City: Doubleday and Co., Inc., 1981.

Farber, David and Jeff Roche, eds. The Conservative Sixties. New York: Peter Lang Publishing, Inc., 2003. 
Feigert, Frank B. “Conservatism, Populism, and Social Change.” American Behavioral Scientist 17, no. 2 (November/December1973): 272-278.

Feldman, Glenn. “The Status Quo Society, the Rope of Religion, and the New Racism.” In Politics and Religion in the White South. ed. Glenn Feldman, 287-352. Lexington: University Press of Kentucky, 2005.

Fields, Echo E. "Understanding Activist Fundamentalism: Capitalist Crisis and the 'Colonization of the Lifeworld.” Sociological Analysis 52, no. 2 (1991): 175-190.

Fisher, Robert. Let the People Decide: Neighborhood Organizing in America. Boston: Twayne Publishers, 1984.

Fisher, Stephen L., ed. Fighting Back in Appalachia: Traditions of Resistence and Change. Philadelphia: Temple University Press, 1993.

Fisher, Stephen L. “The Grass Roots Speak Back.” In Back Talk from Appalachia: Confronting Stereotypes, eds. Dwight B. Billings, Gurney Norman, and Katherine Ledford, 203-214. Lexington: University of Kentucky Press, 1999.

Flamm, Michael W. "The Politics of 'Law and Order.'” In The Conservative Sixties. eds. David Farber and Jeff Roche.

Ford, Thomas R. "Status, Residence, and Fundamentalist Religious Beliefs in the Southern Appalachians.” Social Forces 39, no. 1 (1960): 41-49.

Ford, Thomas R., eds. The Southern Appalachian Region: A Survey. Lexington: University of Kentucky Press, 1962.

Gaventa, John. Power and Powerlessness: Quiescence and Rebellion in an Appalachian Valley. Urbana: University of Illinois Press, 1980.

Gerrard, Nathan L. “Churches of the Stationary Poor in Southern Appalachia.” In Appalachia: Social Context Past and Present, eds. Bruce Ergood and Bruce E. Kuhre, 274-281. Dubuque: Kendall/Hunt Publishing Co., 1976.

Gerteis, Joesph. “Political Alignment and the American Middle Class, 1974-1994.” Sociological Forum 13, no. 4 (1998): 639-666.

Glen, John M. “The War on Poverty in Appalachia: Oral History from the ‘Top Down' and the 'Bottom Up.’” Oral History Review 22, no. 1 (Summer 1995): 67-93.

Gibbons, Russell W. “Textbooks in the Hollows.” Commonweal, 6 December 1974: 231-234. 
Goode, Don J. “A Study of Values and Attitudes in a Textbook Controversy in Kanawha County, West Virginia: An Overt Act of Opposition to Schools.” Ph.D. dissertation, Michigan State University, 1984.

Goldberg, Robert A. Grassroots Resistance: Social Movements in Twentieth Century America. Belmont, CA: Wadsworth Publishing Co., 1991.

Gottfried, Paul. The Conservative Movement. New York: Twayne Publishers, 1993.

Hart, D.G. That Old Time Religion in Modern America: Evangelical Protestantism in Twentieth Century. Chicago: Ivan R. Dee, 2002.

Heineman, Kenneth. “The Silent Majority Speaks: Antiwar Protest and Backlash, 1965 1972.” Peace and Change 17, no. 4 (October 1992): 402-433.

Heinz, Donald. “The Struggle to Define America.” In The New Christian Right: Mobilization and Legitimation. eds. Robert C. Liebman and Robert Wuthnow. New York: Aldine Publishing Co., 1983.

Hennon, Charles B. and John Photiadis. “The Rural Appalachian Low-Income Male: Changing Roles in a Changing Family.” The Family Coordinator 28, no. 4 (October 1979): 608-615.

Hillocks, Jr., George. "Books and Bombs: Ideological Conflict and the Schools - a Case Study of the Kanawha County Book Protest.” School Review 86 (August 1978): 632-654.

Himmelfarb, Gertrude. One Nation, Two Cultures. New York: Alfred A. Knopf, 1999.

Himmelstein, Jerome L. To the Right: The Transformation of American Conservatism. Berkeley: University of California Press, 1990.

Hoar, William P. "Parents Revolt: When Textbooks Are Propaganda.” American Opinion (November 1974):1-8, 63-72.

Hofstadter, Richard. The Paranoid Style in American Politics and Other Essays. New York: Alfred A. Knopf, 1965.

Holland, Carl L. "A Study of the Effects of the Kanawha County Conflict on Involvement, Role, Performance, and Views of Counselors.” Ph.D. dissertation, Virginia Polytechnic Institute and State University, 1977.

Humphreys, James. “Textbook War in West Virginia.” Dissent (Spring 1976): 164-170. 
Hunter, James Davison. Culture Wars: The Struggle to Define America. New York: Basic Books, 1991.

Jameson, Fredric. “The Politics of Utopia.” New Left Review 25 (January/February 2004): 35-54.

Jenkins, Richard Jay. “Rebellion in the UMW: The Miners for Democracy, 1970-1972.” Ph.D. dissertation, Indiana University, 1974.

Jones, Loyal. “Appalachian Values.” In Appalachia: Social Context Past and Present, $3^{\text {rd }}$ Ed., eds. Bruce Ergood and Bruce E. Kuhre, 169-173. Dubuque: Kendall/Hunt Publishing Co., 1991.

Jones, Loyal. Faith and Meaning in the Southern Uplands. Urbana: University of Illinois Press, 1999.

Judkins, Bennett M. “The People’s Respirator: Coalition Building and the Black Lung Association.” In Fighting Back in Appalachia: Traditions of Resistence and Change. ed. Stephen L. Fisher.

Kaufman, Paul J. “Alice’s Wonderland; Or, School Books Are for Burning.” Appalachian Journal 2, no. 3 (Spring 1975): 162-168.

Kaufman, Paul J. “Absentee Owners of America - II: Poor Rich West Virginia” New Republic, 2 December 1972: 12-15.

Kazin, Michael. "The Grass-Roots Right: New Histories of U.S. Conservatism in the Twentieth Century.” American Historical Review 97, no. 1 (February 1992): 136-155.

Klatch, Rebecca E. Women of the New Right. Philadelphia: Temple University Press, 1987.

Klien, Joe. “The Ministry of George C. Wallace.” Rolling Stone, 24 October 1974, 32-41.

Leege, David C. And Lyman A. Kellstedt. "Religious Worldviews and Political Philosophies: Capturing Theory in the Grand Manner through Empirical Data.” In Rediscovering the Religious Factor in American Politics. eds. David C. Leege and Lyman A. Kellsedt, 216231. Armonk, NY: M.E. Sharpe, 1993.

Leonard, Bill J., ed. Christianity in Appalachia: Profiles in Regional Pluralism. Knoxville: University of Tennessee Press, 1999.

Lewis, Helen Matthews, Linda Johnson, and Donald Askins, eds. Colonialism in Modern America: The Appalachian Case. Boone, NC: The Appalachian Consortium Press, 1978. 
Lewis, Oscar. “The Culture of Poverty.” In On Understanding Poverty; Perspectives from the Social Sciences, ed. Daniel P. Moynihan. New York: Basic Books, 1969.

Lewis, Ronald L. and Dwight B. Billings. “Appalachian Culture and Economic Development: A Retrospective View on the Theory and Literature.” Journal of Appalachian Studies 3, no. 1 (1997): 3-40.

Liebman, Robert C. "Making of the New Christian Right.” In The New Christian Right: Mobilization and Legitimation. eds. Robert C. Liebman and Robert Wuthnow.

Liebman, Robert C. and Robert Wuthnow, eds. The New Christian Right: Mobilization and Legitimation. New York: Aldine Publishing Co., 1983.

Lienesch, Michael. "Right-Wing Religion: Christian Conservatism as a Political Movement." Political Science Quarterly 97, no. 3 (Fall 1982): 403-425.

Lippy, Charles H. “Popular Religiosity in Central Appalachia.” In Christianity in Appalachia: Profiles in Regional Pluralism. ed. Bill J. Leonard.

Lipset, Martin and Earl Raab. The Politics of Unreason: Right-Wing Extremism in America, 1790-1977. Chicago: University of Chicago Press, 1978.

Litt, Edgar. “The Politics of a Cultural Minority.” In Electoral Process. eds. M. Kent Jennings and L. Harmon Zeigler, 105-121. Englewood Cliffs: Prentice-Hall, 1996.

Manthe, Karen. "Rural Youth - Focus of AEL.” Appalachian Advance 5, no. 2 (November 1970): 2-4 \& 32.

Martin, William. With God on Our Side: The Rise of the Religious Right in America. New York Broadway Books, 1996.

Marty, Martin E. Religion and Republic: The American Circumstance. Boston: Beacon Press, 1987.

Marty, Martin E. "Religion in America since Mid-century.” Daedulus 111, no. 1 (Winter 1982): 149-163.

Marty, Martin E. The Protestant Voice in American Pluralism. Athens, GA: University of Georgia Press, 2004.

Marty, Martin E. The Public Church: Mainline-Evangelical-Catholic. New York: Crossroad Publishing Co., 1981. 
Mason, Carol. “An American Conflict: Representing the 1974 Kanawha County Textbook Controversy.” Appalachian Journal 32, no. 3 (Spring 2005): 352-377.

Mason, Carol. “Textual Reproduction of Ethnicity in the Kanawha Valley: The 1974 Textbook Controversy Revisited.” Huntington: Rockefeller Foundation and the Center for the Study of Ethnicity and Gender and Marshall University, February 2003.

McCauley, Deborah Vansau. Appalachian Mountain Religion: A History. Urbana: University of Illinois Press, 1995.

McGirr, Lisa. Suburban Warriors: The Origins of the New American Right. Princeton: Princeton University Press, 2001.

McNearney, Clayton L. “The Kanawha County Textbook Controversy.” Religious Education LXX, no. 5 (September/October 1975): 519-540.

McVeigh, Rory and Christian Smith. "Who Protests in America: An Analysis of Three Political Alternatives - Inaction, Institutionalized Politics, or Protest.” Sociological Forum 14, no. 4 (1999): 685-702.

Mertes, Tom. “A Republican Proletariat.” New Left Review 30 (November/December 2004): 3747.

Moffett, James. Storm in the Mountains: A Case Study of Censorship, Conflict, and Consciousness. Carbondale: Southern Illinois UP, 1988.

Mosier, Richard D. Making the American Mind: Social and Moral Ideas in the McGuffey Readers. New York: King’s Crown Press, 1947.

Nesius, Ernest J. “The Role of the Church in Appalachia.” In Proceedings. Commission on Religion in Appalachia, 1-13. Knoxville: Appal, Inc., 18 October 1966.

Omi, Michael and Howard Winant. Racial Formation in the United States: From the 1960s to the 1990s, $2^{\text {nd }}$ Ed. New York: Routledge, 1994.

Page, Ann L. and Donald A. Clelland. "The Kanawha County Textbook Controversy: A Study of the Politics of Life Style Concern.” Social Forces 57, no. 1 (September 1978): 265-281.

Parker, Franklin. The Battle of the Books: Kanawha County. Bloomington: Phi Delta Kappa Educational Foundation, 1975. 
Peele, Gillian. Revival and Reaction: The Right in Contemporary America. Oxford: Clarendon Press, 1984.

Phillips, Kevin P. The Emerging Republican Majority. New Rochelle: Arlington House: 1969.

Photiadis, John D., ed. Religion in Appalachia: Theological, Social, and Psychological Dimensions and Correlates. Morgantown: West Virginia University, 1978.

Photidas, John D. And Harry K. Schwarzweller, eds. Change in Rural Appalachia: Implications for Action Programs. Philadelphia: University of Pennsylvania Press, 1970.

Porterfield, Amanda. The Transformation of American Religion: The Story of a Late-Twentieth Century Awakening. New York: Oxford University Press, 2001.

Reagan, Ronald. “Unforgettable John Wayne.” Reader’s Digest, October 1979: 114-119.

Ribuffo, Leo P. "Why Is There So Much Conservatism in the United State and Why Do So Few Historians Know Anything about it?” American Historical Review 99, no. 2 (April 1994): 438-449.

Rieder, Jonathan. “The Rise of the Silent Majority.” In Rise and Fall of New Deal Order, 1930-1980, eds. Steve Fraser and Gary Gerstle. Princeton: Princeton UP, 1989.

Rifkin, Jeremy with Ted Howard. The Emerging Order: God in the Age of Scarcity. New York: G.P. Putnam’s Sons, 1979.

Rogin, Michael. "Wallace and the Middle Class: The White Backlash in Wisconsin.” The Public Opinion Quarterly 30, no. 1 (Spring 1966): 98-108.

Saloma, John S., III. Ominous Politics: The New Conservative Labyrinth. New York: Hill and Wang, 1984.

Schwarzweller, Harry K. and James S. Brown. "Education as a Cultural Bridge between Appalachian Kentucky and the Great Society.” In Change in Rural Appalachia: Implications for Action Programs. eds. John D. Photiadis and Harry K. Schwarzweller.

Seltzer, Curtis. “The Media vs. Appalachia: A Case Study.” Mountain Review 3, no. 2 (May 1976): 10-11.

Seltzer, Curtis. “West Virginia Book War: A Confusion of Goals.” Nation, 2 November 1974: 430-435.

Seymour, Dorothy Z. “Black Children, Black Speech.” Commonweal, 19 November 1971: 175- 
178.

Shannon, George W. “Pro-Integration Textbooks Opposed.” The Citizen, February 1975: 4-11 \& 31.

Sharp, Elaine B. Culture Wars and Local Politics. Lawrence: University Press of Kansas, 1999.

Smith, Rex. "Rex Smith Cites Need For Long-Range Plan.” Appalachian Advance 1, no. 1 (October 1966): 25 \& 32.

Sovine, Melanie L. "Studying Religious Belief Systems in Their Social Historical Context.” In Appalachia and America: Autonomy and Regional Dependence. ed. Allen Batteau, 4867. Lexington: University of Kentucky Press, 1983.

Thompson, Hunter S. Fear and Loathing on the Campaign Trail `72, Reissue Edition. New York: Warner Books, 1985.

Trillin, Calvin. “U.S. Journal: Kanawha County, West Virginia.” New Yorker, 30 September 1974: 119-127.

Utter, Glenn H. And James L. True. Conservative Christians and Political Participation. Santa Barbara: ABC-CLIO, Inc., 2004.

Wald, Kenneth D. “The Religious Dimension of American Anti-Communism.” Journal of Church and State 36, no. 3 (Summer 1994).

Walls, David S. and John B. Stephenson, eds. Appalachia in the Sixties: Decade of Reawakening. Lexington: University of Kentucky Press, 1972.

Welch, Janet Boggess. "Uneven Ground: Cultural Values, Moral Standards, and Religiosity in the Heart of Appalachia.” In Christianity in Appalachia: Profiles in Regional Pluralism. ed. by Bill J. Leonard.

Weller, Jack E. Yesterday’s People: Life in Contemporary Appalachia. Lexington: University of Kentucky Press, 1966.

Whitaker, Robert E., ed. The New Right Papers. New York: St. Martin’s Press, 1982.

Whitaker, Robert E. Whitaker's Law on Public Financing. January 15, 2000 [on-line]. <http://www.whitakeronline.org/011500.htm> [April 11, 2005].

White, Clinton. “The Day the King’s Son Died (How to be Born Again).” [Pamphlet]. Lancaster, NH: Gospel Messenger Service, Year Unknown. 
Wilcox, Clyde. God's Warriors: The Christian Right in Twentieth Century America. Baltimore: John Hopkins University Press, 1992.

Wilcox, Clyde. "Popular Backing for the Old Christian Right: Explaining Support for the Christian Anti-Communist Crusade.” Journal of Social History 21, no. 1 (Fall 1987).

Wilkin, F. David. “The Kanawha County, West Virginia, Textbook Issue: Social Policy in Dispute.” Paper, Harvard University, 6 January 1975.

With God on Their Side - Episode Two: The Zeal of Thy House. VHS. Directed by Calvin Skaggs. Lumiere Productions.

Wood, Richard L. "Religious Culture and Political Action.” Sociological Theory 17, no. 3 (November 1999): 307-332.

Wuthnow, Robert. "Political Rebirth of American Evangelicals.” In The New Christian Right: Mobilization and Legitimation. eds. Robert C. Liebman and Robert Wuthnow.

Yohn, Susan M. "Will the Real Conservative Please Stand Up? or, The Pitfalls Involved in Examining Ideological Sympathies: A Comment on Alan Brinkley's 'Problem of American Conservatism.”” American Historical Review 99, no. 2 (April 1994): 430-437. 